\title{
"Here There Is No Plague": The Ideology and Phenomenology of AIDS in Gay Literature
}

\author{
Michael Alan Buso
}

Follow this and additional works at: https://researchrepository.wvu.edu/etd

\section{Recommended Citation}

Buso, Michael Alan, "'Here There Is No Plague": The Ideology and Phenomenology of AIDS in Gay Literature" (2017). Graduate Theses, Dissertations, and Problem Reports. 5291.

https://researchrepository.wvu.edu/etd/5291

This Dissertation is protected by copyright and/or related rights. It has been brought to you by the The Research Repository @ WVU with permission from the rights-holder(s). You are free to use this Dissertation in any way that is permitted by the copyright and related rights legislation that applies to your use. For other uses you must obtain permission from the rights-holder(s) directly, unless additional rights are indicated by a Creative Commons license in the record and/ or on the work itself. This Dissertation has been accepted for inclusion in WVU Graduate Theses, Dissertations, and Problem Reports collection by an authorized administrator of The Research Repository @ WVU.

For more information, please contact researchrepository@mail.wvu.edu. 
"Here There Is No Plague":

The Ideology and Phenomenology of AIDS in Gay Literature

\author{
Michael Alan Buso
}

Dissertation submitted to the Eberly College of Arts and Sciences at West Virginia University in partial fulfillment of the requirements for the degree of

\author{
Doctor of Philosophy \\ in English
Dennis Allen, Ph.D., Chair
Ryan Claycomb, Ph.D.
Michael Germana, Ph.D.
Melissa Latimer, Ph.D.
Kathleen Ryan, Ph.D.

Department of English

Morgantown, West Virginia

2017

Keywords: Ideology, Phenomenology, AIDS, Gay, Queer Studies, American Literature Copyright 2017 Michael Buso 


\section{ABSTRACT \\ "Here There Is No Plague": \\ The Ideology and Phenomenology of AIDS in Gay Literature}

Michael Alan Buso

This project considers the social movements, historical memory, and politics of health to trace the way the literature of the AIDS epidemic both documents and discloses the lived experiences of a community struggling in the midst of an epidemic. It focuses on the literature of AIDS, analyzing the underlying ideologies of AIDS and articulating a phenomenology of AIDS that goes beyond the feminist or queer ones already considered in current scholarship. I argue that the literature of AIDS reflects various ideological fantasies about AIDS that, depending on political preconceptions and ontologies of identity, must, out of necessity, exclude certain ideas in order for the fantasy to work. Through both Larry Kramer's The Normal Heart and Tony Kushner's Angels in America, I analyze how the ideological forces at work within the gay community are represented in the literature of the 1980s and 90s. My focus is on how, in the early days of the epidemic, these plays presented a specific ideological fantasy about AIDS, and my analysis identifies what things must be excluded or overlooked in order for the fantasies to properly function. Despite the extensive critical work focusing on the AIDS epidemic, there has not been a scholarly work that constructs a phenomenology of AIDS. And so, I move beyond current feminist and queer approaches to phenomenology to use Andrew Holleran's novel The Beauty of Men and collection of essays Ground Zero to develop a phenomenology of AIDS. I argue that Holleran's texts are less concerned with the political, historical, and ideological structures that brought about the AIDS epidemic and more concerned with how gay men lived within the disease - how they formed social/physical attachments to both people and places, and how their sensory experiences of the epidemic created their individual and collective subjectivities. The shared experience of AIDS becomes the foundation for the reemerging/restructuring gay subculture; in a phenomenological sense, the community gains an awareness/consciousness of who it is by examining more carefully what it no longer is. I conclude with an examination of $21^{\text {st }}$ century young adult gay fiction - specifically Boy Meets Boy by David Levithan and Hero by Perry Moore - and how they paint rosy portraitures of gay life beyond the coming out stage to the neglect of a complex sexuality that continuously redefines a queer individual's place within the greater social, political, and cultural structure. Yet the presence - the memory — of AIDS looms over these texts, and the novels still contain the trace of what AIDS was/did to the gay community that came before them. By creating worlds without AIDS, these novels attempt to create a new version of a "gay fantasia," one that counters the stark realities and oppressive ideological structures of the gay fantasia presented by Kushner in Angels in America. 


\section{Acknowledgements}

I have to begin by thanking my dissertation chair and overall advisor, Dennis Allen, for the countless hours of guidance and assistance with this project. He has made me a better scholar, a better thinker, and this project all the better. The other members of my committee, Katy Ryan, Ryan Claycomb, Michael Germana, and Melissa Latimer, have all offered invaluable assistance with this dissertation and the many steps along the way, and I am so grateful for everything they have done. And though he was not on my committee, Lowell Duckert provided sound advice and a helpful point in the right direction, and I am thankful for his time and knowledge.

I also want to thank Larry Kramer, Tony Kushner, Andrew Holleran, Perry Moore, and David Levithan, for writing such excellent texts worthy of study. Though this project took a long time to complete, I never tired of reading their words.

My family, especially my mom and my sister, have been so supportive of me throughout the Ph.D. process, and I thank them for their encouragement and love. And I am so thankful for the support and love of the Bishop men, Mark, Noah, and Maddox.

I have made a lot of wonderful new friends in my seven years here at WVU. There's too many to name all of them, but I especially appreciate the friendships of Mark and Mikenna (during our long summer of coursework together), Teresa, Andrea, Jessica, Keith, Gregory, Katie, and of course, William (my groovy office-mate).

Dr. Yvonne Hammond has been a wonderful friend, office-mate, confidant, and ally. Our long talks and our travels all over this crazy country of ours have meant the world to me, and I appreciate your sage and considerate thoughts and advice.

And lastly, all my love and thanks to my husband Trey, who came with me many years ago on this adventure, and has been my rock throughout it all. I cannot imagine doing this without him, and there is no one I would rather spend my life with. 
Introduction

"Ordinary Sexual Intercourse": Ideological Fantasies of Homosexuality and AIDS

Chapter One

“A Social Death": The Ideology of the AIDS Epidemic in Larry Kramer's

The Normal Heart

Chapter Two

"Everybody's Got to Love Something": AIDS Fantasies, Both Prophetic and

Ideological, in Tony Kushner's Angels in America

Chapter Three

"When No One Knew the Way Out": Developing a Phenomenology of AIDS

Through the Writings of Andrew Holleran

Chapter Four

"If Anybody Notices, Nobody Cares": The Trace of AIDS in David Levithan's Boy Meets Boy and Perry Moore's Hero

Conclusion

"The Legacy of AIDS": The Paradox of Living With and Ending an Epidemic 


\section{Introduction \\ "Ordinary Sexual Intercourse": Ideological Fantasies of Homosexuality and AIDS}

"If it is an epidemic, then what happens to all this?" Hank pointed to the street. "Everything we've gained has come out of this neighborhood and the others we have built across the country.

We lose our political power. We lose our culture, our safety." (Jones 198)

In January of 1988, as the mainstream American media was at last writing more and more about the AIDS epidemic, Cosmopolitan magazine published an article by Dr. Robert Gould titled "Reassuring News About AIDS: A Doctor Tells Why You May Not Be At Risk." Gould, a clinical professor of psychiatry and obstetrics/gynecology at New York Medical College, and the chairman of the committee on gay and lesbian issues for the New York County branch of the American Psychiatric Association, told his readers that as heterosexual American women they had nothing to worry about when it came to AIDS. "There is almost no danger," Gould wrote to Cosmo's readers, "of contracting AIDS through ordinary sexual intercourse," an act that he precisely and narrowly defines as "penile penetration of a well-lubricated vagina" (146, emphasis his). Rough sex, he cautions, or the way "many men in Africa take their women in a brutal way" that might cause vaginal lacerations, is a "marked difference[] from the way [sex] is usually practiced in the United States" (147). Anal sex and IV drug use, he cautioned, are the only confirmed ways of transmitting the virus, even as anal sex, according to Gould, was "now becoming relatively rare even among homosexuals" (204). Gould's assumptions posit an imaginary existence in which heterosexual American couples (and more specifically, those who 
read Cosmopolitan) never engage in rough vaginal or anal sex, and where all "normal" American women only engage in penetrative sex when their vaginas are well-lubricated. ${ }^{1}$ These assumptions form the basis of a heteronormative ideology, what Louis Althusser calls "the imaginary relationship of individuals to their real conditions of existence" (256), that ignores the actual relationship of heterosexual American women to the world in which they live in favor of believing a false construct that relies on faulty logic and a sense of "othering."

Gould's constant positioning of the gay community as different, apart from the norm (“out-groups" as he says), even foreign (the way African sex is), reinforces the heteronormative public's false consciousness that gays are deviant outsiders, engaging in unnatural sexual practices. "Your own body," and specifically "a healthy vagina," Gould tells his readers, "is the best protection against injury. Nature has arranged this so that sex will feel good and be good for you" (146, emphasis his). Gould goes on to contrast anal sex as high-risk and, unlike vaginal intercourse, "often traumatic" (147). Moreover, as Gould wraps up his argument with a plea that his heterosexual readers not allow AIDS to "kill our sexual selves," he constantly uses "we" and "us" to align himself with his readers as those who engage in natural, normal vaginal sex and apart from those who do not, while un-ironically stating that sexual enlightenment allows them "to continue to behave as fully sexual beings" the way "God and nature made us" (204). Gould doubles-down when it comes to African sex and homosexuality—not only are both foreign, they

\footnotetext{
1 “Anal sex as a symbol of homosexual desire becomes an obsessive topic of interest in discussions of safe sex," Cindy Patton argues in Inventing AIDS. "The conviction that anal sex is somehow at the root of AIDS enables heterosexuals to avoid thinking about making changes in their practice of vaginal intercourse. In addition, the insistence that AIDS is somehow a mark of perversion transforms infected persons into 'queers,' regardless of their exposure route, a phenomenon I have called the 'queer paradigm"' (117).
} 
are probably the same thing. "It has been said that in Africa heterosexual intercourse is a documented mode of transmission," Gould begins. However, he recommends such a medical report "be viewed with strong skepticism" due to "cultural differences" (147). These differences, for Gould, stem from the way that "homosexuality, although commonplace among their people, was not talked about or even acknowledged," and so he concludes that African heterosexual transmissions are more probably the result of lying homosexual Africans engaging in anal sex (147). In these senses, the homosexual is created as a subject, not from any condition of reality, but rather in an imaginary state that best serves the needs of the dominant (and here, heteronormative and homophobic) culture. The ideology that surrounds AIDS is less about the actions of men (hetero- or homo-) and more concerned with the (imaginary) possibilities of such actions and how such movements support, challenge, restrict, or uphold the existing structures. Moreover, Gould expands this ideology by blaming public misperceptions of AIDS transmission on researchers who "will receive larger grants and be funded more readily if AIDS is thought not to be larger restricted to the out-groups" (147). Many gay organizations, Gould argues, also benefited from the perception that AIDS is not a gay disease as such a perception is a "burden these organizations would otherwise have to bear" (147). Gould frames this in such a way that perceptions are the burden, rather than the harsh, stark reality of AIDS killing off the gay community en masse. He reinforces his assault on perceptions (rather than reality) when he criticizes health officials for promoting the "irrational fear that AIDS is spreading or soon will spread rampantly through heterosexual intercourse" and arguing that "this killing of our sexual selves ... may prove more destructive in the long run than the AIDS virus itself" (204). Within the gay community itself, conflicting ideologies of AIDS developed precisely because gay men struggled with how to process/address these imaginary possibilities. If liberation helped bring the 
gay community into the mainstream, AIDS became the material confirmation of the gay subculture's outsider status.

Throughout this dissertation I invoke the phrase "gay community" as a collective noun/concept through which members of this identity category can establish themselves as a coherent, cohesive subculture (although the boundaries of who is included are porous, just as our understandings of who participates in this community change over time). The intent is not to create or promote a false binary between hetero- and homosexuality, nor define or insist on any essential form of either category. Rather, the generalness of the terminology allows for an openness of meaning and inclusion instead of more limiting or exclusionary phrases. All communities are, as Benedict Anderson writes, imagined and are "distinguished ... by the style in which they are imagined" (6). There are no communities that are not imagined, he argues, and even small, close-knit groups still create networks and structures of community. The gay community, then, exists only as a larger imaginary construct, constantly being recreated and redefined by those within and those without it. And in many ways, the white gay men who write the texts analyzed in this dissertation have imagined their own gay communities, centered around their specific life experiences in specific places and times, and often ignoring or overlooking the multitude of other possible ways in which the gay community might equally be constructed. As a result, these constructions of the gay community might only acknowledge or offer passing notice of other members within that larger community while failing to give space to the voices and experiences of lesbians, bisexuals, transgender, minorities, or even gay men not centered in New York and San Francisco.

As the gay community navigated the AIDS epidemic, and as it attempted to leave that epidemic behind, it could not repress the impact of AIDS and the loss it brought. I argue that 
instead, particularly in novels that seemingly ignored the AIDS epidemic or looked to more idyllic times, those ideologies that shaped the gay community throughout the epidemic return as traces. I argue that AIDS, having been repressed, becomes the unconscious of the increasingly heteronormative gay community and that the advent and ensuing history of AIDS uncovers the variable and complex imaginary relations that heterosexual culture has to homosexuals and that homosexuals have toward themselves. The heterosexual community has created an imaginary relationship with a gay community in the throes of the AIDS epidemic; by telling themselves that gross, rough, dirty sex (including acts of bondage, sadomasochism, or even anal) belongs to some other group outside of mainstream American society, heterosexual America convinces itself that since they do not participate in such risky and gross sex acts they are not susceptible to AIDS. Yet the gay community also maintains conflicting ideologies founded on such imaginary relations: arguments developed over the importance of sexual freedom as social and individual identity, and its historical importance/relevance; sexual liberation served as a cornerstone of the gay civil rights movement in the decade following the Stonewall Riots and many within the gay community struggling to survive during the AIDS epidemic believed that if they were to lose their ability to engage in open and liberal sexual behaviors they would lose not only who they were as a community but also all the progress towards civil and social justice they had fought so hard to attain.

What follows, then, is first an outline of the methodological choices I have made for this dissertation, followed by a critical discussion of the historical events, as well as the gay literature generated in relation to those events, that illustrate prior political and ideological interventions into the cultural discourse surrounding homosexuality and the AIDS epidemic. This discussion attempts to present and critique the different ideological forces at work (both within and without 
the gay community, including radical and conservative queer points-of-view) without taking sides or declaring any one ideology more preferable (or correct) than another. In this dissertation I argue that AIDS is a fragment of an unassimilable Real and the history and cultural discourse of AIDS literature is the history of various ideological and phenomenological standpoints for providing it with a meaning. For Larry Kramer, the AIDS epidemic reinforced his own ideological reading of the morality of monogamy, while Tony Kushner works to reconstruct the predominant ideologies surrounding AIDS into oppositional ideologies that use queer progress as a means for reconsidering the relationship between the gay community and sexual freedom. Andrew Holleran appropriates the objects of the AIDS epidemic in order to develop his own phenomenological apparatus that explores the realities of bodies living in the time of AIDS. And finally, the novels of David Levithan and Perry Moore, while seemingly ignoring AIDS, help reveal how the ideologies and phenomenologies surrounding the epidemic have left an unrelenting impact on the gay community and despite the authors' attempts to construct a world without AIDS, traces of the virus still remain.

\section{METHODOLOGY}

Taken as a whole, this dissertation looks at this cultural shift through the lens of queer time; once it was the inescapability of AIDS that necessitated the gay community conceive of different alternative temporalities. It is in the present moment - a time after the AIDS epidemic “ended" 2 - that the plague, having been repressed in gay culture and literature, returns as a trace.

\footnotetext{
${ }^{2}$ Victory, or at least victory for white gay men in America, was declared resolutely in Andrew Sullivan's 1996 essay "When Plagues End" (reprinted in his collection of essays Love Undetectable) as the arrival of protease inhibitors marked a substantial shift in AIDS-related discourse. In it, Sullivan argues, "a diagnosis of H.I.V. infection is not just different in degree
} 
And though it is different in form and intent, the present community still operates under its own variation of queer time where the literature containing the trace of AIDS looks both forward and back in time - those shifts playing with their own internal narrative time as well as those changes outside of the texts themselves.

The trace of AIDS is displaced, and found in its own absences and omissions. This displacement is bonded directly to its cultural resistance against chrononormativity. Husserl's phenomenology of temporality focuses on retentions and protentions; along those lines the trace I am addressing here looks forward and back, forgetting the "now" in order to perceive where we are going and from where we came. As such, a phenomenological analysis of these texts will expand our understanding of how and where the trace of AIDS takes hold and is displaced to. Moments of loss and absence, including though not limited to representations of the loss of innocence that accompanies sexuality, are simulacra - copies of copies of copies without an original referent - that hold the place of AIDS while still representing all its effects on the gay community. This dissertation performs an ideological critique on specific, representative texts that illustrate the shifting cultural approaches to AIDS over the course of the past three decades. A queer theoretical approach to these literary texts allows me to play with queer time and issues of temporality in both content and structure.

In order to refine this approach even further, this dissertation focuses primarily on the community and literature of primarily white gay men, which is to say that the authors of the primary texts examined all self-identify as gay (or queer), and the main characters within each

today than, say, five years ago. It is different in kind. It no longer signifies death. It merely signifies illness" (8). Sullivan performs his own form of ideological erasure to argue for an ending to an epidemic that would continue on to infect and kill millions, most notably in African and Black American communities. 
work are also gay men. This selection allows for a closer analysis of the specific ideologies and phenomenologies that surrounded and impacted gay men throughout the AIDS epidemic and differentiates those ideologies from ones that impacted the lesbian, transgender, and/or heterosexual communities. As Gregory Woods argues, "the concept of 'gay literature' has to be seen as a moveable feast. It often seems to exist in the spaces between texts, shaped by debate between pro- and anti-homosexual historians and critics, continually reconstituted by new theoretical conceptions of both literature and sexuality" (16). My interest here is multi-faceted, focusing on exploring the literature of gay men, but also in doing critical analysis of gay characters as written by gay men, and reconsidering works of modern/recent gay literature that have gone primarily unnoticed or overlooked. My goal by making such distinctions involving the sexual identities of the authors is not to create some sort of strict criteria for what may or may not be considered gay literature, but rather to expand and contest existing borders of literary analysis and, ideally, give attention and emphasis to authors who may otherwise be generally unrecognized in literary and academic analysis. Nor do I wish to get bogged down in semantic (and pedantic) arguments over what constitutes gay literature, or the decision to use gay as an adjective for literature at all.

Anytime a critical work focuses solely on the writings of white men some further discussion/explanation is required, and this dissertation is no different. AIDS, the epidemic itself, but also the literature and cultural works surrounding it, is not only about white gay men. And so, to put it plainly, women and minorities are not simply sub-groups to be tacked onto critical AIDS studies as though they were tangential to some other primary area of study. As the ACT UP / NY Women and AIDS Book Group wrote in Women, AIDS, and Activism, AIDS studies cannot simply lump women in with men: "Different questions need to be asked, in order to establish 
future research priorities, to identify women's treatment issues, to make demands for change in the health care system, and to overcome the barriers to fighting HIV infection" (vii). And so, while there are many extensive and complex works that focus specifically on women and AIDS, ${ }^{3}$ this dissertation is not one of them.

Similar moves need to be made when talking about race and AIDS. The AIDS epidemic has had a disastrous effect on Black American and African peoples and cultures. The medical communities special at-risk "Four H" group (homosexuals, Haitians, hemophiliacs, and heroin injectors) did little to shift the public viewpoint that AIDS was a gay disease (Andriote 58). Rather than bringing attention and help to those in need, identifying other at-risk groups did little except further emphasize how apart from, and threatening to, mainstream "normal" America they were. Culture and media did little to combat the othering that occurred; Cindy Patton argued how even from the early years of the epidemic, progress to end AIDS in Africa was derailed by the "pre-existing Western image of a wasting continent peopled by victim-bodies," and that instead of highlighting medical successes, western media chose to "portray Africa as romantic tragedy in which poverty is so total, so basic, that there is nothing to be done to save the continent" (Inventing 83, emphasis hers).

Over the past 15 years, the white gay community has collectively abandoned AIDS discourse in favor of more palatable (and hetero-friendly) pushes for equality in marriage, adoption, and employment, essentially ignoring the devastating effects AIDS is having in Black America and Africa. Writing in 2014, Adam M. Geary's Antiblack Racism and the AIDS

${ }^{3}$ Consider Patti Lather and Chris Smithies' Troubling the Angels: Women Living with HIV/AIDS (1997), Vicki Tallis' Feminisms, HIV and AIDS (2012), Anika Wilson's Folklore, Gender, and AIDS in Malawi (2013), and Nancy Stoller's Lessons from the Damned: Queers, Whores, and Junkies Respond to AIDS (1998) to start. 
Epidemic opens with the attention-grabbing declaration, "The color of AIDS in America is black" (1). The Centers for Disease Control (CDC) reported that when it came to the number of Blacks / African Americans, the "Estimated Number of Persons with Diagnosed HIV Infection Ever Classified as Stage 3 (AIDS)" in 2013 was double that of White Americans (13,172 Black to 6,759 White diagnosed). Moreover, when this number is calculated from the start of the epidemic, more Blacks have been diagnosed with AIDS than Whites (497,267 Black to 436,557 White). ${ }^{4}$ Geary argues that, when it comes to the discourse surrounding AIDS in Black America and Africa, "As long as the concept of risk is contained within the discourse of queers, there need be no investigation into the structured relations of inequality and vulnerability, like racism, poverty, sexism, and state violence, that organize and distribute social risks, including the risk of HIV infection" (18). Several excellent texts further this work, ${ }^{5}$ including Geary's own. There are women and persons of color in the texts addressed in this dissertation, but the main characters are gay white men. ${ }^{6}$ The selection of texts in this dissertation allows me to concentrate on one of many sites of experience and to acknowledge the ways that the imaginative acts of gay white

\footnotetext{
${ }^{4}$ Of course, these numbers are extremely low compared to those coming out of Africa, where the UNAIDS organization reported "In sub-Saharan Africa, 1.1 million [1.0 million - 1.3 million] people died of AIDS-related causes in 2013" (2).

5 Jacob Levenson's The Secret Epidemic: The Story of AIDS and Black America (2005), Cathy Cohen's The Boundaries of Blackness: AIDS and the Breakdown of Black Politics (1999), and Pamela Payne Foster's "Is there a Balm in Black America?": Perspectives on HIV/AIDS in the African American Community (2007) to name just a few.

${ }^{6}$ Nor can this dissertation properly take into account the intersections of race and gender as analyzed in, for example, Quinn M. Gentry's Black Women's Risk for HIV (2007) or Linda K. Fuller's African Women's Unique Vulnerabilities to HIV/AIDS (2008).
} 
men have had real consequences when it comes to how AIDS is understood and treated, both inside and outside the gay community.

\section{OUTSIDERS AND SEX PERVERTS}

Even though gay men generated many of the cultural artifacts of the communities in which they lived, they were still marked as outsiders, as deviants who threatened the heteronormative religious, political, and social institutions. "The AIDS epidemic," argues Woods, "has not radically altered the ways in which homosexual men are perceived by the rest of society, but it has shifted perceptions of us further in the directions of two tendencies which were already apparent before the epidemic began" (369). According to Woods, these two tendencies are the "self-destructive pervert" whose sex acts challenge God and Nature and "the diseased victim" (370). Gay men are then constituted through this imaginary relationship with the real world; their actual status in regards to HIV, AIDS, or other sexually transmitted diseases is irrelevant because their positions as outsiders have interpellated them as diseased and perverted. This imaginary construct is identified by Woods as "the myth of the tragic queer" (370), important not because it reinforces the gay=death equation but because it invokes and reinstills the prevalent heteronormative belief that homosexuals are not like the rest of the society but rather are hopelessly destined for tragedy in a way heterosexuals never will be.

When Representative Arthur Miller of Nebraska spoke before the United States House of Representatives in 1950, he railed against the infiltration of the Federal Government by homosexuals, whom he called "sex perverts" and "undesirable characters" while offering a long list of sexual terms/acts (such as "necrophalia, fettichism, pygmalionism, fellatios, cunnilinguist, sodomatic, pederasty, saphism, sadism, and masochist" [sic]) that appeared in "the vocabulary of 
the homosexual" (Cong. Rec.). For Miller, the State Department's purge of over 90 homosexuals was not decisive enough; too many of them were possibly hired by other government offices and so the potential threat posed by homosexuals had not been resolved, merely spread out and shifted to other, still conceivably damaging, roles within the Federal Government. Standing before Congress, Miller presented homosexuals as more than just sexual deviants; rather they were untrustworthy outsiders representing foreign ideas that threatened not just the social culture of America but also its national security:

I sometimes wonder how many of these homosexuals have had a part in shaping our foreign policy. ... It is a known fact that homosexuality goes back to the Orientals, lone [sic] before the time of Confucius ... Perhaps if all the facts were known these same homosexuals have been used by the Communists. (Cong. Rec.)

Of course, the threat is not really the placement/employment of individual, specific homosexuals within the upper echelons of government, but rather the revelation that (due to their ability to "pass" as heterosexuals while operating from within the sexual "closet") homosexuals operate as part of a mysterious and dangerous underworld, much like communists and other radicals. Miller's statements reinforce a collective imaginary that positions homosexuals as apart from both Congress (Miller's detailed explanations of homosexuality seems to postulate a Congress devoid of homosexual members or staffers) and the national community (they are threats to “our” foreign policy). These connections promoted the imaginary ideological fantasy that homosexuals are in essence spies that pass amongst the general "normal" population. Linking sexual deviants with the threat of communism was all the rage in post-war America. Following World War Two, many states enacted sex psychopath laws that allowed homosexuals to be imprisoned indefinitely. As Allan Bérubé recounts, "The media and government propaganda 
associated homosexuals and other 'sex psychopaths' with communists as the most dangerous nonconformists-invisible enemies who could live next door and who threatened the security and safety of children, women, the family, and the nation" (Coming Out 258). Bérubé's placement of the threat as one "who could live next door" recognizes the fear that accompanied the threat of homosexuality as an anxiety over collapsing social boundaries and structures and a manifestation of the post-war fears.

Miller's Congressional ranting ignored the actual relationships between homosexuals and the government for whom they worked in favor of crafting an imaginary narrative that allowed the heteronormative hegemony to make the homosexual community/identity the focal point of cultural struggles over collapsing and unstable identity categories. Through his statements to Congress, Miller seeks to dehumanize homosexuals as part of this ideological agenda: "You must know what a homosexual is. It is amazing that in the Capital City of Washington we are plagued with such a large group of those individuals" (Cong. Rec.). Miller's use of plague metaphor equates homosexuals to the silent, unseen viruses that threaten the health and wellbeing of society. A few moments later in the same Congressional record, Cliff Clevenger of Ohio equates homosexuality with "such loath some diseases as gonorrhea and cancer" (Cong. Rec.). Like cancerous cells and plague viruses, what truly concerns Miller and Clevenger is homosexuality's ability to disturb and destabilize the social structures and boundaries, revealing such constructs to be inherently porous but essentially illusory. It is in the interest of the hegemonic social structures, rather than the best interests of a burgeoning queer community, to discover and properly label homosexuals in its midst; "Gayness is not," as Alan Sinfield argues, "a property of individuals, but a mode of categorizing ... Trying to decide who the real 
homosexuals are, therefore, is to join the ideological circus, not to gain a vantage on it" (Cultural 71).

Painting homosexuals as threats to American society took place on both a political level as well as a moral one (and for government service, such qualitative distinctions were rarely made). David K. Johnson, writing about the military and government's use of the euphemism "security risk" to refer to homosexuals, explains how "Persons who might divulge secret information, because they were either careless or coerced, were labeled security risks" (7). Security risks differed from questions of loyalty because issues of security risks "involved behaviors or association that might lead one inadvertently or unwillingly to betray secrets in the future" (8). Homosexuality was, then, a moral defect, often lumped together with those who drink too much and those who talk too much. Although the alcoholic and the loquacious were also considered threats, homosexuality "was the only one of the three to be illegal, thereby automatically enlisting every police force in the nation in its enforcement" (8). Sinfield, analyzing the presence of homosexuality and political criticism in poetry, observed how overt references to homosexuality were flagged and censored; yet covert criticisms of the government remained embedded in the text. As Sinfield argues, "Dissidence is least threatening when it can be seen to be respecting boundaries" (Cultural 64). This, then, is the problem those in power have both with homosexuality in literature and culture as well as with homosexuals themselves occupying high-level government positions. Homosexuals, and homosexuality writ large, betrays the boundaries and borders of secrecy that public power so often relies on, reminding those engaged in clandestine games that such demarcations of identity and power are tenuous at best and non-existent at worst (something Tony Kushner will explore through the character of Roy Cohn in Angels in America). The gay threat to boundaries comes from their inherent refusal of 
boundaries on a basic level; as Simon Watney argues, the identity "gay" posits "a political and legal unity of interests between subjects variously categorized as perverse/sick/mad/queer/contagious and so on" (18-19). Homosexuality, through the ability of those who engage in its sex acts to pass essentially unnoticed amidst a predominantly heterosexual populace, rejects boundaries wholesale, and threatens a perceived, though actually imaginary, hetero-only way of life.

Yet morality and such similar ethical concerns only went so far when it came to the ways in which the hegemony constructed and confronted the homosexual threat. Lee Edelman, in his consideration of the 1964 Life magazine article "Homosexuality in America," argues that the Life article "unfolds its reading of homosexuality as a threat not merely to the moral spiritual wellbeing of those who are gay, but more importantly, to the happiness of 'innocent' heterosexual men and women as well" (Homographesis 152-153). The mere presence of homosexuals is enough to challenge the potential happiness of the heterosexual majority — a pursuit inscribed as an American ideal. Such challenges are compounded, Edelman argues, because "the ability of most homosexuals to 'pass' produces an extraordinary degree of interpretative anxiety for heterosexuals - and especially for heterosexual men" (152). The Life article, then, operates differently though towards similar ends as the Miller and Clevenger statements on the Congressional Record. Where the Congressmen can effect political and governmental action through their attempts to uncover homosexual identities, the Life article operates on a cultural but also, through its multi-page photographic spread, a visible, visual level that "revealed" the secret world of homosexuality operating in and around the known, heterosexual-based one. That the Life article spent so much ink situating the challenges of homosexuality in the public restroom comes as little to no surprise. The men's room had long been a site of conflict and contention 
over the fear of homosexual encroachment. ${ }^{7}$ Homosexuality's threat towards the homosocial ${ }^{8}$ was never more pronounced than in the men's room, and homosexuality, laden with its metaphors of femininity and physical/moral weakness destabilizes the actions within, and indeed the very function of, the men's room. Writes Edelman, “the American bathroom is 1964 constituted an unacknowledged ideological battleground in the endless - because endlessly anxious - campaign to shore up 'masculinity' by policing the borders at which sexual difference is definitionally produced" (159). The men's room, like the very halls of Congress, offered no protection from homosexuality, and every attempt to control and construct, through physical walls as well as legal means, boundaries and barriers only served as reminders of the porous and uncontainable nature of sexuality.

The ways in which $20^{\text {th }}$ century America used the language of crime and disease when discussing homosexuality was neither unique nor new. Prior to the invention of the homosexual as a subject in the $19^{\text {th }}$ century, ${ }^{9}$ it was the sex acts themselves, collectively better known under the banner of "sodomy" that were deemed unnatural and sinful. Ed Cohen explains in Talk on the Wilde Side how, over the course of the past five centuries, public controls over homosexual sex acts shifted from the church to the state. "The criminalization of sodomy [by the English parliament in 1533] would seem to have effectively transferred the power to define and punish

\footnotetext{
${ }^{7}$ This seems to hold true whether the location of the men's room is in a public venue like a park, mall, or pool, or in more structured environment such as a locker room for a sports team or on a military base or vessel.

${ }^{8}$ Consider here Eve Kosofsky Sedgwick's use of the term in Between Men, where she defines it as the "social bonds between persons of the same sex" and argues, "it is applied to such activities as 'male bonding,' which may, as in our society, be characterized by intense homophobia, fear and hatred of homosexuality" (1).

${ }^{9}$ As outlined in Michel Foucault's History of Sexuality, Vol. 1: An Introduction (1978).
} 
'unnatural' sexual practices to the state and conversely to have made the state ... the sole source for establishing the range of acceptable, legitimate, or 'true' relationships," Cohen writes (104). And so the state became the legal enforcer of the moral code established by the church. For over 500 years, sodomy and homosexuality have continually been met with the paired insults of being immoral and illegal, that is to say both unnatural and unlawful.

Just as homosexuality had long been considered a public health issue wrapped up with religious concerns of sin, so too had other health concerns long been bound together with connotations of moral improprieties. As Peter Lewis Allen writes, "there was a long tradition in the West of seeing disease as God's punishment for sin—especially for sexual sins" (xv). And in America and Europe, the emergence of the HIV/AIDS epidemic within the homosexual community seemed to confirm all of the homophobic rhetoric about homosexuals, including the misperceptions that the existence of homosexuals was itself a sin against God and a threat to the health and welfare of the mainstream, heteronormative society. While on the surface such beliefs seemed contrary to a society so medically advanced, the national discourse still framed the AIDS discourse around matters of guilt, shame, and sin. "Despite America's apparent modernity," Allen argues, "many people in this country—including many of those in power-were convinced that the healthy were saved and the sick were damned" (xv). These ideas even reoccur, sometimes without challenge, in the literature of AIDS, including in the novels and plays I will discuss in the first two chapters. The swift rise of the AIDS epidemic as a public/social medical crisis, coming just as gay civil rights movements were taking off in new directions following the death of Harvey Milk, effectively gave new ammunition to anti-gay religious and political figures. As Andriote argues, "Now those already inclined to hate gay people cloaked the daggers of their bigotry in the guise of concern for public health" (65). And the more the general public 
learned about AIDS, the worse it all became: "Once the public became aware that AIDS could be transmitted through the blood supply, fear, panic, and a pent-up hatred for homosexuals was unleashed in a sudden and virulent storm of media coverage" (65). Tainted blood became the goto narrative, particularly when discussing heterosexuals infected with HIV (consider teenage hemophiliac Ryan White, who literally became a poster-child for transfusion infection in the mid-80s, or Kimberly Bergalis, who became infected when her HIV+ dentist removed two of her molars in $1987^{10}$ ). The early narrative surrounding AIDS was crafted to reinforce the hegemonic ideals of guilt and innocence, and each new case could either reinforce the sinful, diseased state of the homosexual or the physical threat (and the lack of any true protection from that) of homosexuality.

Fears and anxieties over a corrupt and contaminated blood supply remained even after the medical community isolated HIV and created procedures for testing for the presence of the virus in blood. The media was always on the look out for the next "innocent" heterosexual infected because of someone else. Too often, these cases were positioned in the language of innocence and sin, in an effort to ward off the stigma that everyone infected was damned; there were special cases where innocence was corrupted and these served only to reinforce the powerful forces of bigotry that represented all gays as both sinful and public health threats. Susan Sontag recognized the dual structure of such arguments, especially when deployed in the public sphere as warnings for a culture threatened by the homosexual outsider in its midst. "That it is a punishment for deviant behavior and that it threatens the innocent- these two notions about

\footnotetext{
10 The list of "innocents" infected with HIV/AIDS throughout the 80s and 90s goes on seemingly without end as each new case was paraded through the media. The cultural power of such infection stories pervades even still - in 2013, a Tulsa, Oklahoma dentist was accused of exposing over 7,000 of his patients to HIV and Hepatitis (Lupkin).
} 
AIDS are hardly in contradiction," Sontag argues. "Such is the extraordinary potency and efficacy of the plague metaphor: it allows a disease to be regarded both as something incurred by vulnerable 'others' and as (potentially) everyone's disease" (64). Sex and sexuality, long burdened with the stigma of guilt and perversion, could be blamed for the destruction of innocent lives. ${ }^{11}$ Moreover, by blaming the gay community for AIDS movement through the blood supply, the guilt attached to general sex acts could be shifted almost entirely to gay sex acts and heterosexual sex could be rewritten in the language of innocence.

In the early 1990s, Mary Fisher became the public face of heterosexual AIDS when she revealed that her ex-husband had infected her with HIV when they were married. Fisher, a white, conservative Republican from the South came from a politically powerful family with close ties to several presidents, including President and Mrs. Ford (whom she called "Aunt Betty").

Fisher's case is complicated, mostly because while she was being used by the establishment to reinforce the threat of AIDS to a healthy mainstream society, she also used her position to advocate for better treatments and further funding for those infected with HIV. In 1992, she was invited to speak at the Republican National Convention, where, instead of delivering a rousing political speech, she gave an impassioned plea for compassion, and a separation of the idea that somehow AIDS was political in nature: "the AIDS virus is not a political creature... Though I am female, and contracted this disease in marriage, and enjoy the warm support of my family, I am one with the lonely gay man" (Fisher 240). Of course, despite Fisher's best intentions, the

${ }^{11}$ Gay men too perpetuated the discourse of innocence and guilt when it came to AIDS infections. In a 1994 column for the New York Times Magazine, Stephen Beachy, describing both himself and Generation $\mathrm{X}$ at large, wrote "At this point, let's face it, we're the least innocent of 'victims' -- we have no excuse, the barrage of safe sex information, the free condoms, blah blah blah. ..." (52). 
essentialized image of a gay man she conjures up is one that sees only loneliness and despair, without the family support she receives, but more importantly, ignorant of the reality of the efforts of the gay community over the previous decade in building a community of support and care. Regardless of Fisher's best intentions, her presence and voice at the Republican National Convention allowed her to be used and read as a victim of the those dangerous outsiders. Gay men, after all, were not invited to speak at the convention; rather, they were kept apart and outside, as it were, and Fisher's physical presence less a stand-in for gay voices and representation and more a reminder of the threat of dangerous and perverse outsiders. Fisher's infected body reinforced the validity of public anxiety over porous social boundaries- the infected physical body a microcosm of the contaminated national body where now gays represented AIDS and death, rather than communism.

The AIDS epidemic then only served to strengthen the (imaginary and heteronormative) notion that homosexuality threatened the way-of-life of everyone; those who did not practice such deviancy were now just as susceptible to its woes as those who did. Along with the virus came fear and worry that the gay community, already operating as cultural outsiders, would need to be forcefully quarantined as medical outsiders. Those who once called for quarantines on the basis that members of the gay community were sexual deviants and perverts reworked their arguments and shifted such calls for isolation into positions that required quarantines as a matter of public health, not public decency. Simon Watney recounts hearing a doctor and researcher on $\mathrm{BBC}$ radio "calling for the 'removal' of 'AIDS victims' to quarantine centres because, as he put it, "hundreds of people are going to die"” (54). ${ }^{12}$ In 1983, the American Family Association

\footnotetext{
${ }^{12}$ Watney is referring to Dr. Adrian Rogers, speaking on BBC News, Radio Four, 11 Sept. 1986. Watney notes that the doctor was not referring to homosexuals when he says "people," since he
} 
(AFA) fundraised off of a direct-mail letter calling for quarantine: "Since AIDS is transmitted primarily by perverse homosexuals, your name on my national petition to quarantine all homosexual establishments is crucial to your family's health and security" (qtd. in Patton Sex \& Germs 85). The AFA mirrored the predominant historical discourse surrounding homosexuality, merging concerns of moral perversion with both personal safety and security from dangerous deviants. Leo Bersani argued that AIDS stripped away much of the power and clout the gay community had slowly been acquiring post-Stonewall, yet even then this was not enough: "Frequently on the side of power, but powerless; frequently affluent, but politically destitute; frequently articulate, but with nothing but a moral argument—not even recognized as a moral argument - to keep themselves in the protected white enclaves and out of the quarantine camps" (205, emphasis his). Moreover, having been freed of perceptions of homophobia, public declarations about the dangers of homosexuality to the mainstream culture that called for quarantines could be centered on the epidemic's public health crisis. Gays had been perceived as threats to the children of America for so long, and the AIDS epidemic served as a silver platter upon which they could be offered to the gods of family and safety. This desire to craft public perception of the gay community as 'strangers in our midst' also extended the argument then to how many funds should be allocated towards the study and cure of AIDS. After all, if it really just affected deviants then research on the epidemic became less about a cure than about disease (and immorality) management. As Bersani argued, "having the information necessary to lock up

is unconcerned with those who fail to engage in "moral behavior" (54-55). Watney also quotes Paul Cameron, "an American consultant to Republican representative William Dannemeyer" who argued that "had a quarantine been imposed in ' 81 we probably would be looking at a very small expenditure," though of what, Watney is unsure, as America had spent little to nothing on public health (55). 
homosexuals in quarantine camps may be a higher priority in the family-oriented Reagan Administration than saving the heterosexual members of American families from AIDS" (201). Within this heterosexual ideology is the belief (itself an imaginary relation) that there is some form of radical difference between hetero- and homosexuals; as this difference is revealed to be instead an illusion, it produces an anxiety within the mainstream culture that pushes back with homophobic and, when it comes to AIDS research and education, life-threatening public policies. Instead, as we saw in the Cosmo article and as I will analyze further in the coming chapters, sexual identities (and the sex acts themselves) are complicated and messy precisely because we so closely link the acts of sexuality with identity politics even if such definitions do not actually line up or form absolute pairings. Heterosexual sexuality is just as unstable and porous as its homosexual counterpart; rather than being constrained to only one sexual identity, sex acts, such as anal sex, can be (and is being) engaged in by both hetero- and homosexuals regardless of whether or not it is consider rough or "brutal" sex. Sexual instability, in both act and desire, is then a shared relationship, and a real one that threatens the imaginary discourse of a homophobic heteronormative ideology.

\section{SEXUAL ACTIVITY AS IDENTITY}

Within the gay community there existed a separate, though connected, ideology concerning gay identity that also rested on the imaginary rather than the real. In the years following the Stonewall Riots of 1969 up to the emergence of AIDS in the early 1980s, gay men had a very specific imaginary relationship to themselves that embraced sexual liberty as personal identity. If the mainstream, heteronormative world insisted on painting homosexuality as a lifestyle of deviancy and perversion set outside and apart, then the gay community would 
respond by embracing that very status. Allen notes, "One of [the gay and lesbian movement's] earliest and most basic objectives, especially for gay men, was sexual freedom: the right to have sexual lives that were untrammeled by the conventions and limitations of society's norms" (125). Sexual freedom, more than just a cultural touchstone, became a call-to-arms for the gay community as it struggled for visibility; it also challenged calls for acceptance and equality. True liberation meant acceptance of all facets of gay life and being, including (and especially) gay male sex acts. And as AIDS emerged, the epidemic threatened this foundation of gay culture and community - in their cultural imaginary, if the gay community lost their ability to be sexually liberal, they would lose their very identity as well as the potential for true social and civil justice and equality. But whether sex acts are conducted in public or private spheres, sexual identity is the actual basis for the gay community, even more so than sexual desire or sex acts which may preclude the self-identifying "membership" nature of the overall gay community. And while the sexual revolution of the 1960 s and ' 70 s felt like liberation, on a juridical level the gay community was no freer than it had been in the 1940 s or ' 50 s. Sex acts were that thing to which the community could (and would) present as a victory when there were so few legal or cultural victories to actually hang their hats on.

The gay community, as its members would claim repeatedly throughout the 1970s, had earned, through the Stonewall protests, their right to be free from the oppressive demands of heteronormativity, monogamy, and sexual shaming that had previously governed American culture and kept homosexuals firmly rooted in the closet for so long. Conceptual artist Jenny Holzer seemed to speak directly to the political position of gay civil rights defined itself through demands for sexual liberation. In one of the pieces in her Survival series from the mid 1980s, Holzer asked “WHAT URGE WILL SAVE US NOW THAT SEX WON'T?” The appearance 
of AIDS threatened all that sex-as-freedom; sex in the 1980s was no longer seen as a liberating act, even within the gay community, but rather as a life-ending one. Voices within the queer community that had been shouted down or drowned out during the 70s push for sex-as-identity rose up again and challenged the community's over-reliance on sex and sexuality as a means for establishing communal bonds and social equality. But their challenges were no less ideological than those they pushed back against. The argument that gay sexual acts were not the basis of the gay community seems to ignore the actual real conditions on which the gay community is founded, a coming together of men who share in sex acts with other men. That some men who engage in same-sex acts choose to identify as gay while others do not does not inherently negate the sexual basis on which the community is built. And, as we will see in works like Angels in America, The Normal Heart, and The Beauty of Men (which will be analyzed in the first two chapters), this argument spilled over into, and was furthered by, the gay literature of the time. Bathhouses across the country became the battleground for this ideological debate over the identity of the gay community. Closing the bathhouses, sites historically a focal point for underground male (homo)sexual relations, became a divisive point for a struggling community in the time of plague. On one side was the voice of the establishment - the medical and political communities both outside of and a part of the gay community - that saw the bathhouses as spreaders of contagion and sites of contamination. ${ }^{13}$ Yet many in the gay community saw closures as poorly disguised attempts to regulate gay male sexuality, reining in their lifestyle of sexual extravagance, plurality, and freedom that they saw as the foundation for the awakening gay cultural identity. Andriote recounts the pro-sexuality ideology as one in which the gay

\footnotetext{
${ }^{13}$ Priscilla Alexander saw such a point-of-view as an approach that "scapegoats places as surrogates for the actors playing in the context of a dreaded disease" (222, emphasis hers).
} 
community "dug in their heels" in opposition to all calls for the reining in of sex acts. Andriote's language, while ostensibly historical in form, argues for an anti-promiscuity ideology, painting pro-sex voices as unreasonable and attacking; "Community leaders were verbally flayed for daring to suggest that perhaps gay liberation and sexual license had been conflated once too often. Newly formed AIDS organizations hesitated to tell gay men 'how' to have sex in ways that might save their lives lest they, too, be dismissed as homophobic and puritanical" (48). Bérubé's passionate public defense of the bathhouse ${ }^{14}$ took a historical approach to the struggles surrounding attempts to close bathhouses around the country, and defended them as institutions for sexual and political purposes; "No longer clandestine, this new generation of bathhouses [that emerged post-Stonewall] established themselves as a major gay institution that could both shape and respond to the rapid social, sexual, and political changes that were taking place" ("History" 200). Attempts to close the bathhouses, then, were also attempts to stifle and limit the growing political power of the gay community. For Bérubé, the culture that had once made all gay men criminals wanted to return them to such a status; "Because all sex acts between men were considered public and illegal, gay men were forced to become sexual outlaws" (189, emphasis his). Closing the baths would force gay men out into the streets to find other, more public, less safe spaces for homosexual intercourse (216), an argument shared by those outside the gay community as well.

As more and more politicians and government officials called for the bathhouses' closures, the issue remained politically fraught and drowning in the language of morality disguised as public health. In late 1985, an editorial by The New York Times, "Morality, AIDS

\footnotetext{
${ }^{14}$ Submitted in 1984 to the California Superior Court and again in 1985 to the New York State Supreme Court
} 
and the Bathhouses," challenged the intentions of those attempting to close the few remaining gay bathhouses in the city. "If they're inspired by public morals, this may seem like an opportune moment to drive the bathhouses out of business," the paper observed. "But if public health is the aim, that may not be as good an idea as it sounds." The editorial argued that bathhouses were sites for not only sex acts, but also sex education. But even as it challenged closures under the mask of morality, the editorial still perpetuated an ideological point-of-view that could be construed as anti-gay-sex. "AIDS is spread by sexual practices, like anal intercourse, which let the AIDS virus into the bloodstream," the Times reasoned in its defense. "The disease is prevented by avoiding those practices, and the bathhouses are supposed to carry posters and literature advising patrons on safe sex." The paper, in its pro-bathhouse rallying, only really read them as sexual institutions, ignoring or downplaying their historic communal functions. So when the Times writes that "The bathhouses seem to respond to an important need for some homosexuals," it really means homosexuals' 'sexual needs' as it follows that declaration with the warning, "Though closing them might win some votes, that need will remain, to be satisfied in ways and places that are less safe." Even the supporters of the gay community could only read such a grouping as one of a sexual nature. Additionally, editorials such as this promoted some sort of ideological difference between homo- and hetero- sex acts and activities that disallows for a "safe" homosexual community apart from the bathhouses, or indeed, a gay community apart from sex acts at all.

Public health officials calling for bathhouse closures, and the gay men who promoted such actions, found themselves treated by the gay community at large as oppositional forces, no better than the conservatives and religious fundamentalists who called for quarantines and/or incarceration. When San Francisco public health director Merv Silverman ordered the last 
remaining bathhouses in the city closed in late 1984, he defended his actions, saying, "Make no mistake about it: These fourteen establishments are not fostering gay liberation. They are fostering disease and death" (qtd. in Shilts 489). Silverman's order challenged, and rejected, the imaginary relation gay men had created between themselves. Nor was he alone in his concerns; noted gay activists Bill Kraus, Cleve Jones, and Ron Huberman penned a letter to the Bay Area Reporter in early 1983 decrying unsafe sex, and specifically "unsafe sex with a large number of partners. For this reason, unsafe sex at bathhouses and sex clubs is particularly dangerous..." (qtd. in Shilts 259). Their open letter argues against reading gay male community as a product of sexuality and sex acts. Andriote recognizes the ideological forces at work behind such animosity toward closing the bathhouses; "Would the community have resisted less if gay men had been more confident that their basic human rights were not at stake in the debate over sex and bathhouses?" he asks (82). Andrew Sullivan is less forgiving. Looking back more than a decade later at the ideological choices of the gay community in the 1980s, Sullivan condemned the ideology at work behind such imaginary relationships: "even in the teeth of a viral catastrophe, saving lives was less important than saving a culture of 'promiscuity as a collective way of life,' when, of course, it was little more than a collective way of death" (52).

Sullivan's lack of understanding reveals his own ideological constructions, particularly in consideration of his own sordid entanglements surrounding sexual freedom and seroconversion, which is the time in which a person is already infected but the virus is not yet detectable. Sullivan's public morality was put to the test when light of his private profiles for bareback sex came into view. Sullivan had, so the gay press reported, taken out ads that "solicited bareback sex, preferably (although he did not say only) with other HIV-positive men" (Kim). And while many in the gay community, including Michelangelo Signorile who published an article "outing" 
Sullivan's hypocrisy, were quick to excoriate Sullivan, Richard Kim cautioned against such moralistic pronouncements: "In finding him a sinner, do we end up concurring with Sullivan's original understanding of sin-if only to turn the tables on him? In doing so, we don't challenge the moralizing, normalizing values that Sullivan espouses. We just relocate ourselves, temporarily, on the other end of the finger." Moreover, Sullivan's own struggles with sexual desire, morality, and public health, remind us of one of the gay community's very real relations to human sexuality: sexual desire cannot always be controlled by rational thought. Sullivan's hyper-conservative moralistic ideology can only function if, while he writes such proclamations, he can displace his own sexual desires and actions.

Not that an anti-promiscuity ideology was without (then or now) its intellectual supporters. When it came to the controversy over closing the bathhouses, Priscilla Alexander was having none of it. For Alexander, when gay activists want to shut down the baths or "tell gay men to be 'responsible,' it represents a public denial of the sexual self, internalized as dirty, polluted, and diseased to begin with, and a concomitant desire to identify with and be accepted by the world of the "normal"” (235). Michael Bronski, in his historical examination of gay culture in America, reads the closing of bathhouses nationwide as homophobic acts intent on persecuting gays, not helping them; "It is clear, from selective enforcement and the use of coded language, that these efforts were actually attempts to regulate sexuality rather than promote public health" (227). Bronski is drawing this conclusion from a 1996 Marc Elovitz and P.J. Edwards' essay that criticized blanket restrictions by the New York City Department of Health on both protected and unprotected anal sex in commercial establishments as "more a reaction to heteronormative anxieties rather than a legitimate measure to protect public health" (296). A flaw in Elovitz and Edwards' specific argument here (and by extension, Bronski's) is that they 
are taking into account knowledge of studies into "means of transmission" that, while may be considered more reliable in 1995 when they are writing, were not as well understood or accepted when the city moved to close the baths in 1986 (296). Elovitz and Edwards, like Bronski, Alexander, Bérubé, et al., bought into the ideological fantasy that defined gay identity as one overly reliant of promiscuity and public sexuality rather than the competing ideological construct that presented gay identity as one of both individuality and community apart from, or at least not restricted to, sexuality and sex acts. These competing ideologies used the AIDS epidemic as the battlefield for determining what constitutes gay and gay sex acts.

\section{EVOLVING IDEOLOGIES}

The AIDS epidemic became the stage for the gay community's discourse on what constitutes the gay identity and what it means to actually have / be a part of a gay community. Many within the gay community who were pro-sex, or more specifically pro-sexual liberation, argued for an ideology that read gay sex acts as the functioning basis of gay identity, and in turn of the gay community with whom one was having lots of gay sex. Policing of gay sex acts, both literally and figuratively, by the hegemony had long prevented the maintaining of a public space for gay men. The conservative ideology that opposed promiscuity instead argued to differentiate between sexual desire and gay sex acts - to them, it is the desire that makes one gay, not whether or not one has gay sex. Both ideological positions stem from a desire to understand, and through understanding defining, what constructs a gay identity and the gay community at large. But each position must also elide problematic challenges that arise through ideological challenges. Sexual liberation, taken at face value, is not inherently wrong, immoral, or unwise; but the presence of the AIDS epidemic means that enacting identity through sexuality takes on clear and specific 
medical/health dangers, risks that for many years were fatal in nature, even if the community does not want to admit to them. With the ideological opposition, there is the stretch in logic that insists one can base an identity on sexuality or the desire to have specific sex acts without actually having any sexual activity. Neither side is wrong, per se, but neither is either ideology right or correct; both rely on embracing certain imaginary relations in order to develop an understanding of what it means to be gay and a part of the gay community.

Mainstream cultural ideology concerning homosexuality and the gay community has undergone several significant changes in the decades since the AIDS epidemic began. One cultural shift has been the construction of the gay best friend. Films like My Best Friend's Wedding (1997) and television shows like Will \& Grace (1998-2006) and Queer Eye for the Straight Guy (2003-2007) presented gay characters as helpful and essentially harmless to the heterosexual social and cultural hegemony. And while these cultural texts are often criticized for more often than not representing homosexuals as effete and feminine, they still showed a significant change from the ideology of the life-threatening and dangerous homosexual of the 1980s. Yet beyond the gendered and over-sexualized stereotypes over-represented within these mainstream texts, they promoted a different imaginary relationship between hetero- and homosexuals. Instead of demonizing gays, these works went out of their way to promote homosexuals as overly refined bastions of culture and taste, whose essential function was to bestow their abilities on the unwashed heterosexual masses. As positive cultural visibility increased, so did a sociological understanding of the gay community that still presented it as different from but not dangerous toward its heterosexual counterpart.

Alongside this cultural perception, another ideological construct of homosexuality gained traction: the homosexual as medical abnormality and therefore curable. As Andrew Sullivan 
argued, "an old but trusty theory was resurrected" called "“reparative' psychoanalytic therapy" that once again connected the homosexual to sexual deviancy, a pathology of a medical, rather than moral, nature (90). Moreover, cultural and religious conservatives connected these attempts to the ongoing medical breakthroughs in the treatment of AIDS; "As a cure for HIV approached, the right did what it could to advance the notion of a cure for homosexuality itself" (90). In this sense, the same ideology surrounding homosexuals and AIDS mutated and became subtler in its presentation and promotion. For example, though its origins dated back to the 1970s, the ex-gay movement, a religious based "cure" for homosexuality and homosexual desire, gained considerable cultural momentum in the 1990s and early 2000s. Only in the past couple of years, and then only for cases involving minors, have states begun promoting and passing laws banning ex-gay reparative therapy as potentially harmful. These two cultural perceptions (gays as helpful companions and gays as medical abnormalities), though both essentially imaginary constructs, conflicted with one another, furthering the cultural divide between liberals and conservatives. Ideologies shifted and changed within the gay community as well. Sullivan observed this shift as a resurgence of past arguments, albeit now taking place within the shadow of the AIDS epidemic. "An ancient squabble broke out," he argues, "between those who feared that continued promiscuity could put yet another generation of gay men in mortal danger and those who defended and even celebrated that promiscuity as somehow definitive of what it was to be gay" (89). Additionally, with the advent of the HIV drug cocktail (a combination of multiple antiretroviral drugs), the gay community moved from managing day-to-day health related issues to returning their fight towards social and political equality. The community pushed for same-sex marriage, open service in the military, medical and healthcare benefits, and nondiscrimination policies in housing and employment. William N. Eskridge, Jr. used the push towards marriage 
equality as a push-back against "promiscuity," challenging the gay community to embrace "the civilizing effect" of marriage: "It should not have required the AIDS epidemic to alert us to the problem of sexual promiscuity" (9-10). Eskridge's ideological position was not without its detractors. Bronski argues that it is telling how "when the AIDS epidemic is mentioned in relation to same-sex marriage, particularly from within the lesbian and gay community, it is always to reinforce the myth that the promiscuity that allegedly led to the epidemic would never have happened if gay men had been allowed to marry" (241). While Bronski's own attempts to bust the ideological myths promoted by Eskridge appear valid, they are held in check by the underlying assumptions of Bronksi's own positions that still support an ideological illusion that promotes promiscuity as identity and fundamentally oppositional to the heteronormative constructs of monogamy and marriage.

Another significant ideological move a portion of the gay community made was a return to the reading of homosexuality as oppositional to heteronormative society. Unlike heteroculture that sees this opposition as a bad thing — the end of civilization, if you will—queer theorists, given voice in Lee Edelman's No Future (2004) for example, read oppositional queer representations as positive reclamations of homosexuality's position outside of the mainstream. While this point-of-view more often than not took the form of being pro-sexual liberation, it also revealed a distinct subset of the gay community that rejected the "safer sex" push towards condoms as also heteronormative. Called "barebacking" after the riding of a horse without a saddle, condom-less sex was a dangerous alternative in a community still dealing with AIDS. In 1997, Stephen Gendin contributed an article for $P O Z$ magazine, entitled "My Turn: Riding 
Bareback," that glorified unprotected anal sex with another HIV + man. ${ }^{15}$ The gay community, or at least that portion of it that read $P O Z$, reacted quite differently than their early 80 s counterparts: “After [Gendin's] article appeared, POZ was flooded with letters, the majority of which condemned Gendin for glamorizing a behavior that would lead men to court death" (Shernoff 14). Gone it seemed was the general populace that embraced the rhetoric of open and liberal sexual activity as a liberating culture, and in its wake came one of rules and regulations, ostensibly designed to keep one safe. But Gendin's article only publicized an already operating division of the gay community that not only embraced sexual liberation but also rejected safer sex options that appeared as heteronormative constraints on sexual liberation, regardless of whether or not such actions and rejections resulted in infection. As such, Tim Dean's analysis of the barebacking subculture argues for a cultural choice founded in the aftermath of AIDS: "Gay men have discovered that, on the basis of viral transmission, they can form relations and

${ }^{15}$ Gendin's language is itself an ideological marker, burdening sex with Puritanical concerns of guilt (and, rather than innocence, the absence of guilt). Wrote Gendin, "I'd had unsafe sex before, but never intentionally. Those experiences were guilt-ridden because I worried-both during the sex and afterward - about exposing my partner to HIV. This was different. Knowing the guy was positive made it empowering, not guilt-inspiring." Gendin's own examples were complicated when, two years later in November 1999, he and his HIV- boyfriend Kyle "Hush" McDowell cowrote in "Both Sides Now" for $P O Z$ about how barebacking resulted in McDowell becoming positive: "Hush and I fought over whose fault it was, and I found myself in a deep depression, my first ever" wrote Gendin. "I felt incredibly guilty: I'd cut in half the life of the person I loved most in the world." For his part, McDowell blamed his codependent feelings for Gendin as well as the de-sexualizing nature of safe-sex education: "I always used condoms with anal sex, and rarely had oral sex without one. This extra vigilance made me different from every gay man I knew; it also made sexual negotiation an embarrassing chore. In fact, the entire safer-sex code made me feel desexualized." 
networks understood in terms of kinship — networks that represent an alternative to, even as they often resemble, normative heterosexual kinship" (Unlimited $\mathrm{x}$ ). Put more bluntly, sharing the HIV virus through unprotected sex can create a different kind of gay community-a subculture of the infected, or of those wishing to be infected (colloquially known as "bug-chasers") - that rejects a heteronormative desire of futurity. Dean's text goes out of its way to emphasize the sharing of the virus as a foundational construct of the bareback community so that HIV- gay men who engage in condom-less sex with each other do not appear to fit into the bareback community as he describes it. But there are plenty within the gay community who do not share this limitation, including major gay porn websites like Sean Cody and Corbin Fisher who frequently release videos featuring two or more HIV- performers under the label "bareback" and caution against unprotected sex in practice outside of the fantasy of pornography.

While the intellectual debate over sexual freedom as a foundation of identity continued, the white gay male community as a whole seemed to move on towards calls for equality. Marriage equality dominated the political and social narrative as major voting referendums (including California's now infamous ballot battle over Proposition 8 halting same-sex marriages statewide). And throughout the 2000s, with infection rates dropping and infected men and women in America generally living longer (so long as they were taking their meds), AIDS fell out of favor with the general narrative for social and political equality. The ideology of AIDS, for the white gay male community then, became similar to the mainstream culture's point-ofview: AIDS now belonged to those others, over there, and connecting it to the lived historical and current experience of gay men did more harm than good. 


\section{CHAPTER SUMMARIES}

The first two chapters focus on the theatrical literature of AIDS - those texts that emerged on stage during the initial onslaught of the epidemic and drove discourse and desire throughout the 1980s and '90s. These chapters look more closely at the ideology of AIDS, how it was presented by the gay community, and perhaps most importantly, how it interpellated gay individuals as ideological subjects. Chapter one focuses on The Normal Heart by Larry Kramer (first performed in 1985) and chapter two addresses Angels in America by Tony Kushner (first performed in two parts in 1991 and 1992). Both of these plays (re)present the conflicting, though not mutually-exclusive, ideologies of AIDS, as well as display those elements of the queer connection with AIDS (for example gay subjectivity and the development of a queer-oriented community) that would, in $21^{\text {st }}$ century texts, be found as traces. Kramer and Kushner presented to the gay community their attempts to give voice to the ideological fantasies that surround and subsume the AIDS epidemic. Moreover, it is not about what identities or historical moments are included or excluded in the plays' representations of the early days of the epidemic. Rather, the plays are being considered in light of how they present a specific ideological fantasy about AIDS and what things must be excluded or overlooked in order for the fantasies to properly function.

The third chapter continues the examination of primary, AIDS-centered texts begun in the first two chapters. Here Andrew Holleran's novel The Beauty of Men (1996) and collection of essays/memoirs Chronicle of a Plague, Revisited (2008) are analyzed in regards to how they capture and express the phenomenology of AIDS. Chronicle, expanded from when it was originally published as Ground Zero (1988), offers insight into the changing ways AIDS phenomenology was presented with autobiographical texts written by gay authors. Both Holleran's novel and collection of essays are less concerned with the political, historical, and 
ideological structures that brought about the AIDS epidemic, and more concerned with how gay men lived within the disease — how they formed social relationships, community structures, physical attachments to both people and places, and how their sensory experiences of the epidemic created their individual and collective subjectivities. The shared experience of AIDS becomes the foundation for the (re)emerging/restructuring gay subculture; in a phenomenological sense, the community gains an awareness/consciousness of who it is by examining more carefully what it is not (or perhaps more precisely, what it no longer is).

The fourth chapter focuses on the traces of AIDS in $21^{\text {st }}$ century young-adult gay literature, following the threads of the ideology and phenomenology of AIDS begun in the prior chapters. Young-adult works share their own specific sets of complications, precisely because their focus is under-age readers who must often navigate parental controls and/or institutional permission/censorship in order to read works which speak directly toward their awakening desires. While there have been several works of young-adult fiction that address the topic of AIDS, novels like Boy Meets Boy by David Levithan (2003) and Hero by Perry Moore (2007) do not. More often, they paint rosy portraitures of gay life beyond the coming out stage, to the neglect of a complex sexuality that continuously (re)defines a queer individual's place within the greater social, political, and cultural structure. Yet the presence — the memory-of AIDS looms over these texts, and the novels still contain the trace of what AIDS was/did to the gay community that came before them. This trace is found in the way in which identities collapse within the narratives, as well as the novels' use of gay pride and gay shame, and the manners in which the characters process and cope with these emotions. These texts ask the same larger questions that AIDS-based texts do: if we create ourselves, our identities, based on other people, what happens when those people are no longer around? These conflicts of 
understanding/knowing each other, gay pride, and gay shame create similar conditions for and challenges to identity and subjectivity as those experienced by gay men facing the AIDS epidemic head-on. Separately, by creating worlds without AIDS, these novels (especially Boy Meets Boy) attempt to create a new version of a "gay fantasia," one that counters the stark realities and oppressive ideological structures of the gay fantasia presented by Kushner in Angels in America.

As the dissertation concludes, it pauses to look at future possibilities for analysis where this argument could be extended (or even challenged), for while this work looks primarily at texts about gay men, future work could examine the relationships of women, lesbians in particular, as well as the black community (both in America and abroad) to the AIDS epidemic and how the ideology and phenomenology of AIDS differs for them. Future analysis could also include a broader look at what the trace of AIDS was for the rest of the queer community, including its resurfacing in texts on transgender equality that often invoke similar metaphors of sickness, health, and public safety. 


\section{Chapter One}

"A Social Death": The Ideology of the AIDS Epidemic in Larry Kramer's The Normal Heart

Can’t you see how important it is for us to love openly, without hiding and without guilt? (Kramer, Normal 97-98)

In 1983, as the AIDS epidemic garnered greater attention in gay and medical communities, as well as in the mainstream press, ideological struggles over sexual liberation reshaped ideas about who homosexuals were and how they should behave. The idea that sexual freedom was to blame developed out of the limited medical and technological knowledge and resources available at the time. Throughout 1983 and 1984, as the epidemic claimed more lives, medical researchers isolated the retrovirus that caused AIDS, but much remained unclear in regards to transmitting, testing, and, of course, curing AIDS. Although the links to sexual transmission were uncertain, the direct impact of the AIDS epidemic on the gay community allowed many within (and without) to point the blame for the epidemic at the hedonistic and promiscuous lifestyles of those infected and dying. Richard Berkowitz and Michael Callen's 1983 pamphlet How to Have Sex in an Epidemic: One Approach was one of the first organized attempts at creating a public health document that addressed AIDS and gay sex directly and not as something inherently unhealthy, immoral, or a violation of natural law. In the national discourse, the cultural belief that gay sex acts were sinful held sway, even as for some within the gay community, it was displaced onto their own sexual behaviors, in turn promoting the ideological fantasy that sexual freedom was to blame (and somehow monogamy or abstinence 
would save us all). Berkowitz and Callen directly address the conflicting discourse that conflates how gay men have sex with how much they do: "Because the development of AIDS in gay men is obviously somehow connected with the amount and kind of sex we have," they write, "a lot of advice has focused on 'reducing' the 'number of different partners"' (35). But such a conflation occurs precisely because of the limited medical knowledge available in the early 1980's for Berkowitz and Callen, and the larger medical and cultural communities; their own introduction structures the discourse as a direct response to those limitations: "If you [...] belong to the group of men for whom such drastic measures [celibacy] would be warranted only if there were firm evidence supporting the existence of a highly contagious new AIDS agent. If you believe, as we do, that the evidence strongly suggests otherwise, read on" (2). As their opinions regarding the medical conditions involved in the transmission of AIDS tie directly in to their ideological stance opposing promiscuity, Berkowitz and Callen come across as confusing —in one instance they argue that how gays have sex is the more important issue for concern ("limiting what sex acts you choose to perform to ones which interrupt disease transmission" [3, emphasis theirs]) - but by the end of the pamphlet they reaffirm the dangers of promiscuity. They challenge the predominant ideological forces of the gay community at work in determining how "sex and 'promiscuity' have become the dogma of gay male liberation" when they ask, "Have we modified the belief that we could dance our way to liberation into the belief that we could somehow fuck our way there?” (39). Furthermore, Berkowitz and Callen separate sex (anonymous or otherwise) from same-sex love when they argue that love and same-sex attraction could be the key to ending the epidemic: "If you love the person you are fucking with—even for one night—you will not want to make them sick. Maybe affection is our best protection" (39, emphasis theirs). Berkowitz and Callen straddle the ideological divide, challenging both the ideal 
of sex as a foundation of gay identity/community and the position that blames sexual freedom in gay male sexuality for the onslaught of the AIDS epidemic.

In the early 1980s, a handful of activists, including Larry Kramer, founded the Gay Men's Health Crisis (GMHC) in New York as both a resource for sharing what little information was known about the growing epidemic as well as helping to meet the physical, emotional, and medical needs of the gay community. Kramer was well known for his screenwriting credits and his novel of late 1970s gay sexual decadence Faggots; his regular columns in the New York Native would put him on the front-line of the AIDS epidemic. When his play The Normal Heart debuted in 1985 , it polarized the gay community through its willingness to blame gay culture as much as the homophobic mainstream hegemony for the continued spread of AIDS. The Normal Heart follows the early struggles of establishing a group quite similar to the GMHC, with its principle character Ned Weeks serving essentially as a stand-in for Kramer and his ideological world-view. The driving drama of the play is the conflict within the gay community itself; even seemingly exterior forces, like the offices of the Mayor of New York, ${ }^{16}$ are represented by gay characters like Hiram Keebler, the mayor's aide.

With The Normal Heart, Kramer presented to the gay community, and the general public at large, his, perhaps unconscious, attempt to give voice to the ideological fantasies that surround and subsume the AIDS epidemic. The play presents fantasies that seem to rely on (chrono)heteronormative constructions of reality, ones that potentially reinforce the gay subject as a cultural outsider and threat. And, although some identities or historical moments are excluded in the play's representations of the early days of the epidemic, the play should be

\footnotetext{
${ }^{16}$ The mayor at the time was Ed Koch, long considered by Kramer and others within the gay community to be a closeted homosexual.
} 
considered more for how it presents a specific ideological fantasy about AIDS and what things must be excluded or overlooked in order for the fantasies to properly function. AIDS (the virus and the epidemic) in the early 1980s was an unknown entity, which, despite the limited medical knowledge of the cultural framework surrounding it, was amoral, neither a mark of a person's moral compass (whether they be good or evil), nor was it punishment for acts (sexual or otherwise). Kramer's play struggles to process the Real of AIDS, the empty space in our reality that the ideologies of the times cannot hold or understand. With The Normal Heart, Kramer challenges the ideological structures that insist gay sex acts should be the foundation for both gay identity and the gay community. Since Kramer preaches the morality of monogamy and abstinence from the public soapbox that is the theater, the play cannot contain, and therefore offers no real space for, an understanding of the virus as amoral.

\section{KRAMER TAKES ON SEXUAL FREEDOM AS IDENTITY}

As the AIDS epidemic progressed, the hegemonic ideologies surrounding it coalesced into (essentially homophobic) responses to the expanding threat of the virus. The literature of AIDS that developed throughout those formative years of the crisis often intervened in those ideological conflicts—at times offering resolutions (symbolic or otherwise) or varying perspectives on the conflicting ideological points-of-view in order to shape and mediate the discourse itself. Some texts were openly instructive, operating almost as agitprop, about their concerns, while others took a more symbolic, subtler approach to steering the public discourse on AIDS. Larry Kramer's The Normal Heart was one of the earliest plays to directly address the AIDS epidemic, and, as is typical of much of Kramer's work, ran headfirst into the political fray with bombast. Kramer's work was often concerned with the public, hetero-oriented, hegemonic 
mainstream's perception of the gay community as promiscuous, sex-obsessed, dangerous perverts, and The Normal Heart focused at great length on the foundations of a community that so aligned its own identity with sexual freedoms, reinforcing the hegemony's homophobic pointof-view while overlooking the amoral nature of the virus.

Larry Kramer never really had a hard time making his feelings known regarding the gay community's embrace of sexual liberation as a form of social protest which developed into a social/cultural identity. Kramer's late-1970s novel Faggots, in many ways similar to Andrew Holleran's novel of and from the same time-period Dancer From the Dance, challenged the future of a gay community that constructed itself through hedonism and sexual liberation, drawing ire from several outspoken writers, critics, and intellectuals within the community. As the AIDS epidemic was worsening, Kramer used the public stage to vocalize his most basic concerns, demanding that the gay community should at the least discuss openly the politics of gay sexual identity in a time of plague. Kramer's insistence that they consider what makes the gay community a community — is there more to it than shared sex acts - drew criticism for its heteronormative ideological values. The Normal Heart is polemic, to be sure, but it was also taken as representative, and in no small way the play successfully forced the gay community to examine its own role (sexual or otherwise) within the epidemic. Although Ned Weeks, the driving protagonist of Kramer's play, stands in for Kramer's point-of-view, overall the play allows space for competing ideas; Bruce Niles and Mickey Marcus, themselves similarly invested in the gay community's future, vocally confront Ned and his protests against promiscuity.

The politics of The Normal Heart challenge the conventional (itself ironically unconventional) view that gay sexuality is a liberating force and that attempts to squelch that 
sexual freedom, for any reason, are merely a shift to heteronormatize a community that rejects the historical oppressions imposed by a homophobic hegemony. While Ned is the primary voice to challenge the dominant ideology of the gay community, he is inspired by Dr. Emma Brookner, who is struggling with managing the care of several men dying from the virus. Emma, in her role as heterosexual outsider, maintains a level of vested interest in the way gay men have sex-her treatment of gay men offers a different perspective than other heterosexual voices in the public discourse, including Ned's brother Felix, for whom gay sex is seen in and of itself as a disease, a danger, and a perversion. Emma's concern is with the potential outcomes of that sex-and with the choices the gay community continues to make in wake of the developing (though certainly still underdeveloped) science surrounding the epidemic. With Emma, Kramer is giving voice to the interested heterosexual participant, more than a casual outside observer, and using that voice to critique the structures of the gay community; "I can't find any gay leaders," Emma complains to Ned (Kramer, Normal 25). And it is through her medical credentials, with Ned undressed on her examining table for most of their conversation, that she argues that gay men are killing themselves through their sex acts. For Ned, halting promiscuous sex is an impossible act, precisely because of sex's cultural significance within the gay community. "Do you realize that you are talking about millions of men who have singled out promiscuity to be their principal political agenda, the one they'd die before abandoning," Ned argues, convinced of the correctness of her statements, just not the possibility of such demands actually being met (26).

For Emma, the cessation of gay sex acts is a straightforward (no pun intended) choice; “doesn't anybody with half a brain stop fucking?" she challenges (27). But for those within the gay community it is a far more complex social, sexual, and mental issue. Even Ned, as he rails against promiscuity, keeps having sex. Andrew Holleran, in his introduction to the first edition of 
The Normal Heart, wrote, "The basis of the whole culture was sex. (As it is of any culture). The smart turned celibate. Others became more orgiastic. But most were Jekyll \& Hyde; rational, health-conscious, aware, we went from the news of some death in all its horrifying detail directly to the baths, and then home to lie awake till dawn wondering if this was the Killer Trick" (25). Holleran is touching on several important matters here. Connecting directly to Ned and Emma's discussion on celibacy as a necessary step, Holleran gives voice to the challenges that the gay community faced when attempting to reconcile their primal sexual drives with their more focused intellectual ideals about sex and safety. But Holleran also challenges the overarching political narrative that the gay community was somehow more obsessed with sex than their heterosexual counterparts; sex is not something that any culture would willingly abandon (after all, the church has spent centuries trying to get its congregants to stop having heterosexual sex outside of specific and rigid confines), and the desire of the gay community to not lose that sexual freedom does not somehow make them deviant, but rather similar to the norm from which they are being called out. Kramer uses Ned to portray the same ideological underpinning that Holleran notes in his introduction: sexual desire itself cannot be controlled by logic or rational thought, a desire that functions regardless of whom the object of such desire might be.

Not that everyone in the gay community was as willing to give credence to Kramer's argument on promiscuity. Writing 20 years after Kramer's play premiered, Dirk Visser is far less understanding than Holleran: "The message that The Normal Heart thus offers its audiences on the disease seems to be that AIDS is a self-inflicted illness, brought on by an unhealthy lifestyle. In other words, Larry Kramer's AIDS discourse is laden with the same moral connotations of guilt and retribution that once surrounded the plague" (190). What Kramer reads as a matter of health and safety, Visser argues is one instead focused on moralistic notions of how one should 
behave. What Visser is picking up on, though not addressing directly, is that kernel of realness that evades symbolism - for Kramer's ideological fantasy to function he has to ignore the ways in which a virus is itself amoral and instead treat it as a symptom of the gay community's collective immorality. Gay sexuality had long been repressed/oppressed and Kramer's call for celibacy was no different in form, or, Visser seems to imply, intent. Visser, specifically writing in 2006 about a current revival of Kramer's play, argued:

Its message of AIDS as a self-inflicted disease on a bunch of sexual radicals is not relevant (if it ever was). Neither is its invocation for gay men to stop having sex. Although AIDS is still an incurable disease, the immediate death threat to American gay men is no longer there. Deathbed scenes, such as the one with which The Normal Heart closes, are not necessary anymore. (191)

Visser's reaction shows how strong the ideological divide within the gay community was (and remains) when it comes to sexual freedom as he essentially equates Kramer's anti-promiscuity credo with a call that AIDS was/is self-inflicted; the merits of the argument notwithstanding, Visser is mistakenly conflating the two ideas. Saying gay men should stop having sex, and moreover that sex may not be the best form around which to build an identity, is not the same as blaming gay men for ever having become HIV positive. That implies a sort of moralistic stance that departs from Kramer's (as evidenced in Emma's complaint based on the medical circumstances). And just as Visser is at odds with Kramer's choices, so too are members of the $21^{\text {st }}$ century gay community at odds with Visser's conclusions. Michael Glitz, writing for The Advocate in 2004, argued that the revival "makes abundantly clear that The Normal Heart is still painfully relevant" (66).

For Kramer, the ideological argument surrounding sexual freedoms is constantly framed 
and then re-framed as a challenge to gay identity and by extension the politics of being gay.

Kramer uses Ned to argue for a resolution to this challenge - there is more to being gay than sex, and someone has to say it. In the play, Ned, much like Kramer did throughout the 80s, writes a blunt and aggressive letter to be mailed out to local gay men that tells them to stop having sex or they, and eventually all gay men, will die.

BRUCE. But we can't tell people how to live their lives! We can't do that. And besides, the entire gay political platform is fucking. We'd get it from all sides.

NED. You make it sound like that's all being gay means.

BRUCE. That's all it does mean! (Kramer, Normal 47)

Ned has shifted into the position once held by Emma, the outsider who does not want to get too involved in the gay politics surrounding AIDS ("She wants to tell them so badly she won't lend her name as recommending it," Mickey complains [46]), thereby reinforcing Ned's position as an outsider within his own community. Yet every time Mickey and Bruce argue for a monolithic approach to gay identity/sexuality (it's the entirety of gay politics so "we'd get it from all sides"), Ned argues for a counter-point and thus fights for a space within the gay community for those with a differing ideological approach. When Ned says that he doesn't like the way he feels about himself when he engages in anonymous sex, Mickey counters, "But not all of us feel that way. And we don't like to hear the word 'promiscuous' used pejoratively" (50). And even though Kramer utilizes characters like Mickey to refute Ned's stances, the text makes little room for an argument that questions how an identity, itself inherently organized around who one has sex with, might be constructed apart from the sex acts themselves.

Too often lost in the discussion about anonymous/promiscuous sex is the distinction between engaging in no sex, engaging in monogamous sex, and engaging in safe sex. The 
Normal Heart attempts to foreground these distinctions, though in places the nuances get lost. When Mickey argues "Sex is liberating" and Ned rebuts, "More sex isn't more liberating" (51), ${ }^{17}$ Mickey and Ned's argument focuses specifically on heteronormative monogamy and not the bigger picture idea that sex is killing them. At times Kramer seems to argue for abstinence (e.g. Emma's "stop fucking"), and in other moments, as in this scene, for monogamy. And because Kramer himself runs over these distinctions non-stop, there is a blending of ideas until it is unclear if he is advocating for abstinence or monogamy. And, as Douglas Crimp calls out, the distinction is significant:

Common sense, in Kramer's view, is that gay men should stop having so much sex, that promiscuity kills. But this common sense is, of course, conventional moral wisdom: it is not safe sex, but monogamy that is the solution. The play's message is therefore not only reactionary, it is lethal, since monogamy per se provides no protection whatsoever against a virus that might already have infected one partner in a relationship. (247)

Within the constraints of Kramer's play (and seemingly within the GMHC organization that Kramer is fictionalizing), no one within the gay community seems to be actually advocating for abstinence as a solution and so we are left with an ideological fight over the middle ground: since gay sex kills, regardless of the amount or kind of gay sex, arguments against promiscuity recklessly imply that there is some modicum of safety in monogamy. Even Emma draws distinctions as she argues with Ned over the community's refusal to stop having sex, "I don't consider going to the baths and promiscuous sex making love. I consider it the equivalent of eating junk food, and you can lay off it for a while” (Kramer, Normal 72). In Kramer's mind, gay

\footnotetext{
${ }^{17}$ This exchange mirrors Berkowitz and Callen's own rhetorical question from a couple years prior: "If sex is liberating, is more sex necessarily more liberating?" (39).
} 
sex is like junk food as it is "irresponsible because it disobeys the rules, regulations, and guidelines that govern heterosexual relations" (Bergman 127). And responsibility weighs heavily throughout the play. Ned constantly reinforces heteronormative values, particularly where sex is concerned, and blends the hegemonic discourses of shame, guilt, and responsibility as he challenges the gay community's use of sexual liberation as a marker of social identity; "When are we going to admit we might be spreading this?" Ned argues. "We have simply fucked ourselves silly for years and years, and sometimes we've done it in the filthiest places" (Kramer, Normal 94).

Kramer's cries for sexual abstinence essentially amount to calls for monogamy as The Normal Heart pairs Ned with Felix in an attempt to show Ned rejecting the ideology of the bathhouse in favor of a more heteronormative coupling. As John Clum contends in Acting Gay, "Kramer uses the Ned-Felix relationship to show what was wrong with gay relationships in the age of liberation and how old, self-destructive behavior patterns doom current partners" (76). And yet, by killing Felix in the play's closing scene only moments after he and Ned are symbolically wedded, Kramer boxes his ideology into a corner. Clum argues, "Kramer has trapped himself in his own rhetoric. There is no space for resolution of the crisis that obsesses him, no space for the love that could be a counter to the promiscuity he excoriates as not only exploitative and destructive ... but now also deadly" (76). Instead of offering some sort of ideological resolution within the confines of the play, Kramer instead chooses to confront the harsh tragic reality of the AIDS epidemic - lovers die and leave those they loved behind. And yet this resolution is symbolic as well-as Kramer emphasizes the future when Ned recounts the over six hundred young gay men and women participating in Yale's Gay Week, with their bodies full of future and promise set in contrast with the loneliness Ned felt both at Yale in his youth 
and in the closing moments of the play when he holds the hand of his dying partner. There is no real safety in monogamy, certainly not as a form of cultural identity, because monogamy can leave you just as alone as promiscuity in the time of AIDS. Within Kramer's The Normal Heart, "devotion," writes Richard Goldstein, "is the ideal poised against the twin realities of promiscuity and hostility from the world at large" ("Implicated" 308). And yet even devotion, including devotion to only one partner, cannot offer salvation from a virus that has no regard for or interest in morality.

For Kramer, the central conflict of the gay community was their positioning of sexual freedom as the foundation for gay identity, community, and liberation (both sexual as well as from the constraints of heteronormativity). Instead of focusing on those civil rights issues that were positioning gay men as outsiders within their own country, the gay community spent the decade following the Stonewall riots sleeping around, and protesting anyone who said they could not or should not. The Normal Heart brings this conflict front and center when Ned challenges Mickey and Bruce and the point-of-view they have come to represent. "The gay leaders who created this sexual-liberation philosophy in the first place have been the death of us," Ned rails at them. "Mickey, why didn't you guys fight for the right to get married instead of the right to legitimize promiscuity?" (78). Kramer does not see heteronormativity as something from which to be liberated, rather something to which the gay community should aspire.

Kramer's position allows for victim-blaming by arguing that, if gays had fought for marriage and other civil rights, they might not have been dying from AIDS. In order for Kramer's argument to work, however, he must ignore the reality of the AIDS epidemic - the virus had no regard for social establishments like marriage or monogamy—in favor of an imaginary queer-friendly America. In this way, though Kramer is essentially arguing for 
monogamy over promiscuity, he is using the language of the homophobic hegemony and losing the argument within both a gay community that desires sexual freedoms and a straight culture that does not want to grant marriage and other civil rights to the sexual deviants of the gay community. For example, when Kramer contends that Vito Russo was killed by gay men who could not come together to properly combat the AIDS epidemic, he means something quite different than noted homophobe Patrick Buchanan's statements that gays are killing themselves because of "their suicidal appetites" (qtd. in Edelman "Mirror" 24). Lee Edelman argues that although there is a difference between Kramer and Buchanan's positions, the framing ideologies rely on the same structures, "structures that make it easy_-indeed, that attempt to make it natural - to represent the gay community as murderous in its attachment to 'narcissistic' gratification" (“Mirror” 24, emphasis his). Moreover, David Bergman critiques Kramer's ideology of AIDS contending, "For Kramer, gays achieve 'respectability' by imitating the disreputable heterosexuals who deny gays their rights" (135), an argument that connects back to Bergman's critique of Kramer's junk food analogy. Kramer, Bergman continues, "struggles with the illusion that somehow marriage will protect people from AIDS ... Kramer never quite sees that promiscuity may result as much from searching for a pseudo-spouse as from avoiding the commitment of a relationship" (135). It would seem that while Kramer's call for monogamy here is a historical one_-a game of "what if?" that posits how different the 1980s might have been had the gays of the 70's behaved differently — the ideological underpinnings still require an overlooking of the sexual relations that factor in prior to the establishment of a marriage or monogamous commitment.

Tony Kushner is less critical of the choices made by the gay rights movement before the epidemic than Kramer tends to be. In his introduction to collected edition of The Normal Heart 
and its sequel The Destiny of Me, Kushner argues that Kramer's two plays

offer a persuasive account of a critical, terrible era when an emergent community, laboring to set itself free from centuries of persecution and oppression, was blindsided just at the moment of a political and cultural attainment of some of its most important goals by a biological horror miserably allied to the world's most murderous influence, its masked and its naked hatred. (vii)

Kushner speaks to the changing reality of gays in America coming out of the late 70's and early 80 s. While many gay politicians, or those in other government/political positions, remained in the closet, there were still progressive, forward-thinking movements taking place around the country, including the election of openly gay candidates to political office. Kushner still critiques Kramer's ideological ties, however, by arguing "the monogamy-versus-promiscuity model is clearly inadequate to our purposes, and if Kramer relies too heavily on such a model, then criticism is appropriate, but not a rejection of his anguished call for personal responsibility" (xxii). Kramer wants the gay community to acknowledge its own role and position within the epidemic, as well as prior to the start of the spread of AIDS, and though his critics often brand him homophobic, Kushner will not go that far, instead arguing for the value of Kramer's overall argument and art.

Kramer's harsh criticism extended beyond the gay community, and openly placed the blame for the AIDS epidemic on the "white, middle-class, male majority" (Reports 178). When Kramer spoke at a symposium for the New York Civil Liberties Union in 1987, he argued that had certain civil rights denied to gays (rights like marriage, children, joint property with a samesex partner, etc.) never been withheld, the AIDS epidemic would have been a different thing entirely. "Had we possessed these rights you denied us, had we been allowed to live respectably 
in a community as equals," Kramer argued, "there would never have been an AIDS" (178). And while this is ostensibly about community, equality, and the right to love, Kramer cannot help but bring back the anti-promiscuity argument (and take a not so subtle jab at the sex drive of the gay community): "Had we been allowed to marry, we would not have felt the obligation to be promiscuous" (178-179). Kramer's loaded phrasing here includes the word "obligation," as though the gay community had no choice but to be promiscuous in the face of a homophobic hegemony that blocked their rights at every turn. Kramer frames the ideology surrounding AIDS as a potential solution to AIDS - though once again framing it in a historical context (had this or this happened, then such and such would not have come to pass) — ignoring the underlying reality that monogamy cannot cure the sick. Yet Kramer seems to stick to his ideal of monogamy (and possibly celibacy) as the most assured way of bringing the epidemic to a halt. Moreover, this argument insists that there is some sort of moral failure in being sexual liberated, as though Kramer supports the heteronormative insistence that the only correct way to live is in celibacy or monogamy, and attempts to venture beyond those options are morally questionable and then somehow worthy of punishment (in this specific case, death at the hands of AIDS). For Kramer to be able to create an imaginary fantasy wherein the gay community could have lived "respectfully $[\ldots]$ as equals," he must ignore the reality that AIDS is amoral and not bound by any constructs of cultural morality.

\section{DEVELOPING COMMUNITY IN THE NORMAL HEART}

From the opening pages of The Normal Heart, where Kramer sets a portion of the W.H. Auden's poem "September 1, 1939" as the play's epigraph from which Kramer takes his title, it is apparent that themes of belonging and community are foundational to what Kramer wants to 
say about the struggles of the gay community in the midst of the AIDS epidemic. Kramer invokes what Auden calls "the romantic lie" and "the lie of Authority" in the second selected verse of the poem:

There is no such thing as the State

And no one exists alone;

Hunger allows no choice

To the citizen or the police;

We must love one another or die. (qtd. in Normal 5)

It is, as Kramer and Auden both recognize, a beautiful lie to think that everyone is treated equally by our society, by its peoples, and its governments, and those in need are always given the assistance they require. Rather, people in the gay community were isolated and dismissed from the general populace specifically because they were gay, and the medical advances, testing, and treatments that were sorely needed in the early days of the epidemic went unanswered as a result. Emma expresses her understanding of this through fear: "I'm frightened nobody important is going to give a damn because it seems to be happening mostly to gay men," she tells Ned. "Who cares if a faggot dies?" (22). Rather than the fear of the actions of the homophobic culture and institutions, Emma gives voice to the gay community's fear of inaction. As outsidersdangerous disease-ridden foreigners amidst the citizenry — the gay community does not share in the protection and rights of the homophobic hegemony. The visibility gained by the gay rights movement since the Stonewall riots is not enough to shift their position from outsider to citizen. As Shane Phelan argues, there is more to it than simple visibility: "A group that is consistently present only as the opposite or the outside of the nation, that has no part in the national imaginary except as a threat, cannot participate in citizenship, no matter what rights its members 
have come to enjoy" (7). ${ }^{18}$ And it is this inability for participation and protection, solely on the basis of sexual identities, that stifles public support and interest in the AIDS epidemic, and more importantly, in any efforts to bring it to a close.

For Kramer, the refusal to treat gays as members of the citizenry is a fundamental ideological component impacting the struggling gay rights/health movement developing in the 1980s. From this challenge comes several logical extensions: some lives are worth more than others; it is moral to discriminate on the basis of sexual activity; decisions should be made in the effort to protect the good (and in good-standing), not outsiders / deviant threats. This idea surfaces quite clearly when Ned meets with his heterosexual and borderline homophobic brother Ben to beg for financial and political assistance with the epidemic, a request falling on deaf ears:

BEN. My agreeing you were born just like I was born is not going to help save your dying friends.

NED. Funny — that's exactly what I think will help save my dying friends.

(Kramer, Normal 61)

Ned recognizes, and demands that his brother do so as well, that one of the major ideological roadblocks in the struggle against AIDS is the perception that gays are different, somehow lesser and therefore unworthy of the powers and protections of the mainstream culture. As Ned insists that change will come when those with political power and agency recognize the humanity and personhood (the same conditions heterosexuals were born into) of those in the gay community and accept them as equal participants/citizens and not outsiders.

\footnotetext{
${ }^{18}$ Phelan defines national imaginary thusly: “By 'national imaginary' I do not mean to posit one way of thinking in which all members of a nation participate, but rather the persistent cluster of images and rhetoric that, however inadequately or imperfectly, signal to a population who and what it is" (7).
} 
Compounding the struggle for recognition is how many in the gay community repeatedly reinforced their separation from the active body politic and their own stereotypes of foreignness. Kramer uses The Normal Heart to show how the struggling gay leadership would insist they are not political subjects - that is, their identities are not derived from their politics, or their ability to operate within the political realm. Yet more realistically this positioning belied an inner truth that the gay community was really only concerned with the way they were being treated politically when it directly impacted them.

BRUCE. We're not activists.

MICKEY. If you're not an activist, Bruce, then what are you?

BRUCE. Nothing. I'm only in this until it goes away. (44)

Bruce, like so many others in the gay community during the epidemic, had no extended interest in the political realm of gay activism, and preferred to stay out of it whenever possible. In one sense, defining one's political position on the basis of sexuality was limiting, boxing identity into the existing ideological structures that interpellated the queer subject. But in another sense, developing out of the first, this also meant these characters and their real-life analogues could rely on their privileged positions as white men within the hegemony as they had historically done so, essentially ignoring the ways in which their sexuality denied them access to certain protections otherwise afforded them. ${ }^{19}$ As Alan Sinfield argues, "These men have no tradition of political dissidence. They had not expected to need the State, and when they do they cannot quite believe that it is not on their side" (Out 323). Moreover, since the gay community was loosely knit primarily on the basis of sex acts, politics and political agendas threatened to fracture their

\footnotetext{
${ }^{19}$ Kramer, by developing a political argument that allows for temporary activism that focuses solely on the primary area affecting white gay men, erases the presence of the non-white gay man within the gay community.
} 
already tenuous bonds. When Bruce tells Ned that their health organization has to stay away from acts that might be deemed political, Ned challenges the possibility of such a response: "I think it's going to be impossible to pass along any information or recommendation that isn't going to be considered political by somebody" (Kramer, Normal 55, emphasis his). Such conflicts only served to reinforce the community's separation from, as well as struggle to operate within, the mainstream political realm.

Kramer uses the City Hall meeting with Hiram Keebler, the mayor's assistant, in Act Two to perfectly encapsulate the struggle for citizenry and equality, as well the manners through which the gay community was denied access to, and the support and protection of, those political institutions tasked with protecting its citizenry. By relying too heavily on the faults and errors of the Mayor's office, Sinfield contends, the play "blames the system rather than critiquing it" (Out 322). Nowhere is this blame more evident than when Kramer has his protagonists repeatedly correcting the mayor's aide-Hiram's own position of influence is one full of willful ignorance when it comes to gay equality/health issues. When Hiram says it is "illegal discrimination" to not rent office space to their AIDS organization, Mickey "nervously" corrects him, "Mr. Keebler, sir, it is not illegal to discriminate against homosexuals" (Normal 79). When Hiram insists that he cannot tell the mayor that there is an AIDS "epidemic" going on "because it isn't true," the men have to correct him:

MICKEY. The Centers for Disease Control in Atlanta declared it. TOMMY. Seventeen months ago.

NED. How could you not know that?

HIRAM. Well, you can't expect us to concern ourselves with every little outbreak those boys come up with. And could you please reduce the level of your hysteria. (80) 
Hiram's shifting of the blame to other institutions (e.g. the CDC is full of reactionaries, much like you hysterical queens) subtly invokes Ned, Mickey, and the community's outsider statuses: were they a functioning and important part of the system they would know this. And though Kramer may not be fully critiquing the system (I would argue that Hiram's willful ignorance and overall disdain is itself a form of critique), he is certainly condemning it for excluding the gay community in their hour of need.

More than just participating in the political and medical fight for recognition, Kramer also criticizes the gay community's willingness to come out and be recognized on a social level as gay men living and dying as family, friends, and co-workers. Recognition, public outing as it were, is not enough on its own, but it certainly is a powerful step towards gaining cultural acceptance, and by extension the political status of equality that comes with membership in the citizenry. In this sense, Kramer regularly makes connections between gay men during the AIDS epidemic to the struggles of the Jews during the Holocaust; Kramer was unwavering in this comparison, even publishing a collection of writings about AIDS in the 1990s as Reports from the Holocaust. In The Normal Heart, Ned realizes that even though people walked with so little resistance to their deaths in the Nazi camps, at least they claimed their identities while doing so:

NED. Is this how so many people just walked into gas chambers? But at least they identified themselves to each other and to the world.

BRUCE. You can't call people gay who don't want to be.

NED. Bruce—after you're dead, it doesn't make any difference. (108) This social divide leads to Ned's dismissal from the group, mirroring Kramer's own departure from GMHC, as Ned, giving voice to Kramer's own concerns, argues that the gay community has a responsibility to itself in the face of AIDS, and that resistance starts with open and public 
acknowledgement of their own sexualities. After Bruce reads Ned's dismissal letter, Ned opts to speak instead of the potential depth and wealth of what gay culture and identity can actually be when it no longer relies solely on sexual behaviors but also includes in its definition part of heteronormative culture: "I belong to a culture that includes Proust, Henry James ... Plato, Socrates, Aristotle, Alexander the Great, Michelangelo, Leonardo da Vinci ... Walt Whitman, Herman Melville, Tennessee Williams ... these are not invisible men" (109). He continues, “The only way we'll have real pride is when we demand recognition of a culture that isn't just sexual" (110). For Kramer, the key for accessing the benefits and protections of being treated as equal citizens comes from the gay community changing its image and public perception, an act that begins with coming out and claiming a gay culture, and their role in straight culture, as their own. Visibility is, in Kramer's estimation, the means through which the gay community can properly receive public acknowledgement, support, and treatment in the battle against the AIDS epidemic.

Kramer's cries for the gay community to take ownership of AIDS come in direct and immediate response to those members of the community who were ignoring the diseased and dying in its midst, and stressed the collectivity of the gay identity. In this sense, Sabrina Huettner recognizes that Kramer "calls for collective struggle against AIDS in the face of an all-pervasive individualistic culture" (269), notably expressed in the gay community's unwillingness to fully bind together to organize and fight. However, this culture of individualism, this ideological structure that values individual immediate sexual pleasure over general cultural health, is not exclusive to the gay community, and in reality reveals how much, when it comes to selfpreservation, like the mainstream culture they really are. As George Newtown writes, "Gays who die of AIDS rather than give up sex behave just like any other moderns for whom sex is more 
important than life itself' (210). Newtown recognizes the role of the AIDS play (Kramer's The Normal Heart and William Hoffman's As Is, more specifically) in addressing this issue on a national stage. "The AIDS dramatists," Newtown argues, "help raise consideration of sex (by both gays and straights) to the level of social responsibility: a responsible choice about sex can help remove the specter of death from the entire society" (221). Kramer uses The Normal Heart to rewrite the differences and remove the otherness/foreignness that surrounded the gay community during the AIDS epidemic, arguing that the AIDS epidemic, though it seemed primarily to affect gays, is our culture's shared responsibility. Unfortunately for Kramer, every time he tried to move the gay community into closer alignment with the heteronormative hegemony, his own community branded him a homophobe and traitor.

This separation between Kramer and the gay community can be seen as far back as July 1985, when Richard Goldstein published "Kramer's Complaint" in the Village Voice. Goldstein himself walks a fine line, offering praise for Kramer's play while simultaneously challenging the anti-promiscuity ideology it proffers (a challenge he notes that many of those in the gay press support). Kramer's negative reviews in the gay press and positive reviews in the straight press stem from how, through The Normal Heart, "Kramer tells straight people it's okay to support gay rights while condemning the way we live" (20). "This isn't a play about AIDS," Goldstein argues, "it's about being gay, and the anger it elicits has more to do with gay sex than with any health crisis" (20). The gay community, and specifically the gay press that Goldstein is alluding to, read Kramer's efforts at removing the stigma of otherness as condemnations of their hardfought and cultural-defining sexual freedoms. Naturally Kramer's ideological demands struck a nerve, putting the gay community on the defensive; "AIDS forces gay men to confront the collective consequences of personal behavior; it forces us to relate communal consciousness to 
survival" (20). Like many other critics, John D'Emilio intermingles Kramer's personal life and ideological beliefs with those of his characters. D'Emilio argues that Kramer has, over the years since co-founding GMHC and ACT UP, become "a figure with cultural capital at his disposal" (84). However, it is Kramer's own overriding position within queer culture, what D'Emilio calls “cultural critic as outsider" (84), that limits the ultimate extent of Kramer's ability to promote and reinforce strong, active queer community bonds. "Perhaps," D'Emilio argues, "this tells us something about the state of the movement even after the enormous growth and institutionalization of the last ten years. The person associated with the movement who has as much visibility as anyone remains an outsider" (84).

\section{ANTICIPATING KUSHNER}

AIDS, as Sontag wrote, "brings to many a social death that precedes the physical one" (34). This social death at times manifested itself through the (often homophobic) ideologies surrounding AIDS that created an imaginary identity for its gay subjects, one that reinforced the position of the gay individual as a stranger/foreigner, demanding isolation and inoculation from the threat of (cultural, medical, and moral) contamination. And while medical advancements in the treatment of HIV have reduced the mortality rate overall, what Sontag hailed as a social death in 1989 still remains for some. David Caron, writing in 2014, argues "In many ways, the inevitable physical death that HIV infection once signified in pretty much everyone's mind has now been replaced by a vicious, pernicious social death, all but ensuring that if people don't die of AIDS, somehow they still do" (Nearness 120).

Kramer's attempts at challenging the ideologies that denied citizenship, equality, and care for the gay community came at the expense of his own position within that community and 
revealed its deep ideological divides. Those divides revolved around challenges to how the gay community defined itself: was it the sexual acts and freedoms that established it, or could other avenues for community building (culture, art, taste, etc.) be considered? Kramer's call for the gay community to abandon those philosophies premised on sexual freedom as a way of life was met with resistance from a gay community that read his calls for action as homophobic and heteronormative, and Kramer was forced to ignore the amoral nature of the virus in order to advance an ideology that denounced sexual liberation as the defining force behind the gay community. Kramer did argue, however, that the path for equality required shifts in actions and behaviors to recognize the role of AIDS in altering the shape of the discourse surrounding gay identities and bodies. Like Kramer, Tony Kushner will also reimagine how to build a gay community apart from gay sexual activity, but Kushner comes across as less combative than Kramer, presenting instead a progressive fantasy that simultaneously promotes homonormativity while offering a means to critique and adapt it. 


\section{Chapter Two}

\section{"Everybody's Got to Love Something":}

AIDS Fantasies, Both Prophetic and Ideological, in Tony Kushner's Angels in America

You can't live in the world without an idea of the world,

but it's living that makes the ideas. (Kushner 278)

Despite the similarity of an overarching theme (that is to say, they both are models of the gay AIDS play) shared by both Larry Kramer and Tony Kushner's plays, they have rarely been analyzed in a meaningful way together. One of the more significant essays to consider both plays together is Peter F. Cohen's “Strange Bedfellows: Writing, Love and Politics in Angels in America and The Normal Heart." ${ }^{20}$ Cohen, like many other critics, glosses over the ideological foundations of the play(s) and focuses on more specific moments, themes, or concepts (a great number of essays have been written examining religion in Angels in America, for example). Taken together Kramer and Kushner's plays allow for a more nuanced discussion of who and what precisely constitutes the foundation of the gay community and of gay identity on an individual level. And so my concern here is less with the plot challenges Kramer and Kushner's characters face and more with how those challenges (and the character's responses to them) help us understand what it means to be gay in America—regardless of whether or not one sees themselves as members of that community — during the time of AIDS.

${ }^{20}$ Cohen focuses on the difficulties involving resolving plot issues in plays that mix the romantic with the political: "The love plot in a drama might be resolvable ... the struggle against AIDS cannot be" (198). 
Similar to Kramer, playwright Kushner used the stage to process and publicize the physical, emotional, and spiritual challenges the gay community experienced throughout the onset of the AIDS epidemic. Kushner's almost-immediate-classic play Angels in America was initially released in two parts (Millennium Approaches and Perestroika) in the early 1990s, and focused essentially on the relationships of couples living in New York City in 1985, as AIDS was sweeping through the city. In the play, Prior Walter, an HIV-positive gay man, is dumped by his boyfriend Louis (who just can't handle all the pain and pressure that comes with the disease), and sees a vision of an angel who brings Prior prophetic visions of the past and future. Although Kushner uses a modified, "fictionalized" version of Roy Cohn to offer the play a clear antagonist/villain, much of the essential conflict of the play stems from Prior's inner conflict in processing his own mortality as well as the prophetic visions which may or may not be the feverish, delusional side-effects of his failing health.

Angels in America garnered a Pulitzer Prize, as well as won two Tony awards for Best Play (in consecutive years, one for each part), in no small part due to its user-friendly heteronormative view on gay male sexuality that establishes equal parts blame and acceptance. Jacob Juntunen argues that Angels in America's success can be seen in how "it took an emergent ideology and was able to make more accessible and digestible an oppositional program. . . It was successful precisely because it was a mainstream, for-profit production. Its political work was not in spite of its position in the 'culture industry,' but because of it" (40). Juntunen is drawing off of Raymond Williams" use of residual and emergent ideologies and "what they reveal of the characteristics of the "dominant"' (Williams 122). Where residual comes from the past, the term emergent ideologies means "that new meanings and values, new practices, new relationships and kinds of relationship are continually being created" (123). This focus on social 
bonds of relationship is continued as Williams emphasizes that such ideologies involve "the formation of a new class, the coming to consciousness of a new class, and within this, in actual process, the (often uneven) emergence of elements of a new cultural formation" (124). For Kushner then, this emergent ideology develops with a new class of public homosexual, divorced from prior concerns of clout and power (as embodied by Cohn) and more focused on establishing a queer community tied together by bonds of friendship and mutual desire for progress rather than romantic fulfillment.

Kramer and Kushner's plays struggle to process the Real of AIDS, the empty space in our reality that the ideologies of the times cannot hold or understand. For Kushner's part, Angels in America argues that the great historical push of progress would be the key for establishing an oppositional ideology, and this queer progress is itself a form of prophecy that seeks to offer a resolution to the struggles made manifest by the AIDS epidemic. If the dominant ideological forces insist gay=death, then Kushner seeks to use queer progress to promote a prophetic ideology that reads gay=life. But like Kramer, Kushner's ideological fantasy relies on the power of a prophet to change, replace, or reform "immoral" sex acts; though, unlike the realism that grounds Kramer's text, Kushner's prophet is a fantastical one of Biblical proportions. At its core, Angels in America is Kushner's attempt to deal with the unassimilable grief that comes from the gay community's confrontation with an unassimilable virus by constructing a fantasy; even though Kushner might wish his gay fantasia were not a fantasy, nevertheless it remains one, and neither Kushner's wire-bound angel nor his lost prophet can make it otherwise. These fantasies speak to the playwrights' attempts to define the gay community through means that do not rely solely on the sexual, but rather ones based on shared communal experiences, and in turn, redefine the relationship between the homo- and hetero- cultural structures. 
And while Kramer's play focused on the cultural and political positioning of gays as strangers/outsiders/threats in their own country, Tony Kushner's Angels in America was still tackling that ideological divide several years later. Moreover, Kushner's play examined closely, and argued for, the specific notion that gays are outsiders precisely because they strive for a forward progress that is seen as immoral by those outside their own community. Within the gay community, these approaches were critiqued for being (chrono)heteronormative, essentially asking the gay community to subscribe to the hetero-oriented structures endorsed by the hegemony. Kushner's play takes on the form of a complicated fantastical approach, challenging perceptions of time and space, while making the argument for a repositioning of the gay community as citizens rather than outsiders.

\section{PROGRESS AS OPPOSITIONAL IDEOLOGY IN ANGELS IN AMERICA}

Tony Kushner's own writing about the AIDS epidemic varied greatly from the stark cold realism of Kramer's play. Angels in America approached the epidemic through the fantastical lens of religion, spirituality, and prophetic visions. The gay community, represented most clearly in the form of Kushner's prophet Prior Walter, strives for a forward progress towards changeaway from the homophobic, heteronormative systems of the past that kept them oppressed and viewed them as dangerous, potentially deadly, outsiders/foreigners. Kushner develops his ideal for a gay community through a use of mysticism and spirituality, a blending of religion and fantasy that provides a separate space for his progressive vision. But Kushner's use of the fantastic to craft his ideological fantasy through which he can attempt to process the unprocessable horror of the AIDS epidemic means that he must constantly ignore the reality that no such fantastical spiritual realm of angels actually exists. Moreover, the use of prophecy, and 
Prior's ultimate rejection of it, presents a possibility for a movement through and adaptation of the heteronormative structures demanded by the hegemony.

Kushner's play garnered much of its inspiration from the works of Walter Benjamin (from whom Prior takes his last name), specifically Benjamin's studies on futurity and the concepts of moving forward while simultaneously looking back at what had come prior. David Savran, in his foundational essay "Ambivalence, Utopia, and a Queer Sort of Materialism: How Angels in America Reconstructs the Nation," looks closely at Benjamin's (and in turn, Kushner's) interest in Paul Klee's painting Angelus Novus, a work that features the "angel of history" moving forward in time while facing back, staring in shock and awe at the rubble of history. Discussing Benjamin's take on Klee's painting, ${ }^{21}$ Savran argues, “In Benjamin's allegory, with its irresolvable play of contradictions, the doggedly well-intentioned angel of history embodies both the inconceivability of progress and the excruciating condition of the Now" (“Ambivalence" 17). Benjamin's allegory is, Savran postulates, "the primary generative fiction for Angels in America" (17), and the angel of history has clear overlaps with the angels of Kushner's play who bemoan the progression of time that has led to the departure of their creator

${ }^{21}$ Writes Benjamin in his "Theses on the Philosophy of History": "A Klee painting named 'Angelus Novus' shows an angel looking as though he is about to move away from something he is fixedly contemplating. His eyes are staring, his mouth is open, his wings are spread. This is how one pictures the angel of history. His face is turned toward the past. Where we perceive a chain of events, he sees one single catastrophe which keeps piling wreckage upon wreckage and hurls it in front of his feet. The angel would like to stay, awaken the dead, and make whole what has been smashed. But a storm is blowing from Paradise; it has got caught in his wings with such violence that the angel can no longer close them. This storm irresistibly propels him into the future to which his back is turned, while the pile of debris before him grows skyward. This storm is what we call progress" (257-258). 
and their ongoing state of misery. Savran, continuing his analysis in "The Theatre of the Fabulous: An Interview with Tony Kushner," argues, "For Kushner, the angel of history serves as a constant reminder both of catastrophe (AIDS, racism, misogyny and homophobia, to name only the most obvious) and of the perpetual possibility of change, the expectation that, as Benjamin puts it, the tragic continuum of history will be blasted open” (131). In Kushner's fantastical conclusion of the first half of Angels in America, the angel's arrival, which literally tears the roof off, reflects both catastrophe and promise and the angel symbolizes both epidemic and cure.

Kushner himself has made the connections between the angel's catastrophic arrival and the epidemic's explicit one, openly connecting the progressive futurity of Angels in America with Benjamin's reflective angel of history: “As Walter Benjamin wrote, you have to be constantly looking back at the rubble of history. The most dangerous thing is to become set upon some notion of the future that isn't rooted in the bleakest, most terrifying idea of what's piled up behind you" (qtd. in Savran, "Theatre" 140). It is, of course, this challenge of progress that drives the narrative while simultaneously immersing the play in a culture war that sees amoral/immoral (read as "anti-Christian" or even "anti-Conservative") art as chaos. As James Fisher points out, "conservatives like [Pat] Buchanan and [Allan] Bloom are fixated on a vision of a once homogenous past (real or imagined) and deny that society is in a continual unstoppable process of change" ("Advantage" 123-124). Moreover, a conservative view of art and culture generates a nostalgic look at the past—-the glory days of modesty and moral hygiene — rather than seeing it as a disaster of epic proportions. Initially, Kushner's prophet Prior, like the Old Testament prophet Jonah, also resists this call of progress, chalking up the angelic visitations to his illness, though Belize, Prior's friend (and the play's voice of reason/reality), is having none 
of it. "This is not dementia. And this is not real," Belize angrily tells him. "This is just you, Prior, afraid of what's coming, afraid of time. But see that's just not how it goes, the world doesn't spin backwards" (Kushner 181). Belize recognizes the ways in which a conservative, heteronormative vision of a past threatened by the future has been culturally inscribed on Prior, but also denies Prior any prophetic abilities or the reality of any angelic visions, rather seeing them as the product of fear and uncertainty in the wake of Prior's partner Louis's departure.

Kushner's reliance on the theories of Walter Benjamin and his contemporary Bertolt Brecht helps to call attention to the necessary fiction/fantasy of the Angel. This is why Kushner's stage direction that the audience should be able to see the wires is so important:

The moments of magic - the appearance and disappearance of Mr. Lies and the ghosts, the Book hallucination, and the ending — are to be fully realized, as bits of wonderful theatrical illusion - which means it's OK if the wires show, and maybe it's good that they do, but the magic should at the same time be thoroughly amazing. (11, emphasis his) While the audience can be impressed with the technical presentation of the fantastic, they should never believe in the angel despite the beliefs of the characters within the play (notably Prior). "The spectator," Brecht argued in his critical writings on the theatre, "was no longer in any way allowed to submit to an experience uncritically (and without practical consequences) by means of simple empathy with the characters in a play. The production took the subject-matter and the incidents shown and put them through a process of alienation: the alienation that is necessary to all understanding" (71). Kushner's use of Brechtian strategies of epic theater allow the play to break the fourth wall, and as such we can more clearly see that the Angel is a fantasy exposed as a fantasy. Mark Wing-Davey, a director of a 1994 stage version of Angels in America, noted, "the irony of the play is that the angel is not particularly helpful $[\ldots]$ And we're playing with 
people's preconceptions of what angels are, and do" (qtd. in Evenson E2). This is, of course, precisely what Brecht (and Kushner) want. The disconnect between the audience's preconceived notions of what angels are and the angel presented onstage serves to further alienate the audience and critique the fantastical within the play. As Brecht argues, "To alienate an individual in this way, as being 'this particular individual' and 'this particular individual at this particular moment', is only possible if there are no illusions that the player is identical with the character and the performance with the actual event" $(195$, sic). The wires attached to the angel remind the viewer of the reality that the angel is in fact a person being suspended, removing the foundation of the illusion of theatre (something that could only happen in Kushner's form of epic/alienation theater, as opposed to Kramer's form of realist theater), a visual reminder/manifestation of Belize's disbelief in angels and Prior's prophetic status.

More than just the supernatural presence of angels, Kushner plays with the constraints of time and space as he develops his fantasmic ideology. And if at first blush it seems that Kushner is reinforcing the construct of gay-as-outsider through the use of Prior as a prophet, the play destabilizes this point-of-view through the use of a space, shared by both Prior as well as the heterosexual Mormon housewife Harper, set apart from the strict reality of heteronormative, hegemonic time and space. Prior and Harper, each one-half of the two primary couples that drive Angels in America's narrative, meet each other for the first time in "the threshold of revelation"; in the stage directions to the scene (act 1 scene 7), Kushner calls this a "mutual dream scene" and writes that Prior is having a dream while Harper is having "a pill-induced hallucination" (36). Prior is in her hallucination or Harper is in his dream; the directions allow for either or quite possibly both options to be correct, though the characters themselves seem certain that their own dream-space has been invaded by the other. "I'm not in your hallucination. You're in my 
dream," Prior tells Hannah, in response to her questioning his presence in her medicated state (37). Their shared space is what Harper calls "the very threshold of revelation" (39), a concept Prior echoes throughout the play (most notably when he uses it to reveal his prophetic nature to Louis through the knowledge that Joe is a Mormon, a fact he learned from Harper in the threshold [217]).

While Harper's presence in the threshold challenges any strict readings of gays as outsiders, the space certainly allows for and promotes a queer space set apart from the heteronormative mainstream. In this sense, it is not because gays represent the Other, but rather that the play posits the possibility of a (imaginary) space where the gay community is not othered. And while the play struggles with the threshold's imaginary status, by creating that space Kushner is at least attempting to construct an alternative means of community-building, apart from gay sex acts. Yet such a possibility still takes time for the characters to process. Harper and Prior's initial introductions situate both of them as outsiders - others (Harper with her religion and Prior with his sexuality) — set apart from the ideals of the hegemony and each other.

HARPER. I'm a Mormon.

PRIOR. I'm a homosexual.

HARPER. Oh! In my church we don't believe in homosexuals.

PRIOR. In my church we don't believe in Mormons. (Kushner 38)

Harper's use of "homosexuals," referring to the people not the sexual identity (homosexuality), implies a categorical erasure of homosexuals from her belief system / church, clearly marking them as fantastic fables/others. But she still retains some general cultural knowledge of homosexuals, if only to know she does not support their existence. Harper, confused about the 
space she shares with Prior, seems to think imagination is limited by the one doing the imagining: "Imagination can't create anything new, can it? ... Nothing unknown is knowable" (38). Harper contradicts herself by arguing that they are in a special, specific place- - the threshold of revelation where "you can see things" (39), and certainly both she and Prior see things there. Harper's interpretation of the threshold (and seeing Prior as a manifestation of her imagination) means that when Prior tells her "your husband's a homo" (39), it is a revelation that at first she is startled by but then allows herself to accept, possibly as something she had long suspected though never allowed herself to say aloud. This creates an important distinction between what is going on with Harper and Prior in the threshold of revelation and Harper's earlier hallucination of Mr. Lies (Act 1 Scene 3), a hallucination that we can understand does not take place in this threshold. Harper cannot quite work out that Joe is a homosexual (a realization she cannot come to until Prior reveals it to her in the threshold).

After Harper leaves, it is in the threshold where "A Voice" first speaks to Prior, calling for him to "Prepare the way!" (41), much like John the Baptist was called to prepare the way for Christ in the gospels. Una Chaudhuri reads Prior's call to prophesy as a reimagining of what has come before: Prior "must not merely write a new history—-the history of the future cannot be written — but invent a new historiography, a new mode of relating past to present and future. A crucial insight of the 'threshold of revelation' is that imagination is constrained by history" (254255). In this sense, Prior is not some new breed of prophet, divorced from the historical line of prophets who came before him, but is influenced by and contained within the limits of those prophets who have come before him in history. (Act Three of Millennium Approaches reinforces how Prior is bound up in history when he is visited by two previous incarnations of Prior Walters.) Deborah Geis reads Harper and Prior's scene in the threshold of revelation as "a 
postmodern interpretation of 'imagination': it depicts a culture in which the new is actually a series of recyclings of the old" (207). Prior is a prophet in the line of John the Baptist, and the Voice that visits him repeats that same summoning of Matthew 3:3 (itself a repetition of the summoning in Isaiah 40:3). Furthermore, Geis argues, the threshold of revelation "is both the edge or brink of Revelation and the ability to balance through one's psychic, or sixth, sense in a liminal, extrasensory space that is outside of reality, or paranormal. Prophecy is a form of insanity and vice versa" (200). The threshold represents a space set apart from our traditional understandings of knowledge and history, yet connected to and bound up in the limits of our own imaginations. Unfortunately, this reading is complicated by its own connectedness to heteronormativity: the only safe space Kushner can construct for a gay community to be formed is also one linked directly to insanity, madness, and hysteria, conditions often assigned to homosexuals and women in order to isolate them from the mainstream. ${ }^{22}$

It is the presence of AIDS (the virus and the epidemic) that redeems Kushner's attempts to thwart heteronormative structures. Where Prior's prophetic abilities foreground his own personal other-ness, Harper's presence within the threshold acknowledges the potential for shared experiences apart from (and instead of) the heteronormative hegemony that dictates their behaviors; more clearly stated, the threshold of revelation gives them a space to imagine not only an alternative view of what has come before, but also a liberated and ideologically-different

${ }^{22}$ Foucault goes into this in great depth, particularly when he analyzes how medicine sought to manage sex and sexuality: "medicine made a forceful entry into the pleasures of the couple: it created an entire organic, functional, or mental pathology arising out of 'incomplete' sexual practices" (41). Later Foucault critiqued the four primary figures ("the hysterical woman, the masturbating child, the Malthusian couple, and the perverse adult") that were the focus of analysis, restriction, and juridical controls during the nineteenth century's preoccupation with sex (105). 
future for those living with (and dying from) AIDS. As Susan Knabe argues, "Fantastical representations of AIDS suggest the possibility of alternate futures (and pasts), in part because they are able to map the limitations of imagination in relation to AIDS, a mapping which foregrounds the imbrication of history, bodies, knowledge, and the embodiment of knowledge" (216). For Knabe, fantastical representations enter Angels in America through the threshold of revelation, and that "in the case of both Hannah and Prior, the fantastical aspects of the text underscore knowledge and its transformative, indeed political, potential" (222-223). The threshold allows Prior to conceive of alternate futures — ones grounded firmly in the ideal of progress - that look at the past, not in blind nostalgia, but rather as a wreckage of injustice from which a new and better future can emerge. Kushner hopes to use the threshold of revelation as a site for promoting a fantasy that re-reads the tired heteronormative gay=AIDS=death formulas and instead offers an oppositional ideology that offers gay=life in its place.

Kushner's fantastical play cannot escape or erase, and so it chooses to ignore, the underlying principle that at its core, the threshold, like its other spiritual counterparts within the play, remains itself a fantasy. The threshold of revelation is not the solution in and of itself. To be sure it allows for a space where a different future can be imagined, but it is still separate from the existing world/culture and Prior can only enact real change by rejecting his place as prophet and embracing life, challenging the homophobic ideologies that divide the gay community and attempt to keep culture firmly rooted in its history of oppression, homophobic, and rigid JudeoChristian morality. "We can't just stop," Prior tells the angels, "We're not rocks—progress, migration, motion is ... modernity" (Kushner 263-264). And while Prior can reject God, he cannot reject that God exists or that revelation is possible. Prior actually further grounds God in reality by insisting that should the absent deity return, the optimal solution would be to sue him: 
"Sue the bastard for walking out. How dare He" (264). George Piggford critiques Prior's final decision to reject his status as prophet and return the Book to the angels, arguing that Angels in America "ultimately rejects a discourse of AIDS focused on the threshold of death. By rejecting his role as prophet, Prior forsakes his opportunity to live at the 'threshold of revelation,' a new form of being situated at the far side of life and of language" (186). Yet Prior's rejection of his prophetic status comes, not because he rejects some new form of life, but rather because he chooses life itself; "I want more life," he repeatedly tells the angelic host (Kushner 267), whereas the angels, like the old conservative ways that have come before, seek an end - a cessation- to progress.

\section{KUSHNER'S QUEER PROGRESS AS PROPHECY}

In his quest to assert the gay community's position within the hegemony, Kushner framed the progressive AIDS narrative so that the gay subject can make strides towards a heteronormative cycle of life, yielding to the structures of what Elizabeth Freeman calls "chrononormativity." Within a system of chrononormativity, Freeman argues, "naked flesh is bound into socially meaningful embodiment through temporal regulation. [Chrononormativity is] the use of time to organize individual human bodies toward maximum productivity... people are bound to one another, en-grouped, made to feel coherently collective, through particular orchestrations of time" (3). The collectively unstructured gay community of the pre-AIDS era was still finding its initial footholds post-Stonewall, and chrononormativity became one of the methods of organizing time that some in the community adopted in order to more properly conform to the heteronormative hegemony, much to the chagrin of other members of the gay community. As Freeman postulates, this process that binds bodies through the use of time 
"extends beyond individual anatomies to encompass the management of entire populations... [T] he state and other institutions, including representational apparatuses, link properly temporalized bodies to narratives of movement and change" (4). The gay community, knowingly or otherwise, fell into the chrononormative pattern that heteronormativity demands. In his epilogue, Kushner posits the potential for a post-AIDS queer identity focused less on the sexual and more on the establishment of proper familial, cultural, and sociological bonds that move a community (and a civilization) further (for example, as Angels in America ends, the play's couples are all fractured while the group remains intact). When Kushner invokes sexuality, queer or otherwise, its positioning is more closely aligned with the chronobiopolitics (what Freeman identifies as "the sexual arrangement of the time of life" [3]) of the heteronormative hegemony than with the carpe diem lifestyle of the pre-AIDS gay community. This shift extended beyond monogamy; more than a focus on the number of sexual partners, the gay community would go on to promote a conscious social coupling that developed into a nuclear family (albeit one with a same-sex couple at its center). In order to be more heteronormative, the future of gay rights embraced challenges for marriage equality and same-sex adoption rights, a progressive shift Kramer anticipates as he encourages the gay community to dream forward towards a community and world organized around life (similar to Freeman's chronobiopolitics). In no small way, Kushner seems to be embracing and endorsing a shift towards a form of heteronormativity as a means of progress for the gay community going forward out of the AIDS epidemic.

Entitled "Bethesda," the epilogue advances the play forward four years from the end of Act Five, to February 1990, and brings Prior, Louis, Belize, and Hannah together on the still fountain of Bethesda in New York City's Central Park. Kushner's epilogue, and in particular Prior's concluding speech, while seemingly written to be uplifting, also contains what Matthew 
Wilson Smith calls a "painful progressivism" that is "combined with an optimistic sort of apocalypticism" (163). Smith is clearly inspired by Harper's last lines of Act Five that close the primary body of the play: "In this world, there is a kind of painful progress. Longing for what we've left behind, and dreaming ahead" (Kushner 275). In the midst of his epilogue, Kushner presents a discussion of theory and progress, and how change comes to those who dive right inwho take action and move the world forward. "You can't wait around for a theory," Louis tells the audience (278). Belize and Hannah concur, and Hannah tells them, "You can't live in the world without an idea of the world, but it's living that makes the ideas. You can't wait for a theory, but you have to have a theory" (278). According to Roger Bechtel, Kushner "offers a theory that is also a non-theory: interconnectedness. What he avoids are the grand narratives, the unified theories that have come under such harsh scrutiny, in favor of a praxis of plurality that will, in dialectical fashion, generate its own theory" (117). Bechtel recognizes that their arguments are ongoing throughout the epilogue (and though he does not say it, would continue after the ending point of the play itself); "But in this instant in which the dialectic freezes, this momentary picture of coalition, we can imagine an articulated counterhegemony of the left" (117-118). The temporal shift forward-itself a manifestation of progress, in that Prior remains alive and hopeful of even more living to come-allows Kushner to promote a form of chrononormativity emphasizing the potential for a shared gay community, while still challenging the homophobic ideologies that present gays as outsiders obsessed only with the sexual. Although Kushner's play is far less explicit in stating its ideological ideals than Kramer's, Angels in America still makes a strong case for separating gay selfhood and identity from sexual identity. 
And though the entire epilogue addresses Kushner's ideological shifts, they really take form in Prior's closing statement. Prior, speaking directly to the audience as they do for most of the epilogue, emphasizes progress as the driving principle for the future of the gay community. And while Prior still measures time using the weather and seasons - tying human experience to the conditions that surround it - he also resists structuring it around productivity or other specific cycles of life, instead relying on life itself to be the greater ideal for fighting for. And so while Louis and Belize rattle on about the state of Israel, Prior offers his closing thoughts and wellwishes to the audience:

I'm almost done.

The fountain's not flowing now, they turn it off in the winter, ice in the pipes. But in the summer it's a sight to see. I want to be around to see it. I plan to be. I hope to be. This disease will be the end of many of us, but not nearly all, and the dead will be commemorated and will struggle on with the living, and we are not going away. We won't die secret deaths anymore. The world only spins forward. We will be citizens. The time has come.

Bye now.

You are fabulous creatures, each and every one.

And I bless you: More Life.

The Great Work Begins. (Kushner 280, emphasis his)

Prior closes Perestroika by mirroring the call of the angel at the end of Millennium Approaches, ${ }^{23}$ turning the angel's greeting into a farewell, and moving the fantastic, prophetic

${ }^{23}$ ANGEL. Greetings, Prophet.

The Great Work Begins. 
summoning into a grounded, communal blessing. At the close, Kushner creates an almost idyllic version of the future, one in which the selfish individualistic demands of his characters are replaced by harmony and an embracing of a shared collective responsibility for change and progress. Louis didn't just reject the individualistic drive within himself that led him to break up with Prior, his presence at the fountain reflects his support of Prior's forward spinning community. Yet in some ways, this ending is a fantasy unto itself, as it betrays several of the thematic and personal issues of morality and relationships Angels in America asks. Stephanie Byttebier challenges Kushner's shift here at the close: “Given the undeniably prominent position 'individualism' is given throughout Angels, it seems inevitable that we should read Prior's final utopian evocation of a civic collectivity as a deferral of rather than a solution to the problems the plays pose" (292). And yet, the epilogue might then be a challenge, rather than a solution or even a deferral, to the gay community to break free from its individualistic ideologies, notably those that lead to isolation and/or a refusal of civil, medical, or social rights.

Of course, not all critics readily embraced Kushner's notions of interconnectedness and social community as progress. Peter Cohen argues that this support for an ideology of collectivity damages the narrative success of Angels in America; "the play ends up undermining all its love stories in favor of a vision of collectivity and a call for social change" (210, emphasis his). Part of this undermining comes in the way "Kushner replaces the couple with the group" (214). Cohen continues to argue that the open-ended nature of the epilogue "helps to reverse the ideological leanings of the bulk of the play" (214). I argue that rather than reverse the play's ideological leanings, the epilogue's move towards a collective community built on mutual success and shared citizenship, rather than the selfish individualism that plagued the play's 
coupling narratives, is a literal manifestation of Kushner's call for an ideology that embraces progress rather than a promotion of the wreckage of "the way we have always done things."

Prior's call for progress is made nowhere more clearly than in his blessing, "More Life." It was, after all, this desire for life that caused him to return the Book and reject his role as prophet. James Fisher calls Prior's final statements about disease, death, citizenship, and progress "a challenge that encapsulates his guarded optimism" (Understanding 55). Moreover, when Prior

invites the audience to imagine progress that, in his case, translates to "more life," despite the ravages of AIDS and the emotional pain of abandonment he endures, he does so with his eyes firmly fixed on what lies behind him, on the stagnation of stasis. He accepts, and even embraces, the agonies of his life and, as such, achieves redemption born of a renewed hope, even if that hope is burnished with a knowledge that the joy of living is inextricably linked to loss and suffering. (Fisher, Understanding 39-40)

Fisher returns to Benjamin's Angelus Novus, recalling the overlap — not of Angel-to-Angel, but rather of Angel-to-Prior, and arguing that Prior's redemption can be found in an acceptance of history balanced with a living hope for the possibility of progress. "We live past hope," Prior tells the council of angels (Kushner 267), and "More Life" reflects and reinforces his own call for progress in the wake of suffering as opposed to the angels' request for cessation of life instead. Claudia Barnett reads the declaration "More Life" as Prior's prophecy (in direct counter to Harold Bloom's comment that Kushner's "gay prophet simply has no prophecy to give us" [Bloom 72]), when she argues, "Prior's prophecy is that AIDS must not equal death" (Barnett 479). She explains further, "the route to more life is through Purgatory. Purgatory is AIDS, and, as Angels affirms, AIDS is a condition of life" (480). In this sense, Kushner's ending also rejects 
the homophobic discourse of the hegemony that reads AIDS as not only a death sentence, but also as a punishment for a violation of natural, moral sexual acts that promote a clear structure of societal bonding (organized around the generation and reproduction of the monogamous family unit).

Kushner presents a clear call for a gay community that can — and should — transform itself in the wake of the AIDS epidemic, embracing its generative abilities to reform a gay community that looks beyond sex acts. Prior's closing phrase "The Great Work" is recognized by Thomas Long as being "used by alchemists to signify the process of transmuting baser metals into the more perfect gold" (149). Long continues, "Transformation can be viewed as catastrophe or progress, or both, depending on the subject's perspective" (150). This idea of transformation speaks directly then to the ending of Millennium Approaches where the Angel seeks to transform Prior into a prophet (who in turn can transform humanity into nothingness), and carries through to Perestroika's epilogue where Prior calls for the gay community to transform itself. Prior's challenge gets to the heart of Angels in America's ending, and Long argues that Kushner's play asks "whether or not a society can be transmuted so that mercy and justice are conjoined" (151). I would extend this even further: Angels in America asks whether or not a homophobic society can cease its embrace of nostalgia and transform into a culture that promotes progress over punishment, and equality over separation. Kushner uses the AIDS epidemic to develop his own modified form of chrononormativity which allows the gay community to develop along similar, though distinct, lines as those promoted by the (often homophobic) hegemony. Prior's rejection of prophecy serves as an exemplar for the gay community - a paradigm through which they can reject the aspects of institutional chrononormativity that previously worked to omit or overlook the queer individuals of American culture. 
The ideologies of AIDS consisting of a series of conflicting ideas and representations, were generated from structures both within and apart from the gay community, and challenged prior ideological constructions of homosexual subjectivity and identity. Through their plays, Kramer and Kushner embraced these ideological differences and sought to offer resolutions that spoke to both the historic reality of the gay experience as well as the imaginary possibilities of progress and social change. Like Kramer before him, Kushner focused on developing a view of the gay community more as a bonded and united community than a collection of individuals working towards their own selfish ends. Since at its heart Angels in America is a fantasy, Kushner developed an ideology that must ignore its own origins - the play's fantasy of religion, angels, and prophecy cannot quite be believed by the audience all the while being developed and challenged by the characters within the play_ in order to create a space that can imagine a progressive queer future. Kushner advanced a form of community that went beyond sexual desire and activity and expanded the shared communal identity of the gay community, and by having the prophet Prior reject his prophetic constraints, Kushner offered a model for how the gay community can reject the hegemonic forces imposed on it. AIDS halted the social progress and change that developed in the decade following the Stonewall riots, but it did not stop it altogether. And though AIDS silenced many, it also gave voices to many more, each demanding to be treated as equal citizens with all the powers and protections promised. 
Chapter Three

"When No One Knew the Way Out":

Developing a Phenomenology of AIDS Through the Writings of Andrew Holleran

I have now lived half my life with AIDS, my constant companion and distant cousin, the inseparable identity I won't let define me, the everyday fact and special circumstance that bent the arc of my life in every way. (Trautwein)

Jan Grover, in a review of Andrew Holleran's Ground Zero, discusses the limitations of Holleran's collection of essays on the AIDS epidemic. "Because he cannot envision a collective response to AIDS, Holleran remains stranded in his own loss-impotent, because 'writing could not produce a cure"" Grover argues $(24,34)$. "Because he cannot arrive at an individual solution to It (the plague, the epidemic)," she continues, "he despairs, turns inward" (34, emphasis hers). It could be argued that Holleran's inward shift is no accident, but rather a critical reaction to the oppressive and opaque nature of an epidemic that clouds and distorts reality and understanding. Holleran cannot write an ideological solution to AIDS, no more than the medical establishment of the early and mid 1980's could create a medical solution to the virus, and so instead he remains both a part of, yet distinctly separate from, the gay community struggling in the midst of the plague. Throughout his essays and novels, Holleran's writing reflects the disorientating effect of the AIDS epidemic on the individual subject, in this case an HIV-negative man, and even turning inward does not offer clarity or relief. The analysis of ideological fantasies in Chapters One and Two was concerned with exploring the individual in the AIDS epidemic from the 
outside, more specifically how members of the gay community are a part of, and constituted by, a larger culture that critiques and condemns them as the public face of both homosexuality and AIDS. Here, I argue that a shift inward, addressing a phenomenology of AIDS, helps to flip this experience and examine what it feels like to live and to be lived in during the AIDS epidemic. While much has been said about feminist phenomenologies in the past few decades, including Sara Ahmed's groundbreaking Queer Phenomenology, little has been written about the phenomenology of AIDS from a philosophical, cultural theory point-of-view. This chapter seeks to identify a few of the important tenets of a queer phenomenology and build upon themarguing for the ways in which AIDS, both as a virus and an epidemic, challenges and expands our own prior understandings and analyses of phenomenology. Expanding on Edmund Husserl's extended metaphor of a writing table, Ahmed argues, "phenomenology makes 'orientation' central in the very argument that consciousness is always directed 'toward' an object" (2). Ahmed contends that phenomenology "emphasizes the importance of lived experience, the intentionality of consciousness, the significance of nearness or what is ready-to-hand, and the role of repeated and habitual actions in shaping bodies and worlds" (2). Extending from this, I argue in this chapter that a phenomenology of AIDS might examine how the epidemic disorients then reorients our individual perceptions - how AIDS both develops and ruptures identities and communities simultaneously. These struggles with dis- and then re-orientation are brought to life in Andrew Holleran's collection of essays about the AIDS epidemic in New York City, Ground Zero, as well as his novel about life in the AIDS epidemic, The Beauty of Men.

As phenomenology has shifted and grown, it has also made way for a form of "objectoriented ontology" (or OOO) that Ian Bogost argues "puts things at the center of being" (6, emphasis his). And while Bogost is interested in expanding the field of ontology to all things, not 
just humans, it is important to a queer critical analysis that the self-traditionally separated from the object—is as much a focus as, and on equal footing with, other objects in an OOO; "We humans are elements, but not the sole elements, of philosophical interest," Bogost argues (6). Bogost is actively trying to expand ontological studies to view every thing a thing worthy of study, including human beings, a move he recognizes as controversial. "Objections to OOO," according to Bogost, "often accuse it of seeing humans as lesser forms than other things, rather than as one of many units on equal footing" (131). This shift allows room for a new space of discourse to develop around a phenomenology of AIDS. I argue that AIDS also challenges what we consider objects as well as what we consider subjects — that is to say, do we allow/cause/see subjects with AIDS to become objects with AIDS? Framed internally, this phenomenological approach argues that since I can always "catch" it (the virus, the epidemic, or even the fear that accompanies it all), the possibility always exists and threatens my being as well as my becoming - that continuously fluid state which finds me always in the process of change rather than as a fixed identity. Through this, AIDS causes me to become an object to myself, and more crucially, causes me to no longer be transparent to myself. This occurs regardless of whether or not one actually has become HIV positive, since actually having the virus is irrelevant to its ability to distort, change, and threaten the self, both being and becoming.

A step back to explain further. Levi Bryant's OOO argues that "one object is simultaneously a part of another object and an independent object in its own right" (214, emphasis his). From this Bogost develops his own argument that "things are independent from their constituent parts while remaining dependent on them" (23). Moreover, these objects are constantly withdrawing from each other. In this chapter I argue for a different path forward; since Bogost is more concerned with alien objects outside of the body, I examine instead what 
happens when the thing withdraws from you, but the thing itself is you. So a phenomenology of AIDS argues not only that all things are apart from other things, but rather that AIDS makes one thing — the body/self —independent of itself; through AIDS, a part of the self is also an unknowable, alien object, much like the drawer might be unknowable/alien to the desk while remaining a constituent part of it. AIDS itself functions along a similar path: the virus itself is both an alien thing introduced into the body and a part of the self at the same time.

The literature of Holleran is an ideal venue for exploring these two related phenomenological effects of AIDS precisely because Holleran is so concerned with the gay body and how it is used to approach a gay identity and formulate gay culture/community. Holleran's first novel, Dancer From the Dance, was a 1970's exploration into and, as is often considered, judgment of the sexually adventurous gay community of the time. Holleran, like Kramer because of his novel Faggots, earned a certain level of notoriety for openly and sometimes judgmentally depicting the promiscuity of the decade. Following the publication of his second novel in the early 1980's, Holleran began writing a newspaper column about the AIDS epidemic in gay culture, eventually collected as Ground Zero (itself reprinted twenty years later, with some essays added as well some essays removed, under the new title Chronicle of a Plague, Revisited: AIDS and its Aftermath ${ }^{24}$ ). All the while, Holleran was starting and stopping his third novel, The Beauty of Men. Published and set in the mid 1990's, The Beauty of Men is about becoming a middle-aged gay man at a time when so many gay men were dying in their youth. What little primary plot there is involves Mr. Lark, who, having fled New York City during the height of the AIDS epidemic to north Florida to care for his dying mom, becomes obsessed with Becker, a

\footnotetext{
${ }^{24}$ For consistency's sake, quotations will come from Ground Zero whenever possible, and only those essays newly published/collected in Chronicle of a Plague, Revisited will be cited back to that text.
} 
brief hook-up Lark meets at a local cruising ground. AIDS is, in Holleran's writing, a singular force of nature that simultaneously destroys the gay body and restructures gay life/culture/community.

Reading through Holleran's texts with a critical eye reveals the need for a phenomenology of AIDS, one that moves beyond the initial stages of Ahmed's queer phenomenology by looking more closely at the interactions of bodies within the epidemic and how Holleran's writings both represent the trauma of those days and the challenges of moving the community forward in time and space. Laura Doyle considers how language can be used to focus on "the possibility of resistance" and focus on how language and the activism of bodies share a potential for challenging the structural ideologies that dominate a people. "To offer even contingent descriptions of the phenomena of bodies and the world they dynamically inhabit keeps in play an important, potentially oppositional field of action," Doyle argues (xii). For Holleran then, language is the tool of opposition, giving voice to a community struggling and dying within the AIDS epidemic while being virtually overlooked and ignored by a hegemony more interested in maintaining its own continued existence rather than the survival of the others in its midst. By invoking the bodies of the epidemic through language, Holleran creates an oppositional space for a counter-narrative, and a phenomenology of AIDS, more so than just a queer phenomenology, allows us to consider the plague as a fundamental component of the self—or what that body might become—rather than something that happened to it.

Holleran's examinations of the spaces and objects of the AIDS epidemic prefigure Bogost's phenomenological approach that gives us a terminology with which to analyze it. When Doyle discusses the objects of slavery, from hoe-handles to ripped shirts, she acknowledges the ways in which objects become a part of both their larger institutions and cultural movements of 
resistance. For Doyle, "Something in the durability, the shared palpability and visibility of objects, makes them susceptible to these dynamics of appropriation and counter-appropriation, or perhaps more accurately coappropriation" (xii, emphasis hers). This potential for coappropriation is what Holleran's texts promote and embrace by allowing us to see not only the bodies of the AIDS epidemic but also examine the spaces those bodies inhabit and the other objects with which they share those spaces. It is not so much that Holleran's writing becomes the object of a phenomenology of AIDS but rather that Holleran's coappropriation of the objects of AIDS means we need to construct a more specific phenomenological approach to get at the root of his literary and cultural considerations of the AIDS epidemic.

\section{DIS- AND RE-ORIENTATIONS OF AIDS}

There are, as might be expected, many ways to craft a phenomenological approach to the AIDS epidemic. By focusing on the individual bodies of the gay community touched by the epidemic, I can develop a clear structure for approaching a phenomenology of AIDS. Much of Holleran's writing throughout the late 1980s and early 1990s, particularly his essays, is concerned with understanding how the epidemic disorients but eventually reorients the gay self and its perceptions. By focusing on specific aspects of how gay life was then, Holleran's work emphasizes the ways in which AIDS developed and ruptured gay identities and communities simultaneously. The ways in which the gay subject interacts with cities, hospitals, art and language, and people with AIDS (PWAs) are all different yet connected aspects of the altered gay life that Holleran critically analyzed, as each interaction underwent distinct shifts throughout the AIDS epidemic — shifts that required the gay individual to constantly be re-orienting itself. 
Phenomenologically speaking, orientation has much to do with our notions of Space. How bodies are situated in Space speaks directly to the ability of that body to operate and function within that space. As Ahmed argues, "Space then becomes a question of 'turning,' of directions taken, which not only allow things to appear, but also enable us to find our way through the world by situating ourselves in relation to such things" (6). Ahmed uses Immanuel Kant's example of being blindfolded in a room to consider the function of a body in Space- how does a body know which way to turn, or where the walls or other objects are within that space, or, quite importantly to our own discussion here, which way is the way out. "Orientation involves aligning body and space," according to Ahmed. "We only know which way to turn once we know which way we are facing" (7, emphasis hers). The challenge comes from the not knowing, of figuring out how a body—presumably your own body—should move into alignment with the space around it. There is a shift through time that occurs too, as bodies move through Time and Space simultaneously, and attempt to (re)find a desired orientation/position in space. Ahmed postulates that bodies "come to 'have' certain orientations over time and that they come to be shaped by taking some directions rather than others and toward some objects rather than others" (58). How a body defines itself is a result of repeated actions, of constant movement in a space, and the reactions of that space to that body. In Ahmed's queer phenomenological approach, the body's actions also correlate to its inactions, emphasizing that a body's future options - its potential to orient itself-is heavily reliant on what actions a body never engaged in: "The field of possible action, of what this or that body does do, also defines a field of inaction, of actions that are possible but are not taken up, or even actions that are not possible because of what has been taken up" (58). All of this, of course, gives the body a certain degree of agency in a space - it is the body that orients itself, it is the body that chooses its actions. And though 
action and inaction may limit future choices as the body moves through a more metaphorical space of life choices, it is the body that must make its own way in/through Space. The AIDS epidemic, I argue, destroyed a certain degree of a body's agency when it came to both physical and metaphorical space - the virus limiting future choices and forcing (re)orientations of the gay subject specifically (because of its already tenuous historical, social, and political situation within the world), regardless of whether or not that body actually contracted the virus.

How a body lives in and moves through Space is at the heart of Holleran's writing. In both his essays and novels, the New York City of the 1980s exists in a special, separate space, as a focal point of the gay community and nexus of gay life and culture. Moreover, the city itself is an integral piece of gay culture, its streets and buildings all contributing to the shared history of gay life. As Ahmed writes, "Familiarity is shaped by the 'feel' of space or by how spaces 'impress' upon bodies" (7). For Holleran, and for many within the gay community, with the onslaught of the AIDS epidemic New York City changed alongside the gay community. In his new introduction to the updated essay collection, Holleran invokes this when he describes his earlier writings: "by 1986, I was writing only two kinds of essay: descriptions of New York-as-acemetery and elegies for friends" (Chronicle 5). The city of the 1980s shared the funereal qualities of its gay community, until the city itself felt like one large cemetery or memento mori. Through his essays, Holleran could illustrate the disorienting, restrictive, and destructive nature of the AIDS epidemic: "Here are a vanished time and place: gay New York, when no one knew the way out" (Chronicle 14). The disorientation brought about by the epidemic went hand in hand with its reorientation - the city once full of life changed until it became little more than a symbol of death. "Much about New York seems small to me now, however-as if the whole city has shrunk to a single fact," Holleran writes (Ground 19). Holleran mirrors this in The Beauty of 
Men when Lark returns to New York City for a visit with old friends: "Once back home, however, merely walking the streets, he began to realize the city had turned into a vast cemetery" (153).

A brief aside: the city need not always be New York City, since essentially for Holleran all cities exist/operate/function only in their relation to AIDS. ${ }^{25}$ Holleran opens The Beauty of Men with an extended description of the local boat ramp where men in northern Florida regularly meet for sexual encounters. There is more than sex to the boat ramp, of course, as its titular function remains operational, but the men's room at the boat ramp seems eternally covered in sexual messages and graffiti. Holleran compares these drawings to "something in ancient Pompeii: obscene and lurid" (Beauty 1), but goes without stating the other obvious parallel: both the men's room at a Florida boat ramp and the ruins of old Pompeii function as remnants of destroyed culture laid to waste by a natural catastrophe of epic proportions. Whether living in Florida, New York, or elsewhere in America for that matter, AIDS was the gay man's Vesuvius, and the drawings on the men's room walls are, particularly in the eyes of the relocated Lark, the displays of a culture, relocated and stripped of their space and permanence.

A phenomenological approach allows for a theoretical conception of Space in ways that inform the history of AIDS in America, specifically as historicized by Holleran's writings, which in turn provides the framework for a phenomenology of AIDS that goes beyond spatial dimensions. Within Holleran's essays, New York City is an object unto itself: a collective singular object, full of individual discrete components that make up the whole. Holleran understands, that is to say grasps the quality of, the city through his physical movements within

${ }^{25}$ And, of course, throughout the 1980's and 90's there was a population of more than 7 million people for whom New York City was not simply a cemetery. 
the city. As Ahmed argues, "We perceive the object as an object, as something that 'has' integrity, and is 'in' space, only by haunting that very space; that is, by co-inhabiting space such that the boundary between the co-inhabitants does not hold" (54). Ahmed is speaking specifically about the touching of skin to surface, and though she does not explicitly state it, about the way the grooves of the skin overlap and connect with—blending into - the very object being touched. In the essay "Circles," when Holleran learns that Cosmo, an old friend he had not been in contact with in years, had suddenly died, Holleran attempts to use a walk through New York City as a means to re-orient himself:

Downstairs the weather had changed; after a warm couple of April weeks—Cosmo had died in September - it was nippy again, like a fall night. The World Trade Towers twinkled in the blue dust. The crowds surged down Saint Marks Place.... Yet a small part, an individual cell, of Manhattan had been extinguished. Out of the huge honeycomb of the city I walked through, one chamber was empty. (Ground 61-62)

Within Ground Zero, the city is both a place and an object, and as a body moves through it, the city changes and shifts as well. Ahmed calls this to mind when she writes, "phenomenology reminds us that spaces are not exterior to bodies; instead, spaces are like a second skin that unfolds in the folds of the body" (9). Moreover, the way places in the city shift their meaningfrom who was once there to the memories of them-Holleran calls these "holes in the landscape" that he is constantly "running into" as he goes about the city (Chronicle 231). The remembrance brought about by AIDS is distinct from nostalgia; when a friend says to him, "We had the best times. The best times," Holleran explains,

Everyone feels that way about his youth, no doubt—but this time it's not just nostalgia. People and places have disappeared. The city is shrinking. New York is strangely 
haunted. ... Everyone engineers the particular mix of past, present, and future he wants in life — by staying, or moving away; changing, or keeping, a job; acquiring, or losing, friends - but this time the city has silted up with the Past. (233, emphasis his) When it comes to the AIDS epidemic, the city goes part and parcel with the gay community that resides within it. It is not just people who haunt New York, the city also haunts itself as its lost or forgotten spaces function as ghosts of a time passed, and for Holleran, these lost spaces might be gay bars, cruising grounds, or bathhouses. As David Caron wrote, when contemplating Holleran's notion of Ground Zero, "If urban space is shared space, we must share it also with the missing" (Nearness 68).

More than just the remnants of the lost or gone, the city also shares the health status of its inhabitants. Holleran elaborates on this in his essay "Ties" when he considers all the changes New York City has undergone during his comings and goings in the early 1980s. "When you leave New York and come back, the joke is you find nothing has changed - despite the infinite number of trivial events - but this time I learned a lot had," Holleran writes (Ground 202). His examples were of the usual life-event kind, where the subject is in a constant state of becoming. Friends had moved or changed careers, as one might expect, but also so many of them were depressed, and more importantly, the sick remained so; the sickness, in a sense, arresting the natural progress of the self-becoming. And it is not only the people who are considered sick; the epidemic infects the gay community as well as New York: "One arrives and expects to see progress ... your city cured of the plague. But apparently there is no cure for this plague" (202203). For its gay population, the New York City of the 1980s was just as disoriented by the AIDS epidemic as the gay community that dwelled within it; for its gay inhabitants, the city also 
reoriented itself around this new normal of sickness, changing, shrinking, disappearing, and yet reappearing with new centers of focus and relevance.

The city's individual components also have a disorienting effect because of the AIDS epidemic. Places like hospitals and cemeteries that once seemed innocuous or left in the background of daily life take on new, harsher meaning as they become shifted more and more into focus. As Holleran writes in "Bedside Manners," "The world has a surreal quality to it when you are on the way to the hospital to visit someone you care for who is seriously ill: Everyone in it, walking down the sidewalk, driving by in cars, rushing about on a basketball court with sweatstained chests, exhausted faces, and wide eyes, seems to you extremely peculiar. They are peculiar because they are free" (Ground 37). The effect occurs regardless of whether the person heading to the hospital is sick or well — the virus has infected, and therefore disoriented, the entire gay community, and called it out apart from the mainstream culture going about its regular business.

Sickness is disorienting; it introduces us to what Holleran calls "the foyer of death"- the hospital room where we visit the dying that serves as "an odd place between life and death" created by modern medicine (Ground 41). But the hospital room also allows for a refocusing through a reorientation of sorts. As Holleran writes in "The Room," "Yet it's strangely peaceful here; far more peaceful, in a way, than any other place in the city. The plague is not some dreaded amalgam of guilt and superstition that deforms our lives with anxiety and worry, some hidden assassin; it's here, out in the open, in this room" (Chronicle 51). If walking to the hospital is disorienting, due to the inequality of health statuses, then the room-containing the HIV positive body - is itself a vessel for reorientation. It is not that the visitor takes the position of the outside culture going about its business; after all, the visitor, though not in the bed, may still be 
carrying the virus and/or is still feeling the effects of the epidemic in a visceral way. Instead that being, already disoriented by the epidemic, can use the hospital room as a means of establishing realignment. Robert Miller analyzes a case study where this very idea is attempted. Miller follows Larry, a 51-year-old African American man diagnosed with end-stage AIDS. Larry, faced with a fatal prognosis, "believed he could initiate and experience an encounter with God that would save his life" (Miller 41). Miller recounts how Larry "transformed a hospital room to a prepared place to be touched by God" (35) through several spiritual steps (including a prayer of appointment, a call to God, and a testimony). In this rather specific case, the being infected with AIDS and thereby disoriented uses the space of the hospital room to reorient himself, shifting his focus from the medical to the religious.

Holleran attempts to extend the ways an understanding of AIDS reorients within the context of the culture's interactions with the medical establishment. Consider the medical reorientation of the prophylactic, as Holleran does in "My Little Trojan," bought "not to prevent pregnancy (the reason the Catholic Church forbids them), [but rather] to prevent death" (Chronicle 156). The condom takes on symbolic components in its new orientation: "He intends to carry one at all times, like a Boy Scout with his Boy Scout knife. He is now safe. The rubber in his pants pocket is like a crucifix in a land of vampires" (157). But the condom cannot escape the connotation of death—even Holleran's symbol of the crucifix is itself a symbol of death-the presence of AIDS figuratively killing the mood as it were: "In the midst of pleasure, the rubber recalls disease, danger, death, his own friends' illness. Its use is prudent, rational, sensible. But sex is a surrender to what is not prudent, rational, sensible. It is the escape from these" (158). And so even the condom becomes a critical focus in considering the disorienting effects of AIDS; when the object itself comes into contact with the body it becomes a physical 
representation of the virus - its history, its positioning within the community, its prevention, and even its future possibilities.

In a phenomenological sense, disorientation is not limited to the AIDS epidemic; its presence - and its effects - is a universal experience of life. As Ahmed argues:

The point is not whether we experience disorientation (for we will, and we do), but how such experiences can impact on the orientation of bodies and spaces, which is after all about how the things are 'directed' and how they are shaped by the lines they follow. The point is what we do with such moments of disorientation, as well as what such moments can do - whether they can offer us the hope of new directions, and whether new directions are reason enough for hope. (158)

What AIDS does differently, however, is reshape the world around it. It is not simply a matter of reorienting oneself in the same space after becoming disoriented; AIDS reshapes the space itself and leaves only new directions, many of which seem hopeless. Holleran tackles this hopeless disorientation in his essay "Reading and Writing" as he is forced to reconsider the position of literature in the age of AIDS: "Literature could not heal or explain this catastrophe; the one thing about the plague that became clearer as it progressed was its senseless, accidental, capricious quality" (Ground 16). And in some ways, these changes seem hopeless when it comes to writing about the epidemic. Since everyone is interacting with the epidemic, on an individual basis, and reorienting themselves accordingly, Holleran recognizes that the current struggles of writing about AIDS will continue on, whether or not the epidemic does: "Someday—not just yet—there will be novels about all of this, but they will face the problem writing about it stumbles against now: how to include the individual stories, the astonishingly various ways in which people have behaved" (27). These stories function as attempts to not only reorient one's life during and 
because of the AIDS epidemic, but also to loudly proclaim the realities of what it means to live in the time of plague. Michael Denneny, analyzing trauma writings (Holleran's Ground Zero in particular), argues, "All such writing has as its innermost principle the act of bearing witness. To bear witness is to declare oneself, to declare oneself present, to declare oneself in the presence of what has come to be" (48). Bearing witness and even outing oneself as a member of the community affected by the epidemic is itself a means of reorientation in the wake of AIDS. For Denneny, bearing witness brings the subject into direct communion with others, and operates in a separate space. "Those who bear witness carry the soul of the community," Denneny argues, "the stories of what it has done and what it has suffered, and open the possibility of its existence in memory through time and beyond death" (48). For those within the AIDS epidemic then, bearing witness through stories offers a specific form of reorientation focused on generating future memory and preserving the experience of the subject beyond death, particularly when the lifespan of that individual is cut drastically short by the plague.

At its core, developing a phenomenology of AIDS means understanding how the early stages of the epidemic lead to a reorientation of assimilation and association. Culturally speaking, AIDS effected a change in how the mainstream community talked about and addressed the gay community—a change that did not happen instantaneously, nor really ever ended. "There has been an extraordinary assimilation, and it's freaky when you are someone who remembers it was not always that way," Holleran argues. "AIDS accelerated this opening up. I think it was a means of making people aware of gay life, gay politics, gay art" (qtd. in Goldstein, Bill 42). This is not an apology for AIDS, but rather Holleran is offering a perspective on the epidemic that recognizes how it reoriented not just the gay community inside of itself, but also within the larger world. This reorientation also carries through into how the language used by the gay 
community has shifted because of the epidemic. In "Notes on Promiscuity" and "Notes on Celibacy," each structured as numbered lists, Holleran considers how the AIDS epidemic has broken down what terms like "promiscuity" and "celibacy" meant and restructured them into something different. "Promiscuity" ends with a reorientation of association:

93. Promiscuity was once associated with joy, travel, toothpaste, Brazil, San Juan, Paris, Berlin, hamburgers, automobiles, insurance, poppers, gymnasiums, designer jeans, designer drugs, Calvin Klein underwear, discotheques, cosmetics, vitamins, clothes, movies, airplanes, subways, men's rooms, piers, Central Park, Land's End, Buena Vista Park, Folsom Street, the West Side Highway, marijuana, cocaine, ethyl chloride, Mexico, the Philippines, Miami, Provincetown, Fire Island, Canal Jeans, Bloomingdale's, the balcony of the Saint, bars, baths, sidewalks, Lisbon, Madrid, Mykonos, certain magazines, four a.m., Stuyvesant Park, the grocery store, the laundromat, autumn, summer, winter, spring, bicycles, T-shirts, and Rice-A-Roni.

94. Not anymore. (Ground 119-120)

With "not anymore," Holleran is in no small way mourning the loss of the gay culture and community fallen to the AIDS epidemic, while recognizing that those things that once seemed so free and open (he begins with "joy" after all) have, by 1988, been collapsed and reduced to the simple equation sex=death, and in "not anymore," Holleran, as so many others have, elides the slide from promiscuity to sex. As Holleran would later write, "It remains sex-and we remain its prisoners, who find it hard to remember that sex was once life, not death. But it was" (Ground 174). He elaborates on this reorientation/re-association further: "Such moments are gone now, but in mulling over good and bad sex, it is interesting I think that I hardly remember the sex itself... What I remember is the feeling of being alive" (174). 
Holleran pairs this recognition of reorientation with a consideration of a gay subject's new relationship to celibacy in the next essay. After discussing the history of celibacy, and its cultural references/connections to the Catholic Church, Holleran outlines the shift in celibacy, for those who are not Catholic priests, as it were:

8. There are only two reasons to be celibate: so you will not infect yourself; so you will not infect others.

9. For example, a friend of mine who became celibate four years ago to preserve his own health, a man whose diet, exercise regime, personal life has all been geared toward physical well-being during the oh-so-health-conscious seventies, contracted AIDS last winter and died, astonishing all his friends. Moral? He perhaps prolonged his own life by not reexposing himself to the virus, but, best of all, and here was his greatness, he infected no one else. (Ground 122, emphasis his)

And while Holleran spends much of the essay working through its complexities, celibacy, having encountered the AIDS epidemic, remains the polar opposite of promiscuity in that it, unlike the manner in which promiscuity has been reduced, has seen its potential signification explode with possibilities. Ultimately, despite wondering how AIDS has already changed, and will continue to do so, the gay community's association with celibacy, Holleran concludes that " 67 . Celibacy is the future" (129).

Along the same lines that disorientation occurs to everyone in some form or another, Ahmed also argues that to be disoriented is not, inherently, a negative action or result, but rather a changing or restructuring of potential options for moving forward. "Disorientation, then, would not be a politics of the will but an effect of how we do politics, which in turn is shaped by the prior matter of simply how we live," Ahmed argues (177). And so while living certainly has a 
great effect on how we are disoriented (and what options we are presented with for reorientation afterwards), it is not itself a moral judgment on how we live. Instead, disorientationexperienced differently by everyone — offers everyone a separate opportunity for how they find realignment. Ahmed writes that life experiences have an effect on what options are available for the subject seeking reorientation: "what we 'do do' opens up and expands some capacities, as an 'expansion' in certain directions that in turn might restrict what you can do in others" (60). Throughout the course of the AIDS epidemic the potential capacities for those struggling to survive changed; certain allowances and restrictions opened or closed depending on how sick one was or what medical possibilities were available at the time. The options for reorientation were not inherently restrictive, though AIDS certainly closed off many possibilities or made others seem hopeless or pointless. Holleran talks about the means of reorientation available to a PWA in the mid-80's in the essay "Emmanuel's Loft" (the title an ode to James Baldwin's queer classic Giovanni’s Room), when Emmanuel tells him, "I feel I am just maintaining myself, just trying not to die. It's very strange" (Chronicle 195). For other PWAs, they try to reorient themselves within both the gay community, but also the community of other PWAs. Holleran relates a story about a couple he knows who both tested positive together: even though both men seemingly have the same potential options available, they are making very different choices in how they reorient themselves. While one is working through it, the other is shutting down; it is not their medical conditions but rather their emotional and social means of reacting to and processing the virus that is driving them apart. "So he's going out that evening, he says, to a party being given for men who have tested Positive, to meet someone who will give him the support he needs," Holleran writes (220). 
Not everyone with AIDS behaves similarly, of course; the group is no more monolithic than the overall gay community is, despite a cultural perception otherwise. Consider one of Holleran's observations of the differences between those who are positive and negative: "The paradox of the plague has been how gallant, calm, brave, witty certain people with AIDS seem, in contrast to those who only fear they'll get it" (Ground 227). "Certain" is, of course, the key word here —not all PWAs are gallant, calm, brave, or witty and many attempt to reorient themselves by using the virus to garner as much attention as possible. In "Sheridan Square" Holleran's discussion of Jeff, his friend with AIDS, focuses on the power of AIDS to disrupt when they dine out at Spaghetteria: "If you want to be seated very quickly, take a Person With AIDS to dinner" (Chronicle 90). Jeff With AIDS is a prima donna, something Holleran seems to present as a change from Jeff Before AIDS, and as a result, dining out with a PWA becomes "a scene. It's theatrical. It's sad" (90). During dinner Jeff "put the hood on" his hooded sweatshirt "and ordered the waiter to turn down the air-conditioning because he had AIDS. Incredibly, in a restaurant filled with other people, the waiter complied" (91).

Sex acts are another set of potential behaviors that have altered as a result of the disorientation caused by the AIDS epidemic. And this disruption — this loss of focus and stability — is not limited to those with the virus, but rather it affects the entire gay community and the social structures around which that community had been organized. In The Beauty of Men, Lark considers the challenges of bathhouse sex in the age of HIV: "Which is the better reason not to have sex, he wants to ask the attendant ... HIV or meaninglessness? Maybe HIV provides meaning — that's what Roy said when he got it, at any rate: "Now my life has some structure"” (219). The revelation, of course, is not that Roy's life before the virus actually lacked structure, but that HIV restructured and refocused his life into a completely new thing - the virus 
reoriented life and sex in a meaningful way for everyone. Lark recognizes this himself later as he contemplates casual sex at the bathhouse. "Having sex with these men here would be like spitting on his friends' graves," Lark thinks as he watches men going off to have sex all around him. "Too many have died, too many have suffered, for sex to be casual again or what it used to be" (224).

The struggle to understand what AIDS changed is a central focus of Holleran's writing, with even Holleran attempting over the course of two decades to figure it out. On one side is Holleran's plea that things have to change - that the gay community must not go back to their behaviors from before the plague; but Holleran contrasts this with the reality that, probably, nothing will really ever change as gay men will most likely continue to have as much sex as they want. Lark struggles with these conflicting future options in The Beauty of Men: "The virus made us all third world. And changed absolutely nothing otherwise. Even though the moment it began, everyone thought, Everything will change now. Change utterly" (224). But Lark is partially wrong-AIDS did change things for the individual subjects of the gay community. It disoriented the entire gay community, and the hetero- community's relation to it, but the epidemic did not stop there. It also re-oriented gay life, sexuality, and culture, and the virus became an inescapable and inseparable component of gay sex, regardless of whether or not the individual's choice was abstinence or promiscuity. "AIDS," Holleran writes, "made people ask: What are we to one another?" (Chronicle 10). And rather than completely destroy gay culture, it gave the gay community a pause to (re)consider those potential options for reorientation. The AIDS epidemic highlighted the tentativeness of the being and re-inscribed the presence and process of becoming, the gay subject and community both in a constant progression forward in time. The virus disrupted the culture but did not collapse it, and so while things changed, the central focus points 
of living remained: "Times had changed, and changed radically, but each one of us is still trying to find the same old things: sex, and love, and self-respect" (Ground 178).

One of the reasons for the difficulty in understanding the changes brought about by the AIDS epidemic comes from the then limited means for testing for the virus as well the overall potentially long dormancy of the virus within the body, two components that separated the moments of contraction from the period of revelation, often by months or years. As result, AIDS was located simultaneously in the past and the present - creating an extended period of temporal disorientation, more often than not filled with similar behaviors to those from before the instance of infection. The idea that AIDS is simultaneously located in the past is also invoked in the essay that gives the book its title, "Ground Zero" where Holleran uses an extended metaphor of AIDS as a bomb dropped on the gay community, more specifically in New York City, and the (false) idea that some escaped the bomb by leaving the city before '83: "The bomb fell without anyone's knowing the bomb had fallen, which is how it destroyed a community that now seems - looking back — as extinct as the Mayans" (22). The simultaneous positioning of AIDS in past and present disrupts the natural processes of healing, grieving, and recovering, making reorientation that much more difficult. As Holleran writes, "So much for remembrance. So much for trying to draw a line between the past and the present. There is no clear boundary between the two" (49-50).

A phenomenological approach to the AIDS epidemic allows us to reexamine the potential options for a future and construct alternatives for reorienting the gay subject moving forward through time. Is it possible for a person, whether or not they contract the virus, to survive the plague? Looking forward from the confusing and disorienting 80 s and 90 s, the gay community was left wondering if there really was a potential future that is post-AIDS, or is every attempt at 
reorientation an extension of the self as reconstructed through the AIDS epidemic? Writing to a friend, Holleran discusses whether or not the members of the gay community can survive the plague: "No one who has survived thinks he has survived. That is, most gay men who've lost friends have no explanation, do not think this thing is over, still don't know what's going on, and are superstitious enough to believe that the moment they think they're a survivor, they'll get sick" (Chronicle 223). The epidemic looms over the community, shadowing future options not just on an individual level but on a cultural level as well. AIDS brought the gay community out of the closet for good, and shifted the cultural, political, and economic futures of the entire culture while simultaneously slaughtering its participants. As Holleran wrote, "Coverage of AIDS outed gay people and gay life - normalized them, at a terrible price: AIDS simultaneously destroyed that world as it was being revealed" (9). For Holleran, the destructive nature of AIDS sets it apart from other more seemingly ordinary methods of disorientation, while the simultaneous positioning of the epidemic in both the past and present disrupts future options for reorientation (though still allowing for some movement forward), as well as disrupting and disfiguring the very identities of the gay community and its members.

Yet from an objective position, apart from the epidemic that perhaps does not view things merely from Holleran's general insistence on AIDS being a matter of good versus bad, there are less negative outcomes to the reorientation of the gay community. Throughout the course of the epidemic, and certainly in its opening years when the scientific community was riddled with uncertainties, sexual behaviors changed and adapted — reoriented to accommodate the plague, as it were - and activities beyond at-risk penetrative sex were eroticized. In How to Have Sex in an Epidemic, Berkowitz and Callen notably included several creative forms of mutual masturbation, including group play, voyeuristic behaviors, shared showering, and even "creative penetration" 
options that embraced the use of dildos and other toys (23-25). These behaviors became sexier simply by being safer than the traditional penetrative forms of sexual activity that the gay community had oriented itself around for so long. AIDS had still radically altered, and for Holleran especially, disoriented, and disfigured the gay community and its struggling members. As the gay subject sought for the means of realignment, it also struggled with understanding itself and a whole new area of disorientation emerged as the gay subject looked inward. A crucial area of disorientation developed out of the erasure of subject and object as the AIDS epidemic revealed the self to be an object to itself. Since this disorientation exists beyond the more spatially oriented phenomenology developed by Ahmed, it becomes necessary to complicate a phenomenology of AIDS by taking a more object-oriented approach to the epidemic. The gay body living in the time of the AIDS plague-whether infected or not—disturbed the boundaries of subjectivity and became disoriented by the unknowable presence of the virus within itself.

\section{THE SELF AS UNKNOWABLE OBJECT}

Reading through Holleran's writing another phenomenological approach to understanding how AIDS impacted the gay subject becomes clear. The capricious and indifferent nature of the AIDS epidemic revealed how subjects with AIDS could be understood as objects with AIDS, and since a being might become infected by the virus, the epidemic, or the fear of both, the possibility continually threatens the gay subject. AIDS causes a subject to become an object to itself, and more crucially, causes a loss of transparency that renders the self foreign. Through AIDS, a part of the self is also an unknowable, alien object, while the virus is simultaneously both an alien thing introduced into the body and a part of the self. The fear of the unknowable, as I will explore shortly in this chapter, is a primary factor specifically in the AIDS 
epidemic, as, unlike previous plagues, the infected body need not bear the physical marks of the virus, or might remain unmarked for an extended (multi-year) period of time.

The relationship between subject and object—more specifically, the view that reads subject as equal to object—has been a long considered area of contention and analysis within phenomenology. Levi Bryant's approach to OOO analyzes how making distinctions between subjects and objects has influenced our way of thinking, as well as our ability to understand the world and ourselves. "Within the schema of representation, object is treated as a pole opposed to subject," Bryant argues. "Because the representation lies in the intersection between the two domains, there's a deep ambiguity as to whether or not representation actually hooks on to the world as it really is" (14). The confusion of understanding the self's relationship to objects comes from the system used to differentiate the two; so long as objects are continuously represented as apart from the subject, we struggle with how much of our understanding of an object comes from the object itself rather than from our own interactions with that object. Can the subject ever grasp the object as it is, or does it only ever understand the object as it relates to it? Bryant explains further: "As a consequence of the two-world schema [subject/culture apart from object/nature], the question of the object, of what substances are, is subtly transformed into the question of how and whether we know objects" (16, emphasis his). And it is the question of knowing that frames this phenomenological approach to the AIDS epidemic. If we cannot know the virus, or can only know it through limited means/representations, and the virus is a part of - $\mathrm{a}$ smaller piece of the larger whole—ourselves, then can we ever know ourselves? For Bryant, like Bogost, the self is just another object that holds no place of prominence or position of power over other objects. This is Bryant's democracy of objects (19) and what Bogost means when he says, "all things equally exist, yet they do not exist equally" (11, emphasis his). 
Bogost's work uses foundational phenomenologists as a launching platform for a new approach to the theory. "Being," Bogost argues in summary of the old ways, "exists only for subjects" (3). Moving swiftly through the works of G.W.F. Hegel, Martin Heidegger, Jacques Derrida, and Quentin Meillassoux (to name a few), Bogost condenses the correlationist approach to phenomenology into one simple claim: "If things exist, they do so only for us (4, emphasis his). It is here that Bogost makes his significant pivot into a post-phenomenological approach as he argues, "to proceed as a philosopher today demands the rejection of correlationism" (5). Moreover, Bogost and Bryant's approaches are a marked difference from Ahmed's, as she argues, "disorientation involves becoming an object," which is to say that the body that cannot recover from its own disorientation collapses and transitions into an object (159). For Bryant and Bogost, however, the subject is just another object, regardless of its (dis)orientation. By accessing the complimentary views of both Ahmed and Bogost, rather than rejecting or dismissing one for the other, I can explore more thoroughly how through AIDS (the epidemic as well as the virus itself) a part of the self/object becomes an unknowable, distinct subject/object that is constantly withdrawing from the other/self. The viral nature of HIV/AIDS contributes in no small part to the seeming unknowability of the virus inside the body. Alexander Galloway and Eugene Thacker critically approach viruses, both biological and computer versions, as cryptographic forms, "predicated on mutation and morphology, on recombining and recalculating as a way of never-being-the-same. ... What astounds [them] is that the viral perspective presents the animal being and creaturely life in an illegible and incalculable manner"

${ }^{26}$ There are also hints and echoes of the works of Gilles Deleuze and Félix Guattari, though Bogost does not make them explicit, in particular their analysis of multiplicity, which was "created precisely in order to escape the abstract opposition between the multiple and the one" (32). 
(87, emphasis theirs). It is not enough that the virus itself mutates so as to never-be-the-same, it also distorts the being it inhabits so as to make that life illegible. ${ }^{27}$

The presence of AIDS in the body challenges the ability of a subject to see itself only as a subject. Rather, the self becomes an object, comprised of many objects, one of which includes HIV. As Bryant argues, "Objects can enter into exo-relations with one another, but they are not constituted by their relations. ... the subsets of a set, the smaller objects composing larger objects, are simultaneously necessary conditions for that larger object while being independent of that object" (214). If one were to balk at the suggestion that the virus is a "necessary condition" for the gay male body, consider instead that it is a necessary condition for that body to be considered a positive gay male body, which, while independent of the virus, contradictorily cannot be composed without it. Caron attempts to come close to this idea when he analyzes the shifts in perspective for the HIV-positive person. "This HIV-negative, healthy body that was once yours is still somehow with you or near you but no longer you, not really," he writes. "In fact, not unlike a younger age, it appears sometimes as if it were incarnated by others" (Caron, Nearness 111). Despite feeling like you are not yourself, Caron ultimately gets around to the idea that although there is a disconnected space between who you were and who you think you are

${ }^{27}$ Zach Blas, in his article "Virus, Viral," begins the work of exploring how the virus itself might be conceived of as an object, playing off of both Bogost's approach to OOO and Jakob von Uexküll's theory of Umwelt, which allows us "to think about the radically diverse sensory worlds that different creatures exist within" (33). Ultimately Blas is left asking a lot of unanswered questions as jumping off points for a larger discourse: "can the idea of alien phenomenology be used to speculate upon the virus's Umwelt and, as a result, conceive a new viral? This viral would surely bring about a different viral, or unhuman, politics" (35). From this we could also develop further questions of ethics, including asking what the ethical responsibility of the host is to the virus itself. 
(the independent nature of AIDS leads to this as it infects the negative body while retaining its independent separation as an object), the reality is that the self is still the self regardless of whether or not one houses the virus. Holleran gets to this point when he critiques the behavior of a gay HIV-positive friend in The Beauty of Men. When Lark and Sutcliffe discuss the behaviors of Dutton, a mutual friend who has the virus, Sutcliffe will not let Dutton off the hook for his rudeness: "Don't blame the caviar on AIDS. Dutton did things like that long before the plague. AIDS doesn't change people, it just highlights certain aspects" (Beauty 158). Of course the virus changes people — it weakens them, sickens them, destroys them — but Holleran challenges whether or not the virus can change the personality of the self, that core of who someone is and how they behave within a community. Does the virus just bring out a less inhibited version of the self?

Within Holleran's plague experience, the HIV positive self is different precisely because one sees oneself as diseased and dying, rather than the "healthy" self that once existed, and therefore is allowed to behave without societal inhibitions, restrictions, or cultural niceties. A little more nuance, perhaps, can be developed outside of Holleran's texts. Consider how Ross Chambers discusses the writing of Pascal de Duve, and talks about de Duve's "understanding of AIDS the beloved, as both that which opens vast 'extraterrestrial continents' of experience and that which defines a living identity even as it destroys the sufferer" (160). De Duve's writing, Chambers argues, presents "clearly that the syndrome is not only, like love, a state of grace ... but also, because of the unique way it identifies living with dying, like rust eating a ship, a factor of identity" (161). The metaphor of rust brings the idea back to Bogost, for just as rust operates as a subset of the larger object, so AIDS, corroding the body it is a part of, consumes its own host, changing the foundational identity of the self as it goes. Similarly, Roberto Esposito's work 
on viruses and immunization looks at how AIDS affects "an entire ontological scheme: the identity of the individual as the form and content of its subjectivity" (162). "AIDS," Esposito argues, "ravages its subjectivity because the disease destroys the very idea of an identity-making border; the difference between self and other, internal and external, inside and outside. ... AIDS is the exact opposite of the immune system: not the internalization of the outside, but the externalization of the inside. It is the inside projected outside itself" (162).

For Holleran, the virus has infected the identity of an entire community, saddling it not only with the stigma of AIDS but also fully immersing the gay body in a culture marked and defined by the epidemic. And the gay body that tests HIV negative can be just as unknowable as the one that tests positive, both within and without the gay community. Mark Trautwein explains this connection: "As the epidemic grew through the 1980s, all gay men lived with AIDS, whether infected or not." In this way, the virus became a subset of every gay subject, regardless of infection status. Caron elaborates, "In the pandemic, to be HIV negative means to live near HIV, in contact with it and with the people who 'have' it, and, while we cannot deny that some people have HIV and some don't, discordance need not be perceived as incompatibility but as nearness" (Nearness 170, emphasis his). Different from the homophobic exterior view that reads all gay men as sick/immoral, this nearness within the community means that, sexually speaking, one has to consider that all potential partners could be infected. Within the gay community this shift effectively turns every member into a potential carrier of the virus. Tim Dean explores this when discussing the bareback sex parties that emerged in the late 1990s that operated under a form of the old military policy “Don't Ask, Don't Tell." For Dean, this nondisclosure of one's serostatus during sexual activity was/is a form of closeting, "as double-edged as any closet, since it confers a measure of protection through deniability while incarcerating in silence those it 
shelters" (Unlimited 7). Holleran explores this closeted ambiguity when he has Lark comfort himself for failing to achieve orgasm at the bath, justifying the lack of sexual satisfaction by blaming the uncertainty of the epidemic: "He often argues that, given what's out there, in all its mutating varieties, it's better not to have sex (AIDS's comfort to the sexually deprived)" (Beauty 233). The feeling of helplessness that was felt by so many who tested positive for the virus in the 1980's extended even to those who had not. Holleran, in one of his letters to his friend Robert Prager, discusses what a positive test result might mean. In context, Holleran seems to be acknowledging Prager's announcement of testing HIV positive, a declaration apparently made in the previous letter to Holleran. Holleran responds, in a letter dated 25 July 1985, "I am sure I will test positive too, but since: this does not say whether you will develop AIDS, and since all they tell you if you isL [sic] Sleep, Exercise, Good Nutrition, etc. what can one do with that knowledge?" It is not that Holleran is being defeatist, but rather he is speaking from a place of fear and distrust, where he cannot even rely on his own body and actions to keep himself safe from the epidemic.

Holleran writes an entire essay dedicated to the fear surrounding the AIDS epidemic, especially how the HIV negative body (re)acts to the presence of the virus within the gay community and the fear of exposure and contamination. In "The Fear," Holleran directly speaks to how the AIDS virus causes the gay subject to become unknowable to itself: "Your bodywhich you have tended, been proud of — is something you begin to view with suspicion, mistrust... Your body could be harboring It, even as you go about your business" (Chronicle 123). The uncertainty is a primary factor in the alienation of the self, and the body becomes representative of the virus regardless of whether or not the larger-than-self "It" has actually been contracted. This is, in no small part, due to the unknowable nature of HIV/AIDS in the 1980s, 
where it can take months or years to develop and become visible or symptomatic in the body. And so even if the subject starts to follow less-risky behaviors, the fear of contamination remains because the virus could already be a part of the body. ${ }^{28}$ Holleran addresses this in both his essays and The Beauty of Men by considering how gay men moved away from New York City or other gay-centric locales in favor of other places with less instances of infection. Writes Holleran, "The Fear is so strong it causes people to change cities, to rewrite their pasts in order to imagine they were doing less than everyone else; because the most unnerving thing about the plague is its location in the Past, the Time allotted to it" (Chronicle 122). Here is a connection back to an earlier thread of the chapter: if the first part of this chapter talks about space and the second about becoming-object, then this is where the two phenomena collide.

Lark's flight to northern Florida, mirroring Holleran's own real-life movements, is repeatedly linked to the absence of AIDS, or rather, the potential for a space untouched by the epidemic. In the novel's opening pages, Holleran writes, "Here there is no plague, thinks Lark. Save what from heaven is with the breezes blown/Through verdurous glooms and winding mossy ways. Most of the time" (14). Holleran has Lark referencing "Ode to a Nightingale" by John Keats, though the poet begins the thought with "But here there is no light." Just as Keats' forest filters out the light, so Lark hopes that the woods of northern Florida will filter out the threat of the epidemic. Yet really Lark sees the safety there as an illusion; "Caveat emptor is the rule," he thinks, regarding whether or not one can trust a partner to honestly disclose his HIV status (15). For Lark, the fear accompanying the epidemic is as much a part of his life in Florida as it was in New York: "Gainesville is probably as infected now, in the core gay community, as

\footnotetext{
${ }^{28}$ Of course this fear and uncertainty lead to an even deeper level of instability as the self recognizes the overarching ontological instability that develops out of the understanding that one's body can become othered from the self.
} 
New York - these people have buried a lot of friends" (Beauty 149). Yet the fear does not seem to have gripped many of the gays living in this rural community. When Lark asks Becker if he'd been tested, Becker "shrugged and said, "No. Why should I be?"' (149). By giving in to the fear, Lark's alienation from himself and the gay community is complete, and wholly independent from whether or not he actually has contracted the virus. While Holleran might be distinguishing Lark from his Florida compatriots, no such distinction is applied to the gay community in New York; rather Lark in The Beauty of Men seems to be the exemplar of the New York gay culture.

If knowing oneself is obscured through AIDS - a component of the body has become unknowable, alien, and fatal to the whole - then this lack of knowledge must become a way of life for those living in the time of plague. The gay self, not a fixed subject but rather one in the process of becoming, fearing the virus in others as well as himself, must also come to an acceptance, an understanding, that allows him to go on living. In "Friends at Evening," a 1986 short story featuring Mister Lark that serves as an ad hoc prologue to The Beauty of Men, Holleran addresses the subject rather comically, through Ned's cavalier attitude. As Ned and Mister Lark take a cab to their friend's funeral, the cab gets caught up in the traffic. While Ned wants to walk for another cab, Lark does not, because he feels that Julio, their driver, has a soul.

"Richard, they all have souls," said Ned. ... "The question is, do they have immune systems?"

Mister Lark spluttered.

"The question is do we," said Ned. "And the answer is no."

“Do you think you're infected?" said Mister Lark.

"I'm sure of it," said Ned.

"But you haven't taken the test!" 
“I don’t have to," said Ned. "If I'm not infected, no one is." (103-104, emphasis his) The test is, at this point, a medical possibility, though many in the gay community questioned its validity, particularly because of the uncertainty surrounding the time gaps between contraction and being able to test positive. Ned, like many in the gay community, simply accepted an uncertain fate; one way to conquer the unknowable nature of AIDS is to assume a positive status, and, arguably, behave accordingly. When asked to clarify whether or not he has the virus, Ned responds, "Not at the moment ... But I'm sure it's in me. along with the one thousand other things swimming in my blood. My sister says I was naïve. Not to be more careful, suspicious, mistrustful" (109 sic). Ned turns this around on Lark however, making the reverse assumption about his friend's status, “'You're safe,' said Ned. 'Because I think of you as not having sex"” (104, emphasis his). This is the other way of navigating the unknowable, when it comes to others the gay self must make conscious choices regarding their potential likelihood of infection and behave accordingly, though Ned does not conclude that he and Lark should have sex, only that Lark is "virgin" territory, like "Sicily before the Normans. America before the white man. Mexico before the Spanish" (104). The irony of course is that just as Lark is no virgin, neither were those places devoid of life/death before being invaded.

Holleran also presents the reverse of this particular phenomenological coin: if you cannot come to an understanding of the unknowable within yourself, then actually having the virus becomes irrelevant as either way the end result is an early death. Throughout The Beauty of Men, Lark relates the suicide of his friend and roommate Joshua: "It was the fear of AIDS. It was his failure to find the affection he craved" (9). Joshua is, for Lark, "a psychic casualty of the plague" (14), as the actual cause of death becomes irrelevant (much in the same way people who die of AIDS are actually killed by opportunistic infections), and Joshua becomes another victim of the 
plague. Later remembering Joshua, Lark tells his friend Sutcliffe, Joshua "saw no future in homosexuality ... He wasn't straight, and he didn't want to be gay anymore" (247). Holleran seems to argue that it is Joshua's isolation from the gay community—physically and emotionally — that pushed him to no longer cope with a life surrounded by the plague.

In order to convey the isolating nature of the AIDS epidemic, Holleran uses lists as a specific phenomenological approach throughout his writings. Lists are, in Bogost's estimation, "the simplest approach" to the theory of ontography, which "involves the revelation of object relationships without necessarily offering clarification or description of any kind" (38). A specialized form of the catalog, lists string together ideas and objects but leave out logical connections or specific relationships. "Lists," Bogost continues, "remind us that no matter how fluidly a system may operate, its members nevertheless remain utterly isolated, mutual aliens" (40). Bogost argues that instead of the "comfort and compatibility" suggested by other phenomenological approaches to becoming, an alien phenomenology assumes an opposite position: "disjunction instead of flow" (40). Holleran embraces this alien nature of disjunction and isolation as he discusses the changing nature of Joshua:

Each time Lark returned [to their NYC apartment], Joshua had less of a sense of humor. The man who had liked to walk around the apartment in sling-back pumps, Jockey shorts, and a towel turban wrapped around his head, imitating Bette Davis, Katherine Hepburn, Julie Andrews, and the entire cast of certain films by Satyajit Ray and Ingmar Bergman, was now to be found sitting in a Brooks Brothers ensemble of cords, vests, and striped shirt after work, eating, when Lark arrived, his macrobiotic dinner-a strand of seaweed suspended before his lips between two chopsticks. (154) 
The unknowable within Joshua also becomes the unknowable part of Joshua to others. Lark does not recognize his friend as the epidemic has stripped not only life but also selfhood and identity away from Joshua, and Holleran uses the two competing lists to illustrate the young man's changing nature.

Joshua is not the only character that gets Holleran's list treatment, and the author seemingly becomes self aware when he writes a long speech for Lark that functions as a list of lists in "Friends at Evening":

“Don't you make lists? Lists of people dead, lists of people living you worry about, lists of people you don't worry about, lists of people who would tell you if they got it, lists of people who wouldn't ... lists of people you'd tell if you got it, lists of people you wouldn't. Lists of people you'd care for if they got sick, lists of people you think would care for you, lists of places you'd like to be when you get it, lists of methods of suicide in case you do." (95, emphasis his)

The list(s) here convey Lark's connection with and also isolation from the gay community; they challenge his current general relationships — who would tell him, who would he tell—as well as his close and personal connections - who would care for whom. Moreover, Bogost would argue the list fulfills a specific purpose, and that by using it in a work of literature, the author "hones a virtue: the abandonment of anthropocentric narrative coherence in favor of worldly detail" (4142). Yet ultimately, the list, like Joshua, ends in suicide, recalling for us Bogost's declaration that no matter how organized a list is it really betrays a tragic isolation of objects from one another. When another list appears, on literally the next page of the story, it is in the context of Lark's dead friend's phone book: "Dan Rather. Lauren Bacall. Jeff Aquilon. Roy Cohn. Liz Smith. ... He used them when he was arranging the fashion show for muscular dystrophy. But he put them 
in his book" (Holleran, "Friends" 96). Ned asks about the other names in the book-the ones that are neither famous nor in the men's shared circle_-“'A lot of Spanish names,' said Mister Lark, 'of no particular importance'" (96). These lists focusing on isolation merely become another literary tool for reinforcing the unknowable and challenging aspects of the AIDS epidemic, severing the relationship of self with self as well as self with other.

When a part of an object is no longer transparent to the rest of that object, it takes on a mysterious allure in its unknowability. In his analysis of allure, Graham Harman notes that with allure we have "strife between an object and its own qualities, which seem to be severed from that object" (150). Graham separates an object from its qualities, with a move to argue that such a separation leads to distance. "If objects are what recede from us, qualities are simply defined as whatever does not recede, allowing us to bathe in them at every moment," Graham argues (150, emphasis his). The allure is the part of an object that does not recede from another object and which Harman goes on to equate with our concepts of metaphor; Bogost boils down Harman's approach: "we never understand the alien experience, we only ever reach for it metaphorically" (66). In a phenomenology of AIDS, then, the possibility of the virus becomes that aspect that does not recede as we come closer_-"we" can be both the self as object and other selves as objects - and it remains as a metaphorical quality we are left with and drawn toward. AIDS as metaphor is nothing new, just ask Sontag, but this approach allows us to understand that every aspect of our understandings of AIDS is metaphorical because the AIDS epidemic was, for so long, such an unknown alien subset of the larger self. In The Beauty of Men, Holleran complicates this by interrogating whether old age in the gay community is a metaphor for AIDS or if AIDS is the metaphor for old age. Ultimately AIDS and old age are both the alien experiences of the gay community-essentially unknowable until one has contracted it, and even 
then, there is a struggle to properly comprehend them. Holleran is very literal with this connection between the two, writing, "It was hard to distinguish sometimes between the psychological effects of the two - age and AIDS. Both tended to produce withdrawal" (Beauty 35). But he also used wordplay to craft a quiet connection between the two ideas, such as when Lark, at the gym, "looks out over the sea of bodies, he sees one thing and one thing only: Time. Slabs of Time" (48). The slabs of bodies remind us of the slabs in the morgue, and as Lark ages, both the young bodies at play and the dead bodies at rest are unknowable to him: "Even without AIDS their world would have come to an end ... their nightclubs would have filled up with another generation" (30). ${ }^{29}$ Holleran uses metaphor to aid in our understanding of the epidemic; we can only really grasp for the qualities of the virus that do not recede and Holleran's metaphor of the allure of time and old age stands in for those aspects of the plague that we struggle to understand.

Understanding the allure of AIDS and how those qualities function in our quests for identity and understanding means we can also consider the ethical relation of AIDS to the gay being and of beings to each other in the time of AIDS. Can AIDS - the virus, the force of nature - be ethical in its behaviors? As Bogost argues, "ethical codes are always ethics for us," by which he means human beings (73, emphasis his). But ethics addresses "why and how

${ }^{29}$ There are several other connections between old age and AIDS throughout the novel: a beautiful pun on dying, "There is something deeply depressing about dyeing, or painting, your hair" (Beauty 179); a consideration on death in America, "Malls, gymnasiums, nursing homesthe institutions of modern life, he thinks; the Culture of Death, the pope calls it, the late Pax Americana: quadriplegia, AIDS, and television" (50); and when thinking about his mother's old age, "Her horror is being alone. (Mine too, thinks Lark, though as a middle-aged queen, I'd better get used to it.)" (166). 
humans ought to behave in and toward the universe, but not about how other objects ought to behave in relation to it" (74). But if AIDS is a subset of the larger object, and that object is the self, we can broach an ethics of AIDS, not only of the virus, but also of the epidemic and the body that tests positive for it. As Bogost challenges, "An object enters an ethical relation when it attempts to reconcile the sensual qualities of another object vis-à-vis the former's withdrawn reality" (77-78). This is essentially what a phenomenology of AIDS does; it asks not if AIDS behaves ethically but rather if it is ethical to say we can ever get to the heart of what AIDS is, since we cannot really understand it but rather only approach, metaphorically, that aspect that does not recede. Within The Beauty of Men, Holleran questions the behavioral ethics of the subject, not the virus, during the epidemic. As Lark relates the stories of Ocala Joe, a sick gay man who frequents the boat ramp, he considers the similarities in Joe's behaviors before he contracted the virus to those of his old friend Joshua who died before getting it: "When he was well, he was a chatty queen who used to talk about nothing but the size of people's dicks, and lie. Like Joshua, he lied constantly" (Beauty 15). Lark's consideration of Ocala Joe's honesty is important because of the ethical considerations of sex acts in the midst of the epidemic, particularly when one knows one is sick even if the symptoms are not yet visible. "Though he told Lark he informs everyone he attracts that he has AIDS, given his past history, there is no way of knowing if he's telling the truth" Holleran writes (15). Gay men must maintain their ethical positions to one another in the time of plague, and arguing that the virus is immoral does not alleviate the ethical obligations of those who interact with and are impacted by it; moreover it is unethical to assert that the AIDS virus is moral or immoral, since we struggle with understanding what the virus is apart from its allure. 
There is an argument that the ethics and morality of viral transmission changed greatly following the advent of the AIDS cocktail, and even more so following the medical establishment's ability to render an HIV positive person's viral status as "undetectable." undetectable, that is to say, to be in the medical state-of-being in which an HIV-positive individual has an undetectable viral load within their bloodstream, has changed the way the gay community engages in sexual practices. David Duran considered the ramifications of a 2014 study that showed that undetectable individuals had a zero transmission rate in the first two years of the study and noted that many HIV-positive individuals were now treating an undetectable status as a negative one. Duran worried, however, about these changes: "What I hope will not happen is for HIV-positive people with undetectable viral loads to hide behind these results and live life as if they were HIV negative. Not being able to transmit the virus is the only thing the two types of individuals have in common." Another complication-though perhaps a positive one - came in the creation of the drug Truvada, which serves as a preventative treatment for individuals currently HIV negative. Several writers, including Tim Dean in his essay "Mediated Intimacies" and David Caron in his essay "Truvada Mon Amour," are participating in an ongoing debate over the ethical, political, and cultural responsibilities that surround Truvada and other PrEP drugs. What is important for Dean is how the drugs that help positive subjects become undetectable and negative subjects remain negative "perform a kind of deconstruction on the binary opposition that has organized gay erotic life for decades" (241). Holleran's ethical concern of honesty have also been mediated by the advent of these chemical prophylaxis treatments, as PrEP drugs could seemingly function as self-defense drugs for the HIV negative

${ }^{30}$ Tim Dean finds the terminology ironic: "From a Foucauldian perspective the category of 'undetectable' could not be more ironic, since it relies on surveillance at the biomolecular level by an entire apparatus of medical power" ("Mediated" 241). 
body against the possibility that the unknown body with which one engages in sexual activities might be infected. And this potential end to sexual serosorting is what Caron embraces in his essay on Truvada: "the real progress is that a guy who announces he takes Truvada does not need to ask his sexual partner for his HIV status." Moreover, Caron argues, these drugs offer a path forward - a specific ability for the individual living in the midst of the still ongoing AIDS epidemic to reorient himself in an ever-changing, uncertain, and potentially unknown community. "PrEP revives the idea of shared responsibility for the burden of HIV infection...," Caron writes, "taking meds - the same meds - on both sides of HIV infection brings about a kind of involvement with the disease that rests on a willingness to share" (emphasis his).

Yet even with the new scientific advancements that rendered the alien within the positive body undetectable, the gay subject could not return to the condition it occupied prior to the epidemic. While the conditions have changed from the time Holleran wrote, we cannot return to a pre-Holleran state that shores up the boundaries between the subject and object. That boundary has been revealed to be porous and conditional, and the ontological instability initiated by the epidemic cannot be undone by medical treatments. A part of the self remains unknown and so in this way we cannot consider ourselves to be post-Holleran either. More boldly put, the erasure of subject and object means that, despite what the activists and critics might wish for, we cannot return to a state apart from the epidemic and cannot become "post-AIDS." Not that this will not keep the community from trying, from burying its head in the sand and acting as though the epidemic that fractured and disoriented an entire community—and from there the rest of the world — never happened at all. 


\section{CONCLUDING THOUGHTS}

The AIDS epidemic disrupted the gay community - the individual lives, the collective goals - and the gay subjects that remained were forced to restructure their own lives and futures. It did not matter whether or not a being had contracted the virus; AIDS ruptured and disoriented anyone who came near it. But reorientation remains possible. The body stumbling through the darkened room can progress, if only by recognizing that while some avenues for building a future may have eliminated or narrowed, other possibilities remain or come into focus. Holleran stumbles through his own understanding of the AIDS-stricken New York City of the 1980s, struggling to progress, to find a future out from the epidemic. Yet the gay community, and to some extent Holleran himself, utilized tools for reorientation including assimilation and association, to construct potential avenues forward. Developing a phenomenology of AIDS allows us to talk about these possibilities in new terms - recognizing that the epidemic that destroyed lives touched the entire gay community and those who survived (with or without contracting the virus) still have a future. Moreover, this phenomenological approach allows us to reconsider the subject as object—a controversial philosophical point—by seeing how the virus operates as a subset of the larger object it is contained by and seemingly inseparable from. The virus, and the fear of the virus, causes the gay subject to no longer be transparent to itself. Because we cannot contain or understand the virus living amongst us, we become unknowable to ourselves. And while what is unknown has changed over the past thirty years as medical and technological advances gave us more information about the virus and the epidemic, there still remains a part of the condition - the unknown of infection, of transference, of detectability — that causes a part of the self to be obscured. That part of us that we can see recedes and the gay being must approach the virus that remains on a metaphoric level. And though the virus functions 
amorally, without regard for the rules or constraints of heteronormative society, the gay subject still maintains an ethical obligation to other gay subjects living in the time of AIDS. 


\begin{abstract}
Chapter Four
"If Anybody Notices, Nobody Cares":

The Trace of AIDS in David Levithan's Boy Meets Boy and Perry Moore's Hero
\end{abstract}

If you're not ashamed of the sex you're having, chances are you're not doing it right.

(Hanson 132)

In the 35+ years since the AIDS epidemic began, gay culture in America has shifted significantly. As leaders of the gay rights movement emphasized social inclusion, with focuses on persons of color, transgender rights, multiculturalism, and intersectionality all being expanded in the $1990 \mathrm{~s}$ and into the $21^{\text {st }}$ century, a public expansion of the queer umbrella has occurred. ${ }^{31}$ Politically, the assimilationist ${ }^{32}$ aspect of the gay rights movement in America shifted towards marriage equality, with an emphasis on heteronormalizing gays who get married and have children, and all of the social, economic, and medical issues that attend the act of family-

31 This cultural shift is visible in the literature of queer studies that have been published over the past two decades, including works by Robert Reid-Pharr, Jack Halberstam, and Lillian Faderman, to name a few.

32 Craig Rimmerman, in his examination of LGBT movements in America, elucidates the two positions competing for bringing about social and political change for the gay community. "Assimilationists typically embrace a rights-based perspective and work within the broader framework of liberal, pluralist democracy," Rimmerman argues, while "a second approach, the liberationist perspective, favors more radical, cultural change, change that is transformational in nature and that often arises from outside the political mainstream" (2). 
building. ${ }^{33}$ Yet several prominent queer theorists took up the mantle of the liberationist ideology, arguing for a reimagining of not only the gay community but also how gender, sexuality, and sexual activity function within the larger culture. Michael Warner and Lauren Berlant, amongst many other queer critics, spoke out repeatedly against the gay community's push towards heteronormativity. "Making a queer world," they argue, "has required the development of kinds of intimacy that bear no necessary relation to domestic space, to kinship, to the couple form, to property, or to the nation" (Publics 199). Warner specifically bemoaned the gay community's push towards marriage equality throughout the 90 s, wondering why more important and urgent topics, such as "HIV and health care, AIDS prevention, the repeal of sodomy laws, antigay violence, job discrimination, immigration, ... and the saturation of everyday life by heterosexual privilege" were not deemed as urgent as the right to marry (Trouble 84). For Warner, and others, the gay rights movement got bogged down in assimilationist practices that prevented significant cultural and political change in favor of small steps towards public visibility, acknowledgment, and acceptance. Such a point-of-view, however, downplays the significant progress in legal and medical issues that came alongside the marriage equality movement, if you choose to get married, including issues of hospital care/visitations, estate law/tax, and, though still quite complicated, adoption statutes. ${ }^{34}$ Overall, assimilationist approaches won the culture war, though academia maintains its lean toward a liberationist approach for gay rights.

${ }^{33}$ This approach has been advocated and critiqued in many prominent texts over the past twenty years, notably including Andrew Sullivan's Virtually Normal (1995) and David Halperin's How To Be Gay (2012).

${ }^{34}$ Several Supreme Court cases directly addressed gay rights in the $21^{\text {st }}$ century including Lawrence v. Texas (2003) which legalized sodomy, United States v. Windsor (2013) which overturned parts of the Defense of Marriage Act, and Obergefell v. Hodges (2015), which 
This is not to suggest that the work of assimilation and liberation only began after AIDS "ended," but rather that the political and social efforts being placed behind ending the epidemic gradually shifted and opened further once the AIDS cocktail, a medication of antiretroviral drugs that consisted of several pills taken in specific combinations at specific times each day, was stabilized. Moreover, a new generation of LGBT activists and artists arose, filling the void the epidemic had created, and promoting a broader approach to queer rights. In 2012, Daniel Tietz bemoaned the gay community's reduced interest in the AIDS epidemic, noting that "more than six in 10 " of current infections of HIV are appearing in men who engage in sexual activity with other men (or MSM) and that "from 2006 to 2009, CDC data show, HIV infections rose by an appalling 48 percent" among African American MSM ages 13-39. "Gay donors are still giving generously to causes they believe in. ... somehow AIDS has fallen off, or at least moved well down, the list of priorities," Tietz writes. Regardless of a cultural shift declaring the end of the epidemic, HIV/AIDS is still here. The medical and technological advancements made have allowed us to push the virus and the epidemic into the backgrounds of our minds and our culture.

Medical advancements in the field of HIV/AIDS research radically changed both the impact of the virus as well as perceptions of the epidemic in both the gay community and the larger culture. These advancements centered around three major areas of importance: testing, treatment, and prevention. AIDS.gov records how in the mid-1990s the first viral load test was approved; the introduction of viral load testing, while less publicized as a significant event, was

provided that the fundamental right to marry applied equally to same-sex couples. Several legal guides, including ones in 2016 by Elizabeth F. Schwartz and James Obergefell, and Frederick Hertz and Emily Doskow, have been published to help navigate the complicated new laws and regulations. Additionally, the prominent gay activist website Towleroad.com features a regular column by legal scholar Ari Ezra Waldman that analyzes LGBT legal concerns. 
monumental in its impact (“A Timeline”). James Gillett, in his detailed examination of the epidemic, writes, “A viral load test measures the amount of HIV in a person's blood... the term 'undetectable' was used to describe when the level of HIV in a person's blood was below the threshold of the test" (120). Within a few years, being "undetectable" became the new normal for people living with HIV. And by the mid 2000s, saliva-based testing made testing for the virus easier not only in America, but around the world ("A Timeline"). Advancements in the treatment also made living with the virus more manageable, as the drug cocktails of the 1990s, once consisting of as many as 60 pills per day, gave way in the mid 2000s to a single-pill solution ("A Timeline"). This single-pill treatment ended the traditional AIDS cocktail, and revolutionized care around the world. As concerns over the epidemic became more global in nature, large segments of the gay community simply moved on. As Gillett argues, "self empowerment and community development had diminished with the rise of the AIDS industry" (150). While these advancements helped those already testing positive for HIV, other more recent, preventative medications directly affected the HIV-negative population. In 2012, the "FDA approve[d] the use of Truvada ${ }^{\circledR}$ for pre-exposure prophylaxis (PrEP). Adults who do not have HIV, but who are at risk for infection, [could] now take this medication to reduce their risk of getting the virus through sexual activity" ("A Timeline"). Altogether, these advancements contributed to the ideology that there was an "End of AIDS," at least as a death sentence for gay men in America. HIV/AIDS, the virus and the epidemic, is not the same thing in 2017 that it was in 1987 or 1997. It has become a treatable condition that is no longer life-threatening, and with medication that makes it "undetectable," can have little to no noticeable impact on a person's health. The gay community has allowed the concerns of the AIDS epidemic to fall to the wayside because it is, especially for white gays in living in America and Europe, treatable and preventable 
And so the work of this chapter is to examine some of those $21^{\text {st }}$ century texts of gay literature that have ignored or overlooked the AIDS epidemic, in an effort to unpack and tease out the trace of AIDS they contain. Culturally, the heteronormative hegemony no longer immediately connects gay identity with AIDS, which is to say that when someone says "gay" it is not automatically/instinctively coupled to the epidemic, subconsciously or otherwise. This is due, not only to progress in medicine, but also to the assimilationist approach that decouples sex from gay identity. ${ }^{35}$ Yet even if it we could wipe out the virus, or its cultural connection to the gay community, the trace of the epidemic - its imprint of the lives and relationships of the gay community at both the individual and cultural levels - remains. Let me expand this by way of analogy; my work in this chapter builds off the theory of the African American presence in American literature developed by Toni Morrison in her extended essay Playing in the Dark: Just as the formation of the nation necessitated coded language and purposeful restriction to deal with the racial disingenuousness and moral frailty at its heart, so too did the literature, whose founding characteristics extend into the twentieth century, reproduce the necessity for codes and restriction. Through significant and understood omissions, startling contradictions, heavily nuanced conflicts, through the way writers peopled their work with the signs and bodies of this presence —one can see that a real or fabricated Africanist presence was crucial to their sense of Americanness. And it shows. (6) In a similar way, I argue that a "real or fabricated" presence of the AIDS epidemic is crucial to our overall understanding of modern American queerness, and of the gay community as a whole.

\footnotetext{
${ }^{35}$ However, AIDS is still essentially coupled to "Other" at a cultural level, which in America invokes gay, black, and/or foreign identities, something directly addressed in, for instance, Jean Comaroff's 2007 essay "Beyond Bare Life: AIDS, (Bio)Politics, and the Neoliberal Order."
} 
And, as Toni Morrison explains further, "Even, and especially, when American texts are not 'about' Africanist presences or characters or narrative or idiom, the shadow hovers in implication, in sign, in line of demarcation" (46-47). The Africanist's shadow, itself a strong metaphor for the black community in America, is so monumental, Morrison argues, that even when a text was written without explicit reference to them, their importance, through word and deed, cannot be ignored. This is, metaphorically speaking, the work I see here in regards to the gay community and AIDS.

Because of the extensive, and successful, medical advancements that reduced the threat of the AIDS epidemic, we allowed a form of cultural amnesia, a forgetting of the past, to guide our actions and our activism. Heather Love focuses on what cultural amnesia, in general, does and means to the gay community. Love argues, "Given the new opportunities available for some gays and lesbians, the temptation to forget—-to forget the outrages and humiliations of gay and lesbian history and to ignore the ongoing suffering of those not borne up by the rising tide of gay normalization - is stronger than ever" (10). Yet despite this progress, the shadow of the AIDS epidemic hovers over the queer literature that came after it, regardless of whether or not those works of literature attempted to ignore or move past them towards the assimilationist aim of heteronormalization. This act of forgetting is often linked to a cultural myth connecting the past with destruction; "In turning back toward this lost world, [Lot's wife] is lost: she becomes a monument to destruction, an emblem of eternal regret" (5). Unlike Lot's Wife and Kushner's Angels, the characters in novels like Boy Meets Boy by David Levithan and Perry Moore's Hero refuse to turn backward. Kirk Fuoss, in his essay on the politics of homosexuality in young adult fiction, argues: 
what a text means depends not only on what the text says, but also on what the text does not say. For example, when a picture book depicts only Caucasians in its illustrations, the absence of minorities in the worldview projected by the text necessarily figures as a component in that text's meaning. Similarly, when YA novels include as characters only heterosexuals, the absence of gays necessarily figures as a component in the meaning of these texts" (163).

This metaphor continues then, as the absence of the AIDS epidemic still functions within our understanding of gay texts. The world still contains minorities, non-heterosexuals, queer subjects, and the AIDS epidemic, and as such we cannot ignore the significance of their absences in such analyses. Such absences are particularly prescient considering the greater shift towards inclusionary theories and practices with the gay community in the past twenty years. Carla Freccero examines how the idea of the queer represents a sort of Derridean différance as queer "works to undo the binary between straight and gay, operating uncannily between but also elsewhere" (18, emphasis hers). More specifically, Freccero argues, queer becomes a form of trace that allows us to process sexuality within hegemonic structures. "Queer," Freccero writes, "is what is and is not there, what disaggregates the coherence of the norm from the very beginning and is ignored in the force to make sense out of the unintelligibilities of grammar and syntax. Like the trace, it is empirically irreducible but not phenomenal. The queer can thus be thought of as the trace in the field of sexuality" (18). It is no small irony, then, that AIDS, itself irreducible, has become the "what is and is not there" within the literature of the post-AIDS $21^{\text {st }}$ century gay community.

In the 1980s and 90s, it had been an all-too-common trope of the young-adult AIDS novel to feature the sick uncle or neighbor who, through his untimely demise, teaches the hero or 
heroine about the gay community, tolerance, and acceptance. More often than not, the AIDS epidemic was treated as an after-school special, and novels like My Brother Has AIDS (1994), Oasis (1996), and No Big Deal (1994) did little more than remind kids that being gay was a death sentence. ${ }^{36}$ While there have been several works of young-adult fiction that address the AIDS epidemic in the twenty-first century, many more young-adult novels, like Levithan's Boy Meets Boy and Moore's Hero do not. More often, they paint portraitures of gay life at the coming out stage and beyond, to the neglect of a complex sexuality that continuously (re)defines a queer individual's place within the greater social, political, and cultural structure. As Esther Saxey argues, "discourses of sexual identity help to create what they purport to describe. Thus the coming out story, which purports to describe a pre-existing sexual identity, is simultaneously contributing to the cultural construction of this identity" (5, emphasis hers). Yet the presencethe memory — of AIDS looms over the text, and the novel still contains the trace of what AIDS was/did to the gay community that came before. The trace of AIDS, though seemingly absent, bubbles through to the surface of the texts in different forms. One place the trace can be understood is in the way the novels tackle problems of identity. In these AIDS-free worlds, there are characters whose identity collapses and the struggles of not knowing oneself (a symptom of Holleran's phenomenological identity crisis) are displaced onto other queer characters.

\footnotetext{
${ }^{36}$ There has been, over the past several decades, a rather substantial collection of books that function as bibliographies of young adult gay literature which, more often than not, identify and track "problem" themes within the texts, including the presence of the AIDS epidemic. Laurel A. Clyde and Marjorie Lobban's Out of the Closet and Into the Classroom (1992) was one of the first, and it has been followed by Frances Ann Day's Lesbian and Gay Voices (2000), Michael Cart and Christine Jenkins' The Heart Has Its Reasons (2006), and Carlisle K. Webber's Gay, Lesbian, Bisexual, Transgender and Questioning Teen Literature (2010), to name a few.
} 
Separately, because it operates as a direct reaction to what has come before, gay pride wears the trace of the historical struggles of the gay community on its surface. As Heather Love argues:

Contemporary gay identity is produced out of the twentieth-century history of queer abjection: gay pride is a reverse or mirror image of gay shame, produced precisely against the realities it means to remedy. In the darkroom of liberation, the "negative" of the closet case or the isolated protogay child is developed into a photograph of an out, proud gay man. But the trace of those forgotten is visible right on the surface of this image, a ghostly sign of the reversibility of reverse discourse. (19-20)

And so gay pride, as a counter to the fear and shame of the collective gay community, functions as a trace of what has come before.

Throughout the AIDS epidemic, the gay community's relationship to gay pride, and equally as important, gay shame, was directly connected to its assimilationist agenda. AIDS had a major effect on the pride/shame dynamic; more specifically, AIDS enhanced shame. ${ }^{37}$ This shame took heightened and specific roles during the AIDS epidemic, and as we will see below, the shame of promiscuity paired with the shame of transmission, and, as the epidemic became manageable due to medical advancements, there was a transition toward the shame of surviving the plague when so many others had died. In 2004, Patrick Moore wrote about how the gay community needed to move beyond the shame — of AIDS, of sexuality, of being gay—-that consumed the community in the midst of the AIDS epidemic. Rather, the community needed to move past that shame in order to reclaim their liberated sexualities and sexual identities that were declared and celebrated throughout the 1960s and 70s. Moore writes:

${ }^{37}$ Paul Hoggett, analyzing several texts of Deborah Gould's research, argues, "the initial impact of the AIDS epidemic in the United States in the early 1980s was to enhance shame and repress pride" (83). 
Our connection at the moment is shame. We are a community of shame. Shame defines our view of a sexual past that segued into AIDS, confirming to us our worst fears about ourselves... Shame motivates our forward movement as we fearfully suppress images of gay people as sexual beings, encouraging instead nonthreatening roles (parent, homeowner, or campy friend) that prove "we're just like you." (xxi-xxii)

What Moore is arguing overall, and what many critics who came before and after him did as well, is that attacks that painted the sexuality of the gay community in the midst of the AIDS epidemic as 'something to be ashamed of' attempted to set the gay pride/rights movement back decades while making the struggle to be gay and proud more difficult. Dirk Gindt, writing about the connection between shame and sexual excess during the plague, argues, "AIDS panic, largely though not exclusively fuelled by homophobia, has since the beginning of the epidemic conflated gay sex and excess through the shame of gay promiscuity and sexual practices" (249). ${ }^{38}$ In Sky Gilbert's play I Have AIDS!, the lead character "is shamed for his promiscuous sexual life and also threatened with legal punishment even though he assures the social worker that he uses protection" (264). As Gindt argues, "Since gay sexuality, HIV/AIDS, and promiscuity were discursively linked from the start of the epidemic, it is no coincidence that there is a correlation between excess and (gay) shame produced by homophobic discourse" (259). Contracting AIDS was accompanied by a very specific sense of shame that somehow those within the gay community deserved the sickness, pain, and for too many, death sentence that attended the epidemic. "With AIDS, the shame is linked to an imputation of guilt... The unsafe behavior that produces AIDS is judged to be more than just weakness. It is indulgence, delinquency-

${ }^{38}$ Deborah Gould, in her analysis of shame, ambivalence and activism during the AIDS epidemic, essentially makes the same argument as Gindt, while noting that in some cases this shame was transformed into anger that fueled AIDS activism networks. 
addictions to chemicals that are illegal and to sex regarded as deviant," Susan Sontag argues (2425). "Getting the disease through a sexual practice is thought to be more willful, therefore deserves more blame" (26).

The AIDS epidemic also highlighted the specific shame that comes from the feminization of the male body; as modes of transmission became a focal point during the plague, the act of being penetrated was brought to the forefront of the discourse. Leo Bersani and Adam Phillips argue, "A potential sexual shame is inherent in being HIV-positive. For the overwhelming majority of HIV-positive gay men, to acknowledge being infected amounts to a sexual confession: I have been fucked" (33). Almost two decades before Bersani and Phillips, Cindy Patton addressed this specific form of AIDS shame by the feminization of the male body. "Bodies 'naturally' marked different were now branded unnatural through the somatic revelations of AIDS symptomatology. ... despite public hysteria about casual contagion, 'getting AIDS' required a private act, required 'taking it,' required feminization”' (Patton, Inventing 127, emphasis hers). And more recently, David Caron has personally experienced the shame that attends even a recent diagnosis of HIV, particularly at the moment of disclosure, whether that moment be at the initial diagnosis or during a visit to an emergency room: "To be a human being means to be no less but also no more than one, and shame's dehumanizing power consists in upsetting such a delicate balance from both sides at once” (Nearness 110).

The medical advancements that accompanied the "end" of the AIDS epidemic in the late 1990s, primarily by making the viral load undetectable in the HIV-positive body, also brought about a specific, though less-frequently discussed, form of gay shame. Survivor's shame affected both those who had, and who had not, contracted the virus, but nonetheless had outlived so many 
other members of the gay community. Ross Chambers, connecting the impact of the AIDS epidemic to that of the Holocaust, writes:

Giorgio Agamben has recently argued that the aftermath of Auschwitz is shame, that what remains, quel che resta, of the camps, their aftermath, is the shame of witness. Shame is the knowledge that the human can be outlived by the inhuman... The witness testifies, conversely, to the possibility of the human's survival of the inhuman, but only does so as the bearer of that shameful knowledge... (230)

Chambers' language here, through Agamben's, gives us a nod back to Sontag who argues specifically about AIDS that "[t]he most terrifying illnesses are those perceived not just as lethal but as dehumanizing" (38). Additionally, Monica Pearl, writing about Holleran's The Beauty of Men, addressed this specific form of AIDS epidemic-generated shame: "This is what induces his survivors' depression, the burden of knowing that survival could be thought of as a gift-a serendipitous gift but a gift nonetheless — that he does not have the capacity to redeem. ... Suffering from the guilt of surviving, [Lark] compare his own status and situation to the afflictions of those who died" (121). ${ }^{39}$ Although we are now able to render the virus weaker, saving and lengthening lives, that shame specific to the gay community that manifested itself throughout the AIDS epidemic continues on, still affecting the entire community.

${ }^{39}$ In a literature review of medical studies focusing on "Shame among people living with HIV" [PLWH], David S. Bennett, et al., noted that those studies seemed to "suggest that shame can hinder the use of important health-preserving behaviors" and "Shame also predicted worse physical health a year later ... and is associated with greater physical symptoms and reduced health-related quality of life among PLWH” (3). Bennett, et al., looked at nearly 50 studies that focused specifically on shame and stigma associated with PLWH. 
Gay pride functions by invoking the specter, or the possibility, of gay shame, specifically those forms developed and heightened during the AIDS epidemic, as its opposite. The binary logic at the heart of AIDS discourse (pure/impure, gay/straight, healthy/sick) produces this trace and it is the trace that undermines the binary. Both gay pride and gay shame always already contain the trace of each other, and the way the AIDS epidemic is ghosted in our current culture is invoked in those binaries. Essentially what I am arguing is that those things that formulate the ideology and phenomenology of AIDS remain as traces within the text—divorced, by the author, from their connection to the AIDS epidemic yet remaining as the presence of AIDS within the text. The inherently instructional nature of young adult literature ("do this; don't do that or such and such will happen") — even when the literature does not purport to be instructional—allows for an optimal space for a closer analysis of these traces.

Arriving in the opening years of the $21^{\text {st }}$ century, David Levithan's young adult gaythemed novel Boy Meets Boy paints a rosy, idyllic portrait of small town gay life. Boy Meets Boy is a classic teen romance but with two high school boys in the lead roles. The narrator Paul's inability to decide between Noah, the new and mysterious artist, and Kyle, Paul's ex who's come around looking for a second chance, occupies the primary narrative arc of the novel, and the young men's sexualities, while essential to their identities, are ultimately incidental within the world of the novel. Yet the novel faces its greatest confusion in its presentation of the character of Infinite Darlene, whose identity collapses in the mixing discourses of drag and trans-identities. Boy Meets Boy is as close to a queer utopia as we have yet seen, an argument Amy Pattee's essay "Sexual Fantasy" methodically develops. Essentially, Pattee argues that, "by presenting us with a fictional but recognizable ideal society, utopian fiction encourages active critique of the 'real' world outside its own literary boundaries" (157). Moreover, this society is framed outside of 
specific chronological boundaries, operating in the modern world with modern technologies, languages, and ideas yet apart from any one specific moment in time. Boy Meets Boy's function as a queer utopia means that many of the things that threaten a utopian vision must be ignored or overlooked in order for that happy society to continue. It is no small surprise that AIDS, and the epidemic it wrought, are overtly absent from the text; instead it is through Levithan's destabilization of identity that the trace of AIDS manifests itself.

Another modern young adult gay novel that attempts to ignore the AIDS epidemic is Perry Moore's novel Hero, which complicates the coming out story by continuing not only the theme of social acceptance in high school but by adding an additional layer of superpowers. Thom, Hero's narrator, has to come out as not only gay but also as a super-powered young man who is also the son of a notorious ex-hero blamed for the deaths of thousands. Hero's young protagonist also copes with sexual longings toward the sexy sports star, who also shares those desires. Moreover, Goran, the object of Thom's attraction, also shares in the secondary secret identity theme, coping with both sexuality and superpowers. By taking place outside of a structured historical time-period, Hero can avoid addressing the AIDS epidemic and the relationship between the gay community and disease. Unlike Boy Meets Boy, the novel focuses its primary narrative on the narrator's coming out story, even if Hero's narrative does double duty when it comes to coming out. Saxey notes that, apart from a few notable exceptions, “overall, coming out stories do not acknowledge the existence of HIV in any sustained way and do not seem to be influenced by AIDS writing" (68). While the texts of these two young adult gay novels do not explicitly (or even implicitly) address the AIDS epidemic, the impact of the epidemic cannot be ignored or overlooked. Thom's struggle with the binary conditions of gay pride / gay shame and sickness/health reveals the ways in which the AIDS epidemic is still 
ghosted within our culture. Instead the epidemic manifests itself in shadows-resurfacing in the ideological and phenomenological forces that surround and shape the young gay protagonists.

\section{PROBLEMS OF IDENTITY AS A TRACE OF AIDS IN BOY MEETS BOY}

In too many LGBT texts of the $21^{\text {st }}$ century, the AIDS epidemic is forgotten, relegated to a footnote, or worse, highlighted briefly through the death of a supporting character suffering from the syndrome. Yet AIDS still populates these texts, its impact on the gay community being so cataclysmic that its effects are still present, if only in the shadows and contradictions of the work. One place the trace of AIDS is made manifest is in the way gay literature tackles the problems of identity. In these texts that gloss over the AIDS epidemic, the identity of certain characters can collapse or become destabilized. Similar to Holleran's phenomenological identity crisis, the struggle of not knowing oneself is displaced onto other queer characters. Levithan's young adult gay novel Boy Meets Boy, while ostensibly striving to (re)present a queer utopia, cannot escape the after-effects of the AIDS epidemic, the trace of which is visible in the confusing identities of Infinite Darlene and Kyle. Levithan is doing something specific with his idealized construction of a queer utopia for his teen characters. "Literature has the ability to create reality, first in its pages, and then perhaps in the world of its readers," Levithan wrote in the question and answer portion that concluded the $10^{\text {th }}$ anniversary edition of the novel (192, emphasis his). Moreover he recognizes that despite the novel's utopian approach, the concepts of hate and bigotry still function on a separate level. "Even when they are absent from the page, they're there" (192). Levithan's approach to a queer utopia predates the work of José Esteban Muñoz, who later theorized critically about the usefulness of queer utopias. More specifically, utopian approaches operate specifically as tools for (potentially) getting around the AIDS 
epidemic. As Muñoz argues, "Utopia lets us imagine a space outside of heteronormativity. It permits us to conceptualize new worlds and realities that are not irrevocably constrained by the HIV/AIDS pandemic and institutionalized state homophobia" (35). And so Boy Meets Boy exists apart from the historical time/place where AIDS impacted gay community and its relationship to the larger heteronormative hegemony.

Set in a generic town in a generic community somewhere in America, Boy Meets Boy operates as a traditional teen rom-com novel where the main characters just happen to be gay. The novel's central conflict revolves around the budding relationship between Paul, the book's narrator, and Noah, the new boy Paul meets at a party. But when Paul kisses his ex-boyfriend Kyle in a moment of compassion, the new relationship is threatened. The rest of the novel is populated with a collection of characters generally filling some sort of high school archetype: jocks, nerds, popular kids, smart Asians, et cetera. Levithan's presentation of Infinite Darlene, the homecoming queen cum quarterback who wears a dress and jersey simultaneously, might challenge conceptions of masculinity but not stereotypes of athletes being popular, self-absorbed drama queens. A parallel plot-structure involves Chuck, another football player who was interested in Infinite Darlene and is now dating Joni, Paul's long-time bestie. Lastly, Levithan weaves in the story of Noah, a young gay kid from a neighboring town with conservative antigay parents.

Generally speaking, the critical discourse surrounding the novel has primarily focused on Levithan's unique queer utopian approach. William P. Banks argues, "In presenting a 'modern fairytale,' Levithan disrupts mythical constructions that continue to pervade American culture, particularly myths about gender, sexuality, and religion, and creates a space in a critical pedagogy for reenvisioning the options before us" (34). Boy Meets Boy successfully presents a 
town in which the primary conflicts arise not from the gay or queer identities of the characters but from generically heteronormative situations that arise out of the normalization of those identities. To return briefly to Pattee, she argues "The characters' sexualities and sexual identities are so unproblematic that they are introduced in practically banal terms, which serves to extend the narrative from 'gay assimilation' to 'separated utopia"” (165). Pattee is building off the work of Fred Fejes who argued that a separated utopia is one in which "the vision of gay desire and sexuality represented is totally separated from the problems of heterosexual/gay tension" (103). For Pattee, it is Levithan's presentation of Infinite Darlene that serves as confirmation of the novel's "separated utopia" status. "[A] figure like Infinite Darlene would likely be an outcast in a traditional school," Pattee states while analyzing Infinite Darlene's introduction at the school pep rally (166). Paul narrates the rally with his usual aplomb: "After an encore of Depeche Mode's 'Personal Jesus,' the principal's secretary asks for quiet and introduces this year's homecoming king and queen. Infinite Darlene strides out in a pink ball gown, covered in part by her quarterback jersey. The homecoming king, Dave Sprat, hangs from her arm, a good thirteen inches shorter than her (if you count the heels)" (Levithan 22). "This remarkable scene lifts the novel from one of mere gay assimilation to the fantasy level of what Fejes would call the 'separated utopia,'” Pattee argues (166). Pattee's approach, while an important critical construction, is not universally accepted. Thomas Crisp writes "Other texts [specifically Boy Meets Boy], which I will argue rely on magical realism to suspend reality, imagine away homophobia by showing gay characters building relationships in an environment relatively free of discrimination and downplaying the need to characterize gay partners as a 'masculine' and 'feminine' pair” (336). Crisp's use of magical realism to define Levithan's novel rejects the utopian approach favored by Pattee and others precisely because the text "reimagines 
'normal' by re-imaging 'reality' in ways that challenge readers to deconstruct both the novel and the contexts in which they live. ... [The novel] may feel like 'magic' for readers from the ways in which [it] de-center[s] privileged discourses and disrupt[s] what may have previously been taken as 'logical' or 'normal'" (340). Moreover, Crisp's approach to the novel challenges the heteronormative insistence on using binaries, such as masculine and/or feminine, to construct identities/couplings, which essentially works for the majority of the novel's primary characters.

But when the novel approaches the character of Infinite Darlene, the narrative can neither contain nor process the character's identity, reading it as confusing even within Paul's narration, until her identity seems to collapse from character to caricature. When Paul talks about Infinite Darlene, he uses female pronouns and acknowledges that at one time everyone knew Infinite Darlene under a male name: “I don’t know when Infinite Darlene and I first became friends. Perhaps it was back when she was still Daryl Heisenberg, but that's not very likely; few of us can remember what Daryl Heisenberg was like, since Infinite Darlene consumed him so completely" (15-16). This description seems to indicate a transgender transformation, in which Daryl transitions into Infinite Darlene. But the next paragraph, Paul's narration seems to confuse this: "The other drag queens in our school rarely sit with her at lunch; they say she doesn't take good enough care of her nails" (16). Levithan's use of "other" sees to acknowledge that Infinite Darlene is one among several drag queens that attend Paul's school, and not transgender. All this is not to take some essentialist position that demands drag queens can or cannot be transgendered. Rather, the primary identities of drag queens tend to be gay men who self-identify as such, and if Paul, or in a larger sense Levithan himself, wished to address this specific identity construct, the narrative had plenty of room for him to do so. 
Moreover, this identity confusion carries over into the reviews of the book. A reviewer for the School Library Journal mentions that "the school quarterback is a wily transgender youth popularly known as Infinite Darlene" (Goldsmith 81, emphasis mine), yet two years prior the same journal noted that "the cross-dressing homecoming queen is also the star quarterback" (Lewis 216, emphasis mine); meanwhile a reviewer for Horn Book Magazine describes her as 'the star quarterback, a drag queen named Infinite Darlene, [who] is also homecoming queen' (83, emphasis mine). Not incidentally, both the Publishers Weekly and Lambda Book Report reviews of Leviathan's novel also identify Infinite Darlene as a drag queen.

Compounding the issues surrounding the character of Infinite Darlene is the problematic ways in which she is represented, particularly when compared to the other LGBT representations in the text. Paul's narration emphasizes the ways in which she is different from the others, and more often than not, those differences are presented in a negative form. Consider Paul's description of her, and of how he "handles" her and her identity:

Now I really like Infinite Darlene. But among my friends, she's usually the last I introduce to new people. I have to prepare them. Because Infinite Darlene doesn't make the best first impression. She seems very full of herself. Which she is. It's only after you get to know her better that you realize that somehow she's managed to encompass all her friends within her own self-image, so that when she's acting full of herself, she's actually full of her close friends, too. (41)

Paul's idea that Infinite Darlene's own identity is actually an amalgamation of her friends' identities complicates the idea that there is or can be a coherent identity, and while Infinite Darlene's choice of the adjective "Infinite" is never clearly explained in Levithan's works, this 
moment might come the closest to explaining it. ${ }^{40}$ Levithan's characterization of Infinite Darlene's identity invokes a Deleuzian approach to ontology and identity. Considering the theories of Gilles Deleuze, Todd May argues, "We can engage in ontology ... that responds to the question of how one might live - when we cease to see it as a project of identity. We begin ontology when we abandon the search for conceptual stability and begin to see what there is in terms of difference rather than identity" (18-19). Infinite Darlene need not be based on some form of defining identity grounded in conceptual stability. Instead we can see her as that form of difference personified. Infinite Darlene stands out, even in Levithan's model queer utopia, precisely because of the way in which her otherness is (re)presented. Elsworth Rockefeller calls Infinite Darlene "a cliché" who "is consistently dramatic, gossipy, and brazen—a character seemingly added for entertainment value only" (520). Were she the main character, with a fully developed story arc, then Infinite Darlene's characteristics might have time and space to become more than stereotypes of the shameless queer kid who says whatever crosses her mind. But instead the narrative does little more than offer up Infinite Darlene as a mode of comic relief. Judith Hayn and Lisa Hazlett pick up on this portrayal when they argue that Boy Meets Boy is "populated with hilarious characters and situations; for example, Darlene, a transvestite, is Homecoming Queen and the quarterback of the football team. ${ }^{41}$ Significantly, Hayn and Hazlett distinguish the comical presentation of Infinite Darlene from the more fantastical elements of the

\footnotetext{
${ }^{40}$ This passage also nods to Walt Whitman's classic poem "Song of Myself” where he writes, "Do I contradict myself? / Very well then I contradict myself, / (I am large, I contain multitudes.)" (77).

${ }^{41}$ To clarify, Infinite Darlene is not a transvestite, which is generally defined as a heterosexual man who wears women's clothing for pleasure, sexual or otherwise, and traditionally uses male/masculine pronouns. Additionally, nowhere in the text is her name abbreviated to only "Darlene" rather it always appears as Infinite Darlene.
} 
novel, notably Levithan's "hate-free world where everyone can love without fear." Even in their analysis of the text, Infinite Darlene remains apart from the rest of the characters in the novel and its broad utopian goals.

Infinite Darlene consistently functions in a separate space within the novel. Paul's narrative, while in the process of establishing and developing the sexual identities of the main characters, treats Infinite Darlene's identity as one primarily in conflict—not with herself but with the choices of the other characters - and gives her little to no room for self-identification. Tison Pugh argues that Boy Meets Boy "showcases the ways in which knowledge of sexuality enhances children's lives and relationships, even at very young ages, and depicts in its full chaotic glory children's knowledge of sexuality" (163). Pugh continues by saying that "Levithan links sexuality with self-knowledge... indeed, how could one have a 'good sense of self' without knowledge of one's sexuality?" (163). But Pugh completely overlooks the character of Infinite Darlene, not mentioning her once in the otherwise developed three pages on Boy Meets Boy. Then by Pugh's estimation, identity and self-knowledge can be seen as well considered only if one overlooks the transgender character in the text.

Yet self-knowledge — even of one's own identity — is not the same thing as adhering to an identity category. Crisp argues that "Levithan is actively working against the construction of identity categories" and that as the author, Levithan can "intervene and offer readers (however momentarily) a range of identities and a number of 'possibilities'—recursive strategies intended to push readers to re-read the taxonomy of identity options" (341). In the case of Infinite Darlene, this possibility of identity is more clearly seen when Paul and his friend, "one of the Club Kids," Amber discuss the contentious relationship between Infinite Darlene and Trilby. Amber compares that conflict to one between the girl and guy who were competing for class 
valedictorian: "They want to beat each other, and at the same time they secretly want to be each other. ... They'll either kill each other or sleep together. The jury's still out" (Levithan 142-143, emphasis his). But Paul argues with her that Infinite Darlene and Trilby do not share this form of sexual tension, rather "they want to sleep with the same people" (143). Amber is challenging Paul's restricting perspective regarding whom his friends actually or might wish to have sex with by allowing for multiple identity categories. But Paul, despite his position as voice of the enlightened queer utopian youth, cannot accommodate a larger, more destabilized world-view: “Are you saying that Infinite Darlene is a lesbian?” Paul asks Amber (143, emphasis his). The limited perspective of Paul becomes the limitation of the text; as the arbitrator of the narrative, Paul's faults in understanding also keep the text from accomplishing more with its presentation of Infinite Darlene and provides the site where the trace emerges, despite the author, as pure disruption of identity.

Chuck's relationship with Infinite Darlene_-and more importantly, Chuck's use of pronouns when describing Infinite Darlene-is one of the places where identity collapses in the novel. Chuck's sexuality is never declared using a label, and is only (re)presented through descriptions of whom he loves or crushes on. Neither Paul nor Infinite Darlene nor Chuck are eager to label Chuck's sexual interests, only his emotional attachment to Infinite Darlene. As Saxey argues, "It's possible to have sex with another boy and remain straight, as long as the sex isn't discussed. ... Gay identity is essentially a matter of emotion and emotional literacy rather than of activity" (42). Chuck's dating and then rejection by Infinite Darlene means we cannot just dismiss Chuck's language as homophobic (or transphobic, if that term need apply). ${ }^{42}$

\footnotetext{
${ }^{42}$ Chuck's real sin in the book is that he's a superficial misogynist. Describing an actress he says, "She can't act, but she sure is a babe" (58).
} 
Several characters make gay jokes, including Chuck and Joni, both of whom are very gayfriendly, and again, Chuck chased after Infinite Darlene for a while in seeming full knowledge of her transgender (or drag queen) identity. But Chuck's use of pronouns, coupled with Paul's switching of the pronouns as a means of translating Chuck's statements, complicates our understanding of who Infinite Darlene is. Chuck whines to Paul about Infinite Darlene's attentions during football: “'He's more worried about breaking his nails than throwing the pigskin. ... He should just enter the beauty contests instead of heading onto the gridiron, if you know what I mean"' (57). But as Paul narrates, he changes/corrects Chuck's pronouns without acknowledging the change either verbally or internally through narration: "Oh I know what he means. He means: I had a crush on the quarterback and she didn't have a crush back, so now I'm going to bad-mouth her since I can't undo the crush I once had' (57, emphasis his).

Considering Chuck's interest in both Infinite Darlene and Joni, he appears to be heterosexual (though queer would also fit), and Crisp, and by extension Levithan, would want us to overlook these underdeveloped identities by assuming they are instead "recursive strategies" designed to make the reader question sexuality and identity.

Ultimately, the narrative of Boy Meets Boy-or at the very least, Paul's narration of the tale-cannot contain nor account for Infinite Darlene's sexuality and gender identity. This collapse of identity calls to mind the ways in which the AIDS epidemic distorted identity within the gay community as both the self and the other is seemingly rendered unknowable. Levithan, perhaps recognizing the limitations of the original novel, published a short story focusing solely on Infinite Darlene. "The Quarterback and the Cheerleader: A Valentine's Day Story" appears in the back of the $10^{\text {th }}$ anniversary edition of Boy Meets Boy, and recounts, from the perspective of an unnamed omniscient narrator, Infinite Darlene's first date with Cory Whitman, the male head 
cheerleader of an opposing school. Cory falls into the same vein as Chuck-an ostensibly heterosexual male into females. Or, as the unnamed narrator describes him, Cory is "single (and into girls)" (203). The narrator also uses a peculiar term of phrase when describing how Infinite Darlene attracts attention just by walking into a room. "The question of her original gender aside" (207), the narrator tosses out, as though this were a question, as though gender could somehow be "original" rather than performative, and as though all tall(er) women are automatically and always stared at when they enter the room. Even in this special narrative, crafted just for and around Infinite Darlene, identity collapses into performance.

Furthermore, at dinner Cory starts to ask the elephant-in-the-room question- the one about Infinite Darlene's gender identity—but his question is overridden/interrupted by Infinite Darlene's problematic use of coded language:

"How long have you been—“ Cory asks.

“So remarkable?” Infinite Darlene chimes in.

Cory smiles. "Yes. So remarkable." (208)

But even here, where Infinite Darlene takes center stage in her own story, the language slips: “"And you?' she asks. 'How long have you been so remarkable?"” (209). If "remarkable” is coded language for "transgender," then this question only works if Cory is also transgender. But the text gives no other indication that Cory identifies in such a manner. Moreover, their responses to the question "how long have you been?" reveal that they are answering separate questions. Infinite Darlene reveals that while she was born this way, for a while "I found myself forgetting to be remarkable. ... I wasn't denying the truth-I knew what the truth was - but I was denying myself the power to express it" (208). Cory's response to "how long have you been?" is pedestrian in comparison as he tells Infinite Darlene about "the first time I did a perfect 
cartwheel" (209). And so Infinite Darlene is never really clearly represented, certainly not in connection with her relationships to men, in no small part because the novel cannot properly accommodate her identity, gender, and sexuality without turning her into a comedic stereotype. This lack of knowledge — of the self and of others—recalls the phenomenological critique of AIDS in the previous chapter in which the epidemic obscures not only the self but also our ability to know/understand others within the gay community.

Within the narrative, Infinite Darlene is not the only character with identity issues. While hers are external— that is to say, generally presented by Paul and his limited/problematic narration —Kyle's identity problems is a part of the novel's overall plot. Following his break-up with Paul, Kyle is trying to reorient himself to come into a better understanding of what his sexuality is / might be. For Kyle, it is the loss of his aunt that triggers the revelation that Kyle still wishes he were with Paul: "My aunt died this weekend, ... and I decided that we should be together" (102). Sickness is disorienting, but his aunt's hospital room allows for a refocusing through a reorientation. Kyle's visit to the hospital room here calls back to the phenomenological ways in which the hospital room in the midst of AIDS functioned as a place for the self to be reoriented when the outside world — living it the midst of AIDS — was overwhelming and disorienting. When Kyle makes this confession to Paul, he speaks of how the space itself factored into his clearer understanding of himself. "I came to the room early on Saturday and I saw him curled up in the hospital bed, singing Beatles songs to her and looking her in the eye," he tells Paul. "You gave me something, Paul. And I don't think I realized it until I saw Tom with my aunt Maura. Then I knew what I wanted" (103). Tony understands Kyle's emotions through the construct of losing and being lost. Being lost is, in Tony's estimation, what Kyle is experiencing and what separates Kyle from Paul: "Kyle feels lost... And he knows you're not 
lost. You've never really been lost. You've felt lost. But you've never been lost" (151, emphasis his). Tony's own attempts at reorientation differ because he is the character that comes from another town - his reorientation occurs in the queer utopian world that is distinct from Tony's own hometown. For Tony, this utopia has a similar effect on reorientation that AIDS had; both the utopia and the epidemic reshaped the world around it. But unlike Kyle, Tony does not see himself as lost. "I know exactly where I am, what I'm up against," he tells Paul (151). And so in Kyle and Tony's identity issues, the novel recalls those moments of confusion and disorientation that, in a phenomenological sense, were hallmarks of living in the midst of AIDS.

The questions of identity in Boy Meets Boy operate as traces of what the AIDS epidemic has done to the gay community, what it has survived, and what it must acknowledge or ignore in order to move forward. There are other traces of AIDS which are found particularly in works that address what it means to be an LGBT young adult. In his examination of the evolution of GLBTQ literature for Young Adults, Michael Cart argues that Boy Meets Boy "is the only novel since the [Gay Young Adult] genre began in 1969 that has no hint of selfhatred" (sic). Cart is not exactly correct; he seems to be oversimplifying the queer characters of Chuck, Kyle, and Tony, but overall his point stands as a launching point for further analysis. In several texts, the conflicting/complementary binary of gay pride / gay shame often serves as a place where the impact of the AIDS epidemic can be examined.

\section{GAY PRIDE AND GAY SHAME AS A TRACE OF AIDS IN HERO}

Gay shame operates as the counter to gay pride, and the connected nature of both concepts function as a trace of the AIDS epidemic. And while gay shame existed prior to the AIDS epidemic, the shame of being gay and of having gay sex was enhanced throughout the 
plague. Since the mode of transmission of the virus was linked with the kind of sex being had, AIDS produced specific forms of shame that was confronted head-on in discussions of being healthy or sick, or of testing negative or positive for the virus. Binary representations of pride/shame and healthy/sick produce a trace of AIDS and it is the trace that undermines the binary. Gay pride and gay shame always already contain the trace of each other, and these binaries invoke the remnants of the AIDS epidemic still at work in our current culture. David Halperin and Valerie Traub recognize this pairing when they argue "Gay pride has never been able to separate itself entirely from shame, or to transcend shame. Gay pride does not even make sense without some reference to the shame of being gay" (3). ${ }^{43}$ The one reveals the other, gives the other purpose, context, and meaning. Indeed, Nadine Hubbs argues along similar lines, "the 'gay' that's been subsumed under 'pride,' and the 'shame' so long relegated to the queer, can no longer pass as divergent or discrete from one another. Rather, gay pride must bear, has always borne, a weight of shame — even as shame's chafe has polished the objects of gay pride" (115).

The pairing of gay pride with gay shame is a work that has progressed over the past several decades in critical research, and developed as it was complicated throughout the AIDS epidemic. Dwight Watson explores the theories of Vivienne Cass who, in 1984, developed a series of stages for gay identity development. Possible social alienation is a topic addressed early, in the second of Cass's stages, while identity pride develops during the $5^{\text {th }}$ stage (of six total) (qtd. in Watson 272). Alienation, Watson explains, "may cause [gays] to separate their

\footnotetext{
${ }^{43}$ Writing about their Gay Shame Conference, organized in 2002 and 2003, Halperin and Traub argue, "Gay Shame offers a refuge, a site of solidarity and belonging. It willingly embraces those queers whose identities or social markings make them feel out of place in gay pride's official ceremonies" (9). Additionally they write, "Gay Shame represents a new grassroots queer collectivity founded on principles of resistance to normalization' (9).
} 
homosexual behavior from their personal identities," while during the pride stage "people will allow themselves to be immersed in gay subcultures ... [and] may need help dealing with their anger and curbing their defensiveness" (272-273). Cass's identity development model brings the pride/shame binary into a medical discourse that has long been linked to the construction of the gay self. The AIDS epidemic only magnified this connection, while forcing the gay community to deal with its implications as the epidemic highlighted and publicized both the sexuality and sex acts of the gay community on a personal as well as communal level. Deborah B. Gould argues that "Gay shame, as well as lesbians' and gay men's ambivalence and their conscious and less than fully conscious efforts to navigate those contradictory feelings, significantly influenced their collective political responses to AIDS" ("Shame" 233). Even after the gay community distanced itself from the AIDS epidemic, the impact of the epidemic cannot be erased, nor can those specific forms of gay shame so intimately linked with the AIDS epidemic. And while the AIDS epidemic is absent from Hero, the conflicting constructs of gay shame and gay pride remain as traces of what has come before.

Moore's superhero-take on the classic coming out story, Hero follows the adventures of high school athlete Thom Creed as he comes into his sexual identity and superhero persona. Throughout the novel, Thom deals with his burgeoning powers and his sexual attraction to Goran, a star basketball player from another school who is secretly the ethically ambiguous Dark Hero, who is also gay. Thom's father Hal was formally a hero but now lives disgraced and in hiding, after being blamed for a mass genocide event when he was not actually at fault. ${ }^{44}$ The novel's primary plot centers around Thom's becoming a hero, uncovering and facing off against

\footnotetext{
${ }^{44}$ In a sense, the role of Thom's father in the novel's mass genocide event could be read as a way of placing AIDS "under erasure" in the text, that is to say, crossing it out while allowing it to still remain legible.
} 
a villain who is murdering heroes, and in the process revealing the truth about his own sexuality and his father's innocence. Along the way Thom shares his first man-on-man kiss with Simon Hess AKA the two-bit villain Ssnake, an incident that directly leads to Thom's outing when he serves as Ssnake's alibi. Bringing all this full-circle is Thom growing into his superpowers, though in his case they are defensive rather than offensive abilities: Thom can heal people by absorbing their sickness. The plot of Hero, then, deals fundamentally with issues of pride and shame as well as sickness and health, and navigates both of these binaries on the initial level of super-heroics and the secondary level of sexual identity. By looking at the shame surrounding Thom's outing, as well as a closer consideration of Thom's healing abilities, we can critique the ways in which these binaries bring forward the trace of the AIDS epidemic and its impact on the next generation of the gay community.

One of Hero's fundamental differences from Boy Meets Boy involves the former novel's central plot of coming out. Where Levithan's narrator is out and proud, the central storyline of Moore's Hero involves Thom's progress in coming out, as both gay and super-powered. Michael Cart and Christine A. Jenkins describe many young adult LGBT novels as "stories of 'homosexual visibility" involving the coming out process, arguing that "this revelation may occur at any point in the story with much of its dramatic tension arising from what might happen when the invisible is made visible" (xx, emphasis theirs). Another primary category of this genre of literature is "gay assimilation" in which the "stories include people who "just happen to be gay' in the same way that someone 'just happens' to be left-handed or have red hair" (xx). Katherine Mason, April Brannon, and Elle Yarbough argue that these two categories are on 
"opposite end[s] of the spectrum.. ${ }^{45}$ Perhaps more important for our consideration, in their article Katherine Mason, et al. highlight Hero as a novel that features both of these categories of LGBT young adult content without explaining their reasoning. Thom certainly fits the primary category, as he spends chapters worrying about what will happen when/if he is found out. But ultimately being gay ends up being treated a lot like being super-powered; the world is full of them, gays and superheroes alike, and everyone just needs to get over it—and they do.

But the central narrative of Thom's coming story is structured around the shame he feels over his sexuality / sexual identity. For a young adult novel, Thom's descriptions are rather evocative, describing not only his sexual interests including "a nice hairy chest" but also specific activities like "the last thing I needed was to get caught jerking off to an oiled muscle stud" (Moore 40-41). Yet ultimately, in both his Internet fantasies and his first sexual interaction, Thom's actual sexual activity only goes so far as fumbling around and kissing (204-205). After Thom passes the test to join the superhero team he auditions for, he decides to visit the local gay bar he has passed by several times before. But his trip to the bar is prematurely halted when he feels like he might be being watched in the parking lot. More than the fear of being outed, though he certainly feels that fear, Thom experiences a sense of shame that somehow what he is doing, and by extension who he is, might be wrong or bad. Hiding behind a car in the dark parking lot, Thom thinks to himself, "Maybe my head was playing tricks on me for doing something I knew I shouldn't be doing. This was clearly not my scene; I was here out of desperation. Didn't I have

${ }^{45}$ Cart and Jenkins have a third category, "queer consciousness," which involves stories that feature not only the LGBT community but also its family/community of allies (xx). Mason, et al. do not place this category on any sort of continuum with the other 2 categories, probably since it, unlike the other two categories, does not directly connect to the coming out process (or lack thereof). 
standards? Didn't I want more than this? Suddenly the thought of someone finding me here turned my stomach" (134). Thom's shame is so closely linked to his pride; his success tightly woven with this fear of being found out or perceived as bad.

Thom's gay shame is only magnified when it comes to his early sexual encountermaking out with Simon in the car - and the shame of this situation ghosts/masks the underlying issues of both sick/well as well as pure/impure. Thom is not ashamed during the kiss; he's nervous, and curious, and worried — and immediately after when Dark Hero just sort of turns up and then disappears quickly, Thom is worried about being caught. But Thom's true moments of shame come later when the villain Ssnake is captured and accused of murdering the hero the King of the Sea. As he is revealed, Thom recognizes him as Simon, the man he was making out with in a car at the time of the King of the Sea's murder. Thom's initial sense of shame and guilt is over the fact that while Simon used his real name when they made out, Thom had lied and used the alias John. But that isn't the only moment of shame for Thom. "After that shame passed, a new one overwhelmed me," Thom narrates (270). Thom was afraid that Ssnake would recognize him and tell the heroes about their encounter. "Guilt rolled through me and gained the momentum of an avalanche," he tells us (270). But this specific guilt has nothing to do with Ssnake's innocence or Thom's ability to tell the truth. Rather, Thom is ashamed of and wracked with guilt over his sexual activity with another man: "I'd be outed, and they'd kick me out of the League faster than I could say homo" (270, emphasis his). It isn't until after Thom gets over this initial rush of fear and shame that he logically figures out that he is Ssnake's alibi. But in order to do so, he would have to out himself. "This would change my whole life forever. There would be no turning back," Thom worries (273). Yet this is where the opposite moment of pride comes out. It is not a gaudy pride, but the recognition that being true to oneself is the most important 
thing. As Thom phrases it, "Once in a while, life gives you a chance to measure your worth" (273). Thom struggles as he walks forward to his own outing; "But after that first step, I walked with a little more assurance" (273). Gay pride and gay shame literally produce Thom's identity here. Ashamed of who he is or who he might be, he is equally ashamed that he might be immoral—something linked to his role as an alibi for Simon—as Thom is not just outing his sexual identity but also his sexual activity, that is to say, how he was with another man. Even if Thom does not go into any details, and he does not, he still feels the public shaming that somehow his own sexual desires/interests have an impact on the greater community. ${ }^{46}$ And yet, despite this internal shame, Thom must become proud of his own self in order to step forward.

Once Thom is out of the closet, he still struggles with the shame of being gay. But actually being gay is never the question. Thom recognizes and owns his sexual identity and activity, including the kiss with Simon and his desire to do much more than that with Goran, for whom he has both sexual and romantic feelings. Terence Beck, discussing Hero and other gay young adult fiction, argues that there is "the absence of a struggle to self-identify as gay communicates, at least for [Thom], that knowing one's sexuality is a matter of paying attention to desire. ... sexuality is navigated based on whom they desire and the pictures they seek out on the Internet" (252). Yet, Hero, unlike Boy Meets Boy, does not challenge the boundaries of sexual desire: "the conventional notion that people are either gay or straight is left undisturbed

\footnotetext{
${ }^{46}$ To a much lesser extent, the trace of the gay shame of surviving a horrific cataclysmic event also comes into play in the novel. Thom's father is considered responsible for the destruction of the Wilson Tower, an event that led to the death of over nineteen thousand people (Moore 291). I say lesser extent because a) Thom was a child when the destruction occurred, b) Thom's father is not actually guilty, and c) as such, Thom feels no real guilt for surviving when others died.
} 
... reinforce[ing] an expanded notion of sexuality that continues to leave out those young people who do not fit neatly into the well-defined categories of gay or straight" (252).

Following his big outing, Thom comes home to find his father washing "faggot" off the garage door (Moore 280), the same slur he was called on the basketball court at the novel's start (21). What Judith Butler writes about the word "queer" in Bodies That Matter resonates in the way Hero uses the word "faggot." "The term 'queer' has operated as one linguistic practice whose purpose has been the shaming of the subject it names or, rather, the producing of a subject through that shaming interpellation," Butler argues (226, emphasis hers). "Faggot," particularly when used on the basketball court directly in Thom's face but also when painted on the family garage, functions as a shaming interpellation, both hailing and deriding Thom's identity. But Thom did not race right home following his outing. Turning down the offer of a ride home, Thom chooses to isolate himself and walk: "I needed to be alone for a while. I needed to think about what was coming next" (Moore 279). As Halperin and Traub argue, "gay pride has never managed entirely to overcome the mutual hostility and self-imposed isolation of the shamed" (4), and so Thom needs to take some time for himself. When we see gay shame, we cannot help but recognize gay pride, and it is the need for gay pride that calls out the community's overwhelming sense of shame. But as this binary functions as a trace of AIDS, so does that trace help us to undermine/dismantle the binary itself. They have always already been paired, before the epidemic, but the AIDS epidemic gives us a new space in which to critique those pairings. As the epidemic taught us, shame need not be isolating, it can be shared, and there can even be pride in both suffering and conquering that suffering. And in this way then the binary of pride/shame is intricately inked to the pairing of healthy/sick within the gay community. 
It is no small accident, then, that Thom's central superpower is one that directly challenges the binary of sickness and wellness. As Thom discovers his abilities he learns that he can absorb sickness. Thom's powers challenge the binary of sick/well; in Moore's world, a gay man can heal the sick with the touch of his hands. The first major demonstration of Thom's powers comes early in the novel when Goran is tripped during a basketball game and breaks his tibia. Thom even describes seeing the bone breaking out of the skin. "I can't explain why I did what I did next," Thom narrates. "I was propelled by a force deep within me that I didn't understand" (19). As Thom lays his hands on Goran's leg, "My hands suddenly felt scalding hot ... I felt dizzy, and my eyelids grew heavy" (20). The language Thom uses to describe why he heals Goran - this force deep within himself — mirrors the language later used when Thom steps forward to out himself: "I felt a surge of energy well up from my feet, through my heart, to my head," he narrates (273). Both sickness/health and pride/shame are forces that move and control Thom, as though they were fundamental components of his identity.

Moore uses this imagery of power within Thom to destabilize these binaries. During a fight between his team and a group of super-villains, Thom is thrown and crashes into the burn ward of a children's hospital. "In theory I was supposed to help my team," he narrates (168). Instead a little girl takes his hand, and as he begins healing her, the children all link hands: “Children calmly emerged from their rooms and wandered over in our direction, like they'd heard there was cake in the playroom, irresistibly drawn to the heat pumping in and out of my hands" (169). The heat and pain is intense for Thom, growing and growing within him, until suddenly it isn't any longer as though he crossed some sort of "threshold" (169). Yet, in the scene's climactic moment, Thom is completely overwhelmed: "all of a sudden I felt an explosion somewhere deep inside me, like all my organs had burst with joy and anguish and happiness and 
pain" (169). And while Moore's writing here not so subtly invokes la petite mort, the little death that accompanies the moment of orgasm, it also reaffirms the positioning of sickness and health as fundamental components of Thom's being. But Thom's ability is destabilizing; he can heal the sick. He can collapse the binary of sickness and health through healing. And his touch connects him to others-helps him see others in a new way. The healing power helps Thom know others, which in turn reminds us of both how little Thom really knows ${ }^{47}$ and how little we know of others. Within these moments of Hero, the trace of AIDS is that what was once infection through viral transmission is now reimagined as healing, its inversion. Here, human interaction (and implicitly, gay sexuality) becomes a different sort of comingling of bodies based on love and spirituality rather than contagion.

\section{CONCLUDING THOUGHTS}

The title of this chapter, "If Anybody Notices, Nobody Cares," takes it name from the scene in Boy Meets Boy in which Paul and Noah walk through town hand in hand (Levithan 65). Levithan is using the moment to paint his utopian picture of homosexuality as fully assimilated into this culture, so much so that it becomes an everyday part of the town's background. But in a larger sense, this also speaks to the many other things that go either unnoticed or uncared for. Moreover, it both ignores and calls to mind what things must be ignored in order for this assimilationist fantasy to take place. There cannot be any overt sexuality, otherwise people would notice; there cannot be any shame, otherwise people would notice; there cannot be any

\footnotetext{
${ }^{47}$ As Thom's teammate Ruth tells him, "If you really want to be a good healer, you gotta know who needs healing" (Moore 220). Throughout this scene, and in several others, there are overt allusions to Christ, in particular to his healing abilities. However, I am suggesting that there is much more to these scenes than just Christ imagery.
} 
sickness, and certainly no AIDS, otherwise people would notice. And then they would care. As Deborah Gould argues, "Through the rhetoric of gay responsibility, pride and respectability became tightly linked: a proud gay identity now derived from gay respectability and required it as well" ("Shame" 237).

But neither Boy Meets Boy nor Hero presents a world quite like ours. While the former is more utopian than the latter, neither novel (re)presents a world that actually exists. Because there can be no gay utopia if the specter of the plague, and the homophobia it ramped up, looms over that culture, Paul and his friends cannot live in a world touched by AIDS. Because Thom can never heal the actual plague of AIDS, he cannot exist in a world where such a plague exists. And so what we are left with are the traces of an epidemic in worlds without plague because the narratives demand it. But the impact of AIDS is too great to be ignored-it leaves its mark in contradictions and signs, in how writers engage their characters with such presences and absences, and in how the collapsing binaries and phenomenological structures of the epidemic are concealed and revealed. 


\section{Conclusion}

"The Legacy of AIDS": The Paradox of Living With and Ending an Epidemic

AIDS isn't now a pandemic that affects everyone; it is a chronic illness, a parasite leeching of the disparity between genders, social minorities, geographical locations and privilege. But most of all, AIDS is a disease of stigma, erotophobia and shame about gender and sexual expression. (Ibáñez Carrasco 20)

In July of 2016, the Public Broadcasting Service (PBS) aired a six-part series on its NewsHour program entitled "The End of AIDS?" The documentary focused on six different places all around the world, including San Francisco, Atlanta, New York, South Africa, Kenya, and Rwanda, and their efforts to curtail the AIDS epidemic through prevention and treatment programs. NewsHour looked specifically at what steps these cities and countries were taking to "end AIDS" by focusing on how they are addressing the initiatives proposed by the Joint United Nations Programme on HIV and AIDS (UNAIDS). UNAIDS's primary effort is called "the '9090-90' strategy: it involves getting $90 \%$ of people infected with the virus tested, $90 \%$ of HIVpositive individuals connected to treatment and $90 \%$ of them taking medication consistently enough that the virus is suppressed in their blood - making them far less likely to spread the virus to others" ("PBS NewsHour"). This is the future of AIDS: until there is a cure governments and health organizations alike work to reduce the transmission and detectability of the virus while improving the care and treatment programs of those already infected. In San Francisco, PBS NewsHour examined the case of Luis Canales, who was taking PrEP before he realized he was already HIV positive (despite medical advancements, there is still a delay between 
contracting the virus and when it shows up in tests). Luis's circumstances are special, and as such offer a promising potential for better understanding what a cure might look like:

The moment the HIV was detected, Luis began taking antiretroviral medications... HIV is now at such low levels in his body that doctors are studying him to see if they can learn any clues about a possible cure for HIV... In the past two years, doctors have scoured Luis' blood, bone marrow, lymph nodes, guts, spinal cord for HIV. The virus is nowhere to be found. ("The End of AIDS?")

Because Canales started treatments so early, doctors are hopeful that early detection paired with rapid retroviral medications might lead to a cure. Canales is a model representative of San Francisco's progressive and ambitious AIDS initiative "Getting to Zero" by 2030 which seeks to cut HIV infections and death down to zero by the year 2030.

In New York City, where 70\% of new cases are minorities, NewsHour examined efforts around both providing clean needles through delivery-based needle exchanges as well as creative methods for finding the disenfranchised who may need care. Needle-exchange programs like those in New York address HIV infections apart from human sexuality. The sharing of needles creates localized HIV outbreaks, including a 2014-2016 highly publicized outbreak in Scott County, Indiana where in a couple of years 181 people contracted HIV. The state government, led by then governor Michael Pence who was long-opposed to needle exchange programs, only authorized short-term needle exchanges as an immediate response to the outbreak, while still insisting, despite all evidence to the contrary that such programs work, that they were "still opposed to needle exchange programs and stood by the former law banning them" (Gross). Homelessness is also a major roadblock to the prevention and treatment of HIV, and efforts in New York City, like Housing Works, help to meet the needs of the HIV homeless in New York 
while also providing treatment. Homelessness, like needle exchanges, are larger cultural areas that require navigating in order to make gains in the war against AIDS. And yet while they are culturally separate from concerns of sexuality and sexual immorality, needle-exchanges and homelessness are still linked with issues of shame, disease, and disreputable behaviors by the hegemony that somehow views the people suffering as deserving of what they get.

Beyond the borders of the US, efforts to combat the epidemic are faced with the unenviable task of overcoming certain ideologies surrounding the AIDS epidemic. NewsHour reports on how, on an island in Lake Victoria, Kenya, the fisherman are "reluctant" to get tested, because their culture "does not make seeking healthcare a manly thing” (“The End of AIDS?"). As a result, the clinics there argue the economic hardships that come with getting sickregardless of whether or not you are HIV-positive- because not being able to work means a loss of income. Moreover, because the stigma of AIDS still persists, clinics offer HIV testing alongside a battery of other testing options, including diabetes, hypertension, and more. More recently, and in stark contrast to the efforts of Kenya, Rwanda, and South Africa highlighted in NewsHour, in February of 2017, Tanzania shut down several AIDS clinics because they were deemed to promote male ${ }^{48}$ homosexual sex acts, which are illegal there. "The government announced it was stopping many private health centers from providing AIDS-related services, accusing them of providing services to homosexuals. 'We have suspended the provision of HIV and AIDS services at at least 40 drop-in centers operated by NGOs countrywide, after it was established that the centers were promoting homosexuality, which is against Tanzania's laws,' Health Minister Ummy Mwalimu said in a press conference” (“Tanzania”). Women face other difficulties and ideological roadblocks when it comes to the prevention and treatment of HIV. As

\footnotetext{
${ }^{48}$ Lesbian sex acts are legal in Tanzania.
} 
an HIV positive woman in KwaZulu-Natal, South Africa explains to NewsHour, "It's our culture that we need to be submissive to men, because we cannot really say no to men, and no to sex. Especially no to unprotected sex" (“The End of AIDS?"). Altogether, political and religious ideologies surrounding poverty and the stigma of AIDS conflict with the progressive movements combatting the spread of HIV and assisting with the health and wellbeing of those already infected.

Over the past few decades there has been less homophobia surrounding the AIDS epidemic in America. This is in some part due to the uncoupling of the AIDS epidemic from the gay community. Medical advancements meant people were no longer dying of AIDS, and so members of the gay community focused their efforts on altering public perception in order to secure civil rights, including marriage. The stigma surrounding AIDS shifted, and as the epidemic infected more and more outside of the white gay community, issues of class and race came to the forefront. Today ideologies surrounding poverty in America dictate prevention and treatment procedures, while homophobic ideologies continue to dominate how AIDS is handled in Africa and other parts of the world.

\section{IDEOLOGIES AND PHENOMENOLOGIES OF AIDS}

Throughout this dissertation, I have developed several foundational theoretical structures that, while present within the gay literature of the past three decades, have gone largely unrecognized. The ideologies that surround AIDS in America are less about actual actions and more about with the imaginary possibilities of such actions and how such movements challenge or uphold existing dominant structures. For years the heterosexual hegemony convinced itself that since they do not participate in gross, risky, or obscene sex acts they were not susceptible to 
AIDS. Alongside this, many within the gay community believed that if they were to lose their ability to engage in sex however they saw fit, they might lose not only their communal identity but also risked losing the progress towards civil rights they had fought so hard for. These and other ideologies attempted to process the incomprehensible Real of the virus, to make it comprehensible. The first two chapters of this dissertation looked closely at those ideologies, and specifically, how they were made manifest in the plays of Larry Kramer and Tony Kushner. Amidst the struggles of the AIDS epidemic, the gay community structured much of its discourse around what constitutes a gay identity and what it means to be a part of a larger gay community. Sexual desire, sex acts, and sexual health, and the policing of the boundaries of those ideas, became the centerpieces of gay identity. Both Kramer and Kushner consider gay identity and community from these vantage points, while challenging what approaches to developing a collective identity might be most successful. Kramer struggles to understand how a gay community, under siege from both the epidemic and the homophobic culture surrounding it, can continue to use sex as the foundation of its identity. Kushner, like Kramer, also looks to craft a cultural identity apart from "immoral" sex acts that can potentially lead to an early grave. But both plays must craft intricate ideological fantasies that overlook the amoral nature of the virus in the midst of the AIDS epidemic. Ultimately Kramer and Kushner provide us with alternative means for defining the gay community, relying on shared communal experiences, some of which may be sexual in nature but not necessarily, and for reconsidering the relationship between the gay community and the heteronormative, and at times homophobic, hegemony.

Beyond this ideological approach, there is a phenomenological approach to the AIDS epidemic that allows us to discuss the connections between the virus and the individual human bodies living in the midst of AIDS. Addressing a phenomenology of AIDS helps us to examine 
what it feels like to live and to be lived in during the AIDS epidemic. Alongside the novels and short writings of Andrew Holleran, I utilized a phenomenology of AIDS in order to analyze how the epidemic first disorients and then reorients individual perceptions; more precisely, AIDS both develops and ruptures identities simultaneously. Within Holleran's writing, physical spaces such as New York City or a hospital room and larger societal constructs including language each function as tools not only of disorientation but also of reorientation during the AIDS epidemic. The ways in which HIV restructured life within the gay community connect directly with another phenomenological understanding of the AIDS epidemic: the virus causes me to become no longer be transparent to myself; rather I become an unknowable, alien object to myself. Throughout Holleran's writings, he argues that AIDS makes the body/self independent of itself. Lark and his friends, for example, struggle with knowing themselves as their mental and physical health are under siege due to the uncertainties surrounding the contraction, transmission, testing, and treatment of the virus. And while many of those conflicts have been resolved in the decades since Holleran wrote, there are still traces of confusion and concern and a level of the unknown when it comes to HIV/AIDS.

Medical advancements have changed how we process and/or treat the epidemic within our community, so AIDS has fallen away from our collective consciousness, but a trace remains. This trace takes many different forms, some of which connect directly to the phenomenology of AIDS developed earlier in this dissertation. In $21^{\text {st }}$ century novels where AIDS is, on the surface level, absent from the text, the trace of AIDS still bubbles through to the surface. Within these texts there are characters, including David Levithan's Infinite Darlene, whose identity collapses, and the struggles of not knowing oneself (recalling the phenomenological identity crisis found in Holleran's texts) are displaced onto other queer characters. Another trace of the AIDS epidemic 
can be understood through an analysis of the gay community's relationship to both gay pride and gay shame. Gay pride shows the trace of the struggles of the gay community on its surface, precisely because it operates as a direct reaction to the historical challenges that have come before and the gay shame that developed through those challenges. The AIDS epidemic enhanced gay shame, and in turn gay pride functions by invoking the possibility of gay shame as its opposite. These ideas of pride and shame, visible within the novels, are also visible with the larger gay community where AIDS, though ostensibly relegated to a prior historical moment, is still being navigated and processed whether or not we are directly acknowledging it.

\section{WHERE DO WE GO FROM HERE?}

In the introduction to this dissertation, I argued that one of the reasons this dissertation focused on white gay male experiences was that African-Americans, women, and other minority cultures engage and process the epidemic differently than white American men. It would be a disservice to lump them in with the same analysis or tack them on as afterthoughts throughout. These separate experiences are distinguishable in the current HIV infection rates. In findings released in February of 2017, the Centers for Disease Control and Prevention (CDC) announced major declines overall in the rates in which men who have sex with men (MSM) in America were infected with HIV. As POZ reported,

CDC researchers estimated that between 2008 and 2014, HIV infection rates declined: ... 18 percent among young MSM ages 13 to 24 , from 9,400 to 7,700; and 18 percent among white MSM, from 9,000 to 7,400. MSM as a whole were the only major risk category that did not see a decline during the six-year period; the HIV incidence for this group 
remained stable, a finding that was still promising news, since during the preceeding [sic] years the HIV rate rose among MSM. (“After”)

In this same study, the CDC released numbers that showed that despite the decline for white gay and bisexual men, infection rates were "stable" at "about 10,000 infections per year among black gay and bisexual men" while annual infection rates were increasing by "20 percent among Latino gay and bisexual males (from 6,100 to 7,300)" ("New"). Clearly minority cultures are being treated differently and impacted distinctly from the white gay community, and the forces at work in and on those communities should be addressed directly.

Moving forward, I can see a project where the ideologies and phenomenologies of AIDS outlined in this dissertation are applied to, and reconsidered in light of, black, women, and other minority literatures. Such work has already begun on a cultural level. The independent 2007 documentary The Aids Chronicles: Here To Represent "is a focused look at the social and cultural impact of AIDS on the large African American community of the city of Atlanta" (Barash). Bailey Barash's film looks specifically at the ideologies of religion, poverty, and race in Atlanta that effect how the AIDS epidemic is approached. PBS's NewHour also focused an episode on HIV prevention and treatment in the Black community in Atlanta. "Gay black men don't engage in higher risk behaviors than say gay white men; repeated studies have proven that. They often have fewer partners and use condoms more," NewsHour reported ("The End of AIDS?”). Instead, easy access to care is the greater roadblock to better health, and the poverty and widespread infection rates throughout Atlanta only exacerbate the problem. And so further analysis and consideration of these material conditions and the ideologies that lead to them, particularly how they are represented in the literature and art of the past forty years, is required. How are these specific experiences with poverty and stigma similar to or different from those 
experienced by white men, or to narratives in larger gay cities in the north and west (New York City and San Francisco, for example)? The homophobia displayed by the hegemony during the first couple decades of the AIDS epidemic has been displaced onto poor minority communities, as conflicts of class have primarily replaced homophobic ones. The notion that the poor somehow deserve to be poor and therefore are less deserving of proper healthcare access and treatment is an ideology rooted in individualistic ideals.

Outside of America, other ideologies may be at work and need specific consideration. Parts of Africa where homosexuality is criminalized operate under the premise that a person is a heterosexual who commits a gay sex act (a crime or a sin), not that one's identity is by definition homosexual. Does the gay community outside of the United States use sexual desire and sex acts as defining characteristics of an identity? Are there other possibilities of organizing a community available to them outside of the homophobic constraints of the hegemony? When NewsHour looked at the AIDS epidemic in Africa, their efforts were largely centered on the heterosexual populations affected (and infected) by the virus. The discourses of the African gay community need further analysis, particularly in how their literature reflects their own ideological approaches to the epidemic, and what the gay community in America might learn from those ideologies. Moreover, religion still plays a major factor in how minority communities address the AIDS epidemic, and the ideologies at play in both African American and Latin American communities need to be considered in detail.

Women, especially black women, need to have their voices heard and understood when it comes to the AIDS epidemic. According to the CDC's most recent numbers, "Women made up $19 \%(8,328)$ of the estimated 44,073 new HIV diagnoses in the United States in 2014" ("HIV Among”). Moreover, "Black/African American and Hispanic/Latina women continue to be 
disproportionately affected by HIV, compared with women of other races/ethnicities," the CDC reports. "Of the total estimated number of women living with diagnosed HIV at the end of 2013, $61 \%(137,504)$ were African American, 17\% $(39,177)$ were white, and 17\% $(38,664)$ were Hispanics/Latinas" ("HIV Among”). Women also face specific prevention challenges, including the fact that whether sex is vaginal or anal, the receptive partner has a much greater risk level for contracting the virus than the penetrating partner. Additionally, the CDC notes, "The greater number of people living with HIV (prevalence) in African American and Hispanic/Latino communities and the fact that people tend to have sex with partners of the same race/ethnicity mean that women from these communities face a greater risk of HIV infection with each new sexual encounter" (“HIV Among”).

And finally, phenomenological approaches_-specifically ones that mirror the philosophical approach of this dissertation - have largely gone ignored when it comes to the AIDS epidemic. Questions of self and identity need to be considered across all communities, regardless of racial, gender, or national boundaries. Analyzing how the disorientation and subsequent reorientation of the AIDS epidemic affects different identities and cultural groups can potentially lead to new approaches to selfhood and subjectivity that have gone previously unconsidered. And these issues bleed over into real-world, immediate problems with severe medical, legal, and social implications. As Francisco Ibáñez Carrasco writes, “the legacy of AIDS is cumulative and here to stay for decades" (16). Medical advancements have changed how we treat and care for the infected, yet other medical issues still arise. "The old-fashioned opportunistic illnesses... are not killing us as much as a complex combo of long-term effects caused by HIV retrovirals. The celebrated 'cocktail' is simpler, but in the long run we pay the price in heart, liver and kidney failure or musculoskeletal conditions," Ibáñez Carrasco argues 
(20). Moreover, the social and medical stigma attached to HIV still remains, though in different forms than decades past, and the criminalization of the transmission of HIV remains a major issue for people living with HIV. How we approach the literature of AIDS can help to broaden our understandings of what it means to be living with HIV in different cultures and communities around the globe, and there is much work to be done. 


\section{Works Cited}

The ACT UP / NY Women and AIDS Book Group. Women, AIDS, and Activism. South End Press, 1992.

“After Two Decades of Stagnation, U.S. HIV Infection Rate Falls.” Poz, 15 Feb. 2017, https://www.poz.com/article/two-decades-stagnation-us-hiv-infection-rate-falls

Ahmed, Sara. Queer Phenomenology: Orientations, Objects, Others. Duke UP, 2006.

Alexander, Priscilla. "Bathhouses and Brothels: Symbolic Sites in Discourse and Practice." Policing Public Sex: Queer Politics and the Future of AIDS Activism. Eds. Dangerous Bedfellows. South End Press, 1996. pp. 221-249.

Allen, Peter Lewis. The Wages of Sin: Sex and Disease, Past and Present. U of Chicago P, 2000.

Althusser, Louis. "Ideology and Ideological State Apparatuses.” Lenin and Philosophy, and other essays. Monthly Review Press, 1971.

Anderson, Benedict. Imagined Communities: Reflections on the Origin and Spread of Nationalism. Verso, 1991.

Andriote, John-Manuel. Victory Deferred: How AIDS Changed Gay Life in America. U Chicago P, 1999.

Banks, William P. "Literacy, Sexuality, and the Value(s) of Queer Young Adult Literatures." The English Journal, vol. 98, no. 4, Mar. 2009, pp. 33-36.

Barash, Bailey. The Aids Chronicles: Here To Represent. 2007. http://www.snagfilms.com/films/title/the_aids_chronicles_here_to_represent

Barnett, Claudia. “AIDS = Purgatory: Prior Walter's Prophecy and Angels in America." Modern 
Drama, vol. 53, no. 4, Winter 2010, pp. 471-494.

Beachy, Stephen. "20+, HIV+." The New York Times Magazine, 17 Apr. 1994, pp. 52-53.

Bechtel, Roger. “'A Kind of Painful Progress': The Benjaminian Dialectics of Angels in America." Journal of Dramatic Theory and Criticism, vol. 16, no. 1, Fall 2001, pp. 99-121.

Beck, Terence A. "Conceptions of Sexuality and Coming Out in Three Young Adult Novels: A Review of Hero, Sprout, and In Mike We Trust." Journal of LGBT Youth, no. 10, 2013, pp. $249-255$.

Benjamin, Walter. "Theses on the Philosophy of History." Illuminations. Ed. Hannah Arendt. Trans. Harry Zohn. Shocken Books, 1968. pp. 253-264.

Bennett, David S., et al. "Shame Among People Living With HIV: A Literature Review." AIDS Care: Psychological and Socio-medical Aspects of HIV/AIDS, vol. 28, no. 1, Jan. 2016, pp. 87-91.

Bergman, David. Gaiety Transfigured: Gay Self-Representation in American Literature. U of Wisconsin P, 1991.

Berkowitz, Richard and Michael Callen. How to Have Sex in an Epidemic: One Approach. News From the Front Publications, 1983.

Bérubé, Allan. Coming Out Under Fire: The History of Gay Men and Women in World War Two. Free Press, 1990.

---. "The History of Gay Bathhouses." Policing Public Sex: Queer Politics and the Future of AIDS Activism. Eds. Dangerous Bedfellows. South End Press, 1996. pp. 187-220.

Bersani, Leo. "Is the Rectum a Grave?” AIDS: Cultural Analysis, Cultural Criticism Ed. Douglas Crimp. MIT Press, 1987. pp. 197-222. 
Bersani, Leo, and Adam Phillips. Intimacies. U of Chicago P, 2008.

Blas, Zach. "Virus, Viral.” WSQ: Women's Studies Quarterly, vol. 40, no. 1, 2, Spring/Summer 2012. pp. 29-39.

Bloom, Harold. Omens of Millennium: The Gnosis of Angels, Dreams, and Resurrection. Riverhead Books, 1996.

Bogost, Ian. Alien Phenomenology, or What It's Like to Be a Thing. U of Minnesota P, 2012.

Brecht, Bertolt. Brecht on Theatre: The Development of an Aesthetic. Ed. and Trans. John Willett. Hill and Wang, 1964.

Bronski, Michael. A Queer History of the United States. Beacon Press, 2011.

Bryant, Levi R. The Democracy of Objects. Open Humanities Press, 2011.

Butler, Judith. Bodies That Matter: On the Discursive Limits of "Sex". Routledge, 1993.

Byttebier, Stephanie. “'It Doesn't Count If It's Easy': Facing Pain, Mediating Identity in Tony Kushner's Angels in America." Modern Drama, vol. 54, no. 3, Fall 2011. pp. 287-309.

Callen, Michael, Richard Berkowitz, and Richard Dworkin. "We Know Who We Are: Two Gay Men Declare War on Promiscuity.” New York Native, 8-21 Nov. 1982. pp. 24+.

Caron, David. The Nearness of Others: Searching for Tact and Contact in the Age of HIV. U of Minnesota P, 2014.

---. “Truvada Mon Amour.” The Brooklyn Quarterly, 22 Mar. 2016. http://brooklynquarterly.org/truvada-mon-amour/

Cart, Michael. "What a Wonderful World: Notes on the evolution of GLBTQ literature for Young Adults.” The Alan Review, vol. 31, no.2, Winter 2004.

Cart, Michael and Christine A. Jenkins. The Heart Has Its Reason: Young Adult Literature with Gay/Lesbian/Queer Content, 1969-2004. Scarecrow Press, 2006. 
Centers for Disease Control and Prevention. HIV Surveillance Report: Diagnoses of HIV Infection and AIDS in the United States and Dependent Areas, 2013. Vol. 25. Feb. 2015. https://www.cdc.gov/hiv/pdf/library/reports/surveillance/cdc-hiv-surveillance-report2013-vol-25.pdf

Chambers, Ross. Untimely Interventions: AIDS Writing, Testimonial, and the Rhetoric of Haunting. U of Michigan P, 2004.

Chaudhuri, Una. Staging Place: The Geography of Modern Drama. U of Michigan P, 1995.

Clum, John M. Acting Gay: Male Homosexuality in Modern Drama. Revised Ed. Columbia UP, 1994.

Cohen, Ed. Talk on the Wilde Side. Routledge, 1993.

Cohen, Peter F. "Strange Bedfellows: Writing Love and Politics in Angels in America and The Normal Heart." Journal of Medical Humanities, vol. 19, no. 2/3, 1998. pp. 197-219.

Comaroff, Jean. "Beyond Bare Life: AIDS, (Bio)Politics, and the Neoliberal Order." Public Culture, vol. 19, no. 1, Winter 2007. pp. 197-219.

Cong. Rec. 29 Mar.1950: 4527 writing.upenn.edu. (statement of Rep. Arthur Miller). http://www.writing.upenn.edu/ afilreis/50s/gays-in-govt.html

Crimp, Douglas. "How to Have Promiscuity in an Epidemic." AIDS: Cultural Analysis, Cultural Criticism Ed. Douglas Crimp. MIT Press, 1987. pp. 237-271.

Crisp, Thomas. "From Romance to Magical Realism: Limits and Possibilities in Gay Adolescent Fiction." Children's Literature in Education, vol. 40, 2009. pp. 333-348.

D’Emilio, John. “A Meaning for All Those Words: Sex, Politics, History and Larry Kramer.” We Must Love One Another Or Die: The Life and Legacy of Larry Kramer. Ed. Lawrence D. Mass. St. Martin's, 1999. pp. 73-85. 
Dean, Tim. "Mediated Intimacies: Raw Sex, Truvada, and the Biopolitics of Chemoprophylaxsis." Sexualities, vol. 18, no. 1,2, 2015, pp. 224-246.

---. Unlimited Intimacy: Reflections on the Subculture of Barebacking. U of Chicago P, 2009.

Deleuze, Gilles, and Félix Guattari. A Thousand Plateaus: Capitalism and Schizophrenia. U of Minnesota P, 1987.

Denneny, Michael. "AIDS Writing and the Creation of a Gay Culture." Confronting AIDS Through Literature: The Responsibilities of Representation. Ed. Judith Laurence Pastore. U of Illinois P, 1993. pp. 36-54.

Doyle, Laura. "Introduction: The Resistant Material." Bodies of Resistance: New Phenomenologies of Politics, Agency, and Culture. Ed. Laura Doyle. Northwestern UP, 2001. pp. xi-xxxiv.

Duran, David. “'Undetectable’ Is the New 'Negative.” POZ, 11 March 2014. https://www.poz.com/article/david-duran-25268-1687

Edelman, Lee. Homographesis. Routledge, 1994.

---. “The Mirror and the Tank: 'AIDS,' Subjectivity, and the Rhetoric of Activism.” Writing AIDS: Gay Literature, Language, and Analysis. Eds. Timothy F. Murphy and Suzanne Poirier. Columbia UP, 1993. pp. 9-38.

Elovitz, Marc and P.J. Edwards. "The D.O.H. Papers: Regulating Public Sex in New York City.” Policing Public Sex: Queer Politics and the Future of AIDS Activism. Eds. Dangerous Bedfellows. South End Press, 1996. pp. 295-316.

“The End of AIDS?” PBS NewsHour http://www.pbs.org/newshour/features/end-of-aids/ Eskridge, Jr., William N. The Case for Same-Sex Marriage. Free Press, 1996.

Esposito, Roberto. Immunitas: The Protection and Negation of Life. Trans. Zakiya Hanafi 
Polity Press, 2011.

Evenson, Laura. “'Angels' They Have Hoisted on High.” San Francisco Chronicle, 10 Oct 1994. E1, E2.

Fisher, James. "The Advantage of Controversy: Angels in America and Campus Culture Wars." Theatre Symposium, vol. 15, 2007. pp.123-132.

---. Understanding Tony Kushner. U of South Carolina P, 2008.

Fisher, Mary. My Name is Mary Fisher: A Memoir. Scribner, 1996.

Foucault, Michel. The History of Sexuality: Volume 1: An Introduction. Vintage, 1978.

Freccero, Carla. Queer/Early/Modern. Duke UP, 2006.

Freeman, Elizabeth. Time Binds: Queer Temporalities, Queer Histories. Duke UP, 2010.

Fuoss, Kirk. "A Portrait of the Adolescent as a Young Gay: The Politics of Male Homosexuality in Young Adult Fiction." Queer Words, Queer Images: Communication and the Construction of Homosexuality. Ed. R. Jeffrey Ringer. New York UP, 1994. pp. 159-174.

Galloway, Alexander R. and Eugene Thacker. The Exploit: A Theory of Networks. U of Minnesota P, 2007.

Garden, Nancy. "Brave New World.” Review of Boy Meets Boy, by David Levithan. Lambda Book Report, Mar/Apr 2004. pp. 32-33.

Geary, Adam M. Antiblack Racism and the AIDS Epidemic. Palgrave Macmillan, 2014.

Geis, Deborah R. “"The Delicate Ecology of Your Delusions': Insanity, Theatricality, and the Thresholds of Revelation in Kushner's Angels in America." Approaching the Millennium: Essays on Angels in America. Eds. Deborah R. Geis and Steven F. Kruger. U of Michigan P, 1997. pp.199-209.

Gendin, Stephen. “My Turn: Riding Bareback.” POZ, April 1997. 
https://www.poz.com/article/Riding-Bareback-12394-5736

Gendin, Stephen and Kyle McDowell. "Both Sides Now.” POZ, Nov. 1999.

https://www.poz.com/article/Both-Sides-Now-12073-2164

Gillett, James. A Grassroots History of the HIV/AIDS Epidemic in North America. Marquette Books, 2011.

Gindt, Dirk. “'Your Asshole is Hanging Outside of Your Body?': Excess, AIDS, and Shame in the Theatre of Sky Gilbert." The Use of Excess in Material Culture, 1600-2010. Ed. Julia Skelly. Ashgate, 2014. pp. 249-277.

Glitz, Michael. "Heart Still Burns." The Advocate, 24 May 2004. pp. 66-67.

Goldsmith, Francisca. Review of Boy Meets Boy, by David Levithan. School Library Journal, Sept. 2005. p. 81.

Goldstein, Bill. “Andrew Holleran: A Trilogy of Divided Lives.” Publishers Weekly, vol. 243, no. 25, 17 June 1996. pp. 42-43.

Goldstein, Richard. “Kramer’s Complaint.” Village Voice, 2 July 1985. pp. $20+$.

---. "The Implicated and the Immune: Cultural Responses to AIDS.” The Milbank Quarterly, vol. 68, Supplement 2 (Part 2), 1990. pp. 295-319.

Gould, Deborah B. 'Rock the Boat, Don't Rock the Boat, Baby: Ambivalence and the Emergence of Militant AIDS Activism." Passionate Politics: Emotions and Social Movements. Eds. Jeff Goodwin, James M. Jasper, and Francesca Polletta. U of Chicago P, 2001. pp.135-157.

---. "The Shame of Gay Pride in Early AIDS Activism." Gay Shame. Eds. David Halperin and Valerie Traub. U of Chicago P, 2009. pp. 221-255.

Gould, Robert. E. “Reassuring News About AIDS: A Doctor Tells Why You May Not Be At 
Risk.” Cosmopolitan, January 1988. pp.146+

Gross, Lexy. "Ind. could have avoided HIV outbreak, study shows." Courier-Journal, 27 July 2016. http://www.courier-journal.com/story/news/local/indiana/2016/07/27/ind-couldhave-avoided-hiv-outbreak-study-says/87621720/

Grover, Jan. “Andrew Holleran’s ‘Ground Zero': Heart Problems.” San Francisco Sentinel, 7 Oct. 1988. pp. 24+.

Halperin David M. and Valerie Traub. "Beyond Gay Pride." Gay Shame. Eds. David Halperin and Valerie Traub. U of Chicago P, 2009. pp. 3-40.

Hanson, Ellis. "Teaching Shame.” Gay Shame. Eds. David Halperin and Valerie Traub. U of Chicago P, 2009. pp. 132-164.

Harman, Graham. Guerrilla Metaphysics: Phenomenology and the Carpentry of Things. Open Court, 2005.

Hayn, Judith and Lisa Hazlett. "Connecting LGBTQ to Others Through Problem Novels: When a LGBTQ Is NOT the Main Character.” The Alan Review, vol. 36, no.1, Fall 2008.

"HIV Among Women." CDC.gov 26 Sept. 2016. https://www.cdc.gov/hiv/group/gender/women/ "HIV in the United States: At a Glance." CDC.gov. Nov. 2013. http://www.cdc.gov/hiv/library/reports/surveillance/

Hoggett, Paul. Politics, Identity, and Emotion. Routledge, 2009.

Holleran, Andrew. The Beauty of Men. William Morrow, 1996.

---. Chronicle of a Plague, Revisited: AIDS and its Aftermath. Da Capo Press, 2008.

---. "Friends at Evening." Men on Men: Best New Gay Fiction. Ed. George Stambolian. Plume, 1986. pp. 88-113.

---. Ground Zero. William Morrow, 1988. 
---. "Introduction." Introduction. The Normal Heart. New American Library, 1985. pp. 23-28.

---. Letter to Robert Prager. 25 July 1985. The collection of the GLBT Historical Society, California.

Hubbs, Nadine. "On the Uses of Shame and Gifts of a Bloodmobile: Musings From a Musical Queer Apprenticeship." Gay Shame. Eds. David Halperin and Valerie Traub. Chicago: U of Chicago P, 2009. pp. 111-116.

Huettner, Sabrina. “No Country For the Infirm': Capitalism, AIDS, and American Drama.” American Economies Eds. Eva Boesenberg, Reinhard Isensee, Martin Klepper. Universitätsverlag, Winter, 2012. pp. 261-279.

Ibáñez Carrasco, Francisco. Giving It Raw: Nearly 30 Years With AIDS. Transgress Press, 2014.

Johnson, David K. The Lavender Scare: The Cold War Persecution of Gays and Lesbians in the Federal Government. U of Chicago P, 2004.

Jones, Cleve. When We Rise: My Life in the Movement. Hachette, 2016.

Juntunen, Jacob M. "Profitable Dissents: The Mainstream Theatre of Larry Kramer and Tony Kushner as a Negotiating Force Between Emergent and Dominant Ideologies.” Dissertation, Northwestern U, 2007.

Kim, Richard. “Andrew Sullivan, Overexposed.” The Nation. 5 June 2001. https://www.thenation.com/article/andrew-sullivan-overexposed/

Knabe, Susan. "History and AIDS in Was and Angels in America." Extrapolation, vol. 49, no. 2, 2008. pp. 214-239.

Kramer, Larry. The Normal Heart and The Destiny of Me. Grove Press, 2000.

---. Reports from the Holocaust: The Story of an AIDS Activist. St. Martin's Press, 1994.

---. The Tragedy of Today's Gays. Tarcher/Penguin, 2005. 
Kushner, Tony. Angels in America. TCG, 2003.

Levithan, David. Boy Meets Boy. 10 ${ }^{\text {th }}$ anniversary ed. Ember, 2013.

Lewis, Johanna. Review of Boy Meets Boy, by David Levithan. School Library Journal, Sept. 2003. pp. 216-217.

Long, Thomas. AIDS and American Apocalypticism: The Cultural Semiotics of an Epidemic. State U of New York P. 2005.

Love, Heather. Feeling Backward: Loss and the Politics of Queer History. Harvard UP, 2007. Lupkin, Sydney. "Rogue Dentist May Have Exposed 7,000 Patients to HIV, Hepatitis." abcnews.go.com. 28 Mar. 2013. http://abcnews.go.com/Health/rogue-dentist-exposed7000-patients-hiv-hepatitis/story?id=18834611

Mason, Katherine, et al. "Locating Queer Community in Award-Winning LGBTQ-Themed Young Adult Literature.” The Alan Review vol. 39, no. 3, Summer 2012.

May, Todd. Gilles Deleuze: An Introduction. Cambridge UP, 2005.

Miller Jr., Robert L. “An Appointment with God: AIDS, Place, and Spirituality.” The Journal of Sex Research, vol. 42, no. 1, 2005. pp. 35-45.

Moore, Patrick. Beyond Shame: Reclaiming the Abandoned History of Radical Gay Sexuality. Beacon Press, 2004.

Moore, Perry. Hero. Hyperion, 2007.

“Morality, AIDS and the Bathhouses.” Editorial. The New York Times, 19 Oct 1985, p. 1.26.

Morrison, Toni. Playing in the Dark: Whiteness and the Literary Imagination. Vintage, 1992.

Muñoz, José Esteban. Cruising Utopia: the Then and There of Queer Futurity. New York UP, 2009.

"New HIV infections drop 18 percent in six years." CDC.gov 14 Feb. 2017. 
https://www.cdc.gov/nchhstp/newsroom/2017/croi-hiv-incidence-press-release.html Newtown, George. "Sex, Death, and the Drama of AIDS." The Antioch Review, vol. 47, no. 2, Spring 1989. pp. 209-222.

Pattee, Amy S. "Sexual Fantasy: The Queer Utopia of David Levithan's Boy Meets Boy." Children's Literature Association Quarterly, vol. 33, no. 1, Summer 2008. pp. 156-171. Patton, Cindy. Inventing AIDS. Routledge, 1990.

---. Sex \& Germs: The Politics of AIDS. South End Press, 1985.

“PBS NewsHour Launches Six-Part Series ‘The End of AIDS?”” pbs.org 11 July 2016. http://www.pbs.org/newshour/pressrelease/pbs-newshour-launches-six-part-series-endaids/

Pearl, Monica. AIDS Literature and Gay Identity: The Literature of Loss. Routledge, 2013.

Phelan, Shane. Sexual Strangers: Gay, Lesbians, and Dilemmas of Citizenship. Temple UP, 2001.

Piggford, George. “'In Time of Plague': AIDS and Its Significations in Hervé Guibert, Tony Kushner, and Thom Gunn.” Cultural Critique, vol. 44, Winter 2000. pp. 169-196.

Pugh, Tison. Innocence, Heterosexuality, and the Queerness of Children's Literature. Routledge, 2010.

Review of Boy Meets Boy, by David Levithan. Horn Book Magazine, Jan/Feb 2004. p. 83-84.

---. Publishers Weekly, 6 Oct 2013.

Rimmerman, Craig A. From Identity to Politics: The Lesbian and Gay Movements in the United States. Temple UP, 2002.

Rockefeller, Elsworth. "The Genre of Gender: The Emerging Canon of Transgender Inclusive YA Literature.” The Horn Book Magazine, Sept-Oct 2007. pp. 519-526. 
Savin-Williams, Ritch. “The New Gay Teen: Shunning Labels." The Gay \& Lesbian Review Worldwide, vol. 12, no. 6, Nov/Dec 2005. p. 16.

Savran, David. "Ambivalence, Utopia, and a Queer Sort of Materialism: How Angels in America Reconstructs the Nation." Approaching the Millennium: Essays on Angels in America. Eds. Deborah R. Geis and Steven F. Kruger. U of Michigan P, 1997. pp. 13-39.

---. "The Theatre of the Fabulous: An Interview with Tony Kushner." Essays on Kushner's Angels. Ed. Per Brask. Blizzard Publishing, 1996. pp. 127-154.

Saxey, Esther. Homoplot: The Coming-Out Story and Gay, Lesbian and Bisexual Identity. Peter Lang, 2008.

Sedgwick, Eve Kosofsky. Between Men: English Literature and Male Homosocial Desire. Columbia UP, 1985.

Shernoff, Michael. Without Condoms: Unprotected Sex, Gay Men, and Barebacking. Routledge, 2006.

Shilts, Randy. And The Band Played On: Politics, People, and the AIDS Epidemic. St. Martin's Press, 1988.

Sinfield, Alan. Cultural Politics-Queer Reading. U of Pennsylvania P, 1994.

---. Out on Stage: Lesbian and Gay Theatre in the Twentieth Century. Yale UP, 1999.

Smith, Matthew Wilson. “Angels in America: A Progressive Apocalypse.” Theater, vol. 29, no. 3, 1999. pp. 153-165.

Sontag, Susan. AIDS and Its Metaphors. Farrar, Straus, and Giroux, 1989.

Sullivan, Andrew. Love Undetectable: Notes on Friendship, Sex, and Survival. Vintage Books, 1998.

“Tanzania threatens to publish 'gay list.”” Deutsche Welle 18 Feb 2017. 
http://www.dw.com/en/tanzania-threatens-to-publish-gay-list/a-37616326

Tietz, Daniel. "AIDS Remains a Problem. But is it Still a Priority for the Gay Community?" Washington Post, 20 July 2012.

“A Timeline of HIV/AIDS.” aids.gov. June 2016. https://www.aids.gov/hiv-aids-basics/hiv-aids101/aids-timeline/

Trautwein, Mark. "The Death Sentence That Defined My Life." New York Times, 5 June 2011. $8(\mathrm{~L})$.

UNAIDS. “Global AIDS Epidemic Facts and Figures.” unaids.org. 2014.

Visser, Dirk. "Plagued for Their Offences: AIDS \& Theatrical Representation.” Interfaces, vol. 26, 2006-07. pp. 175-192.

Warner, Michael. Publics and Counterpublics. Zone Books, 2005.

---. The Trouble with Normal. Free Press, 1999.

Watney, Simon. Policing Desire: Pornography, AIDS, and the Media. U of Minnesota P, 1987.

Watson, Dwight. "Exploring Social Connectivity through the Use of Adolescent Queer Literature.” American Journal of Sexuality Education, vol. 5, 2010. pp. 268-289.

Whitman, Walt. Leaves of Grass and Other Writings. Ed. Michael Moon. W.W. Norton, 2002.

Williams, Raymond. Marxism and Literature. Oxford UP, 1977.

Woods, Gregory. A History of Gay Literature: The Male Tradition. Yale UP, 1998. 